\title{
The Zintl-Klemm Concept Applied to Cations in Oxides. II. The Structures of Silicates
}

\author{
David Santamaría-Pérez ${ }^{1} \cdot$ Angel Vegas $^{1}(\varangle) \cdot$ Friedrich Liebau $^{2}(\varangle)$ \\ ${ }^{1}$ Instituto de Química Física "Rocasolano", CSIC, C/Serrano 119, 28006 Madrid, Spain \\ avegas@iqfr.csic.es \\ ${ }^{2}$ Institut für Geowissenschaften, Christian-Albrechts Universität zu Kiel, \\ Olshausenstrasse 40, 24098 Kiel, Germany \\ liebau@min.uni-kiel.de
}

1 Introduction

2 The Crystal Chemical Formula Notation for Silicates . . . . . . . . . . . 124

3 The Zintl-Klemm Concept . . . . . . . . . . . . . . . . . 126

3.1 The Pseudo-Formula Notation for Zintl Phases . . . . . . . . . . . . 128

4 The Main Group Elements and their Oxides . . . . . . . . . . . . 128

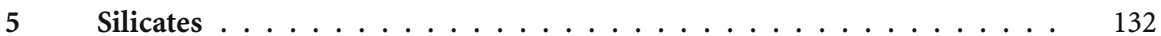

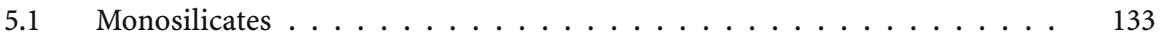

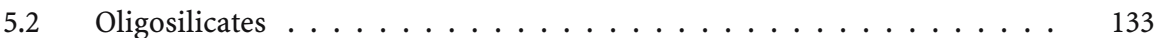

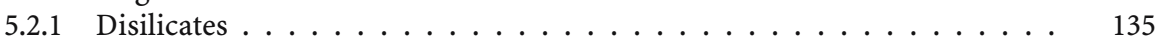

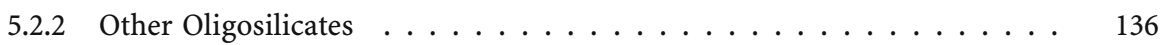

5.3 Ring Silicates . . . . . . . . . . . . . . . . . . . . . . . . 138

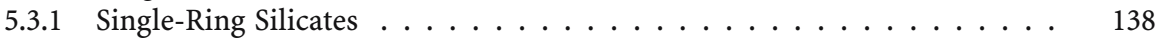

5.3 .2 Double-Ring Silicates . . . . . . . . . . . . . . . . . . . . . 141

5.4 Chain Silicates . . . . . . . . . . . . . . . . . . . . 143

5.4 .1 Single-Chain Silicates . . . . . . . . . . . . . . . . . . . . . . . . . . . . . . . . . . . . .

5.4 .2 Double-Chain Silicates . . . . . . . . . . . . . . . . . . . . . 148

5.5 Layer Silicates . . . . . . . . . . . . . . . . . . . . . . . . . . . 149

5.5.1 Single-Layer Silicates . . . . . . . . . . . . . . . . . . . . . . . . . . . . 149

5.5 .2 Double-Layer Silicates . . . . . . . . . . . . . . . . . . . . . . . 154

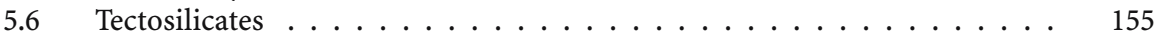

5.6.1 Subdivision of Tetrahedron Frameworks According to Connectivity . . . . 155

5.6 .2 Fully Linked Tectosilicates . . . . . . . . . . . . . . . . . . . . . . . 155

5.6 .3 Underlinked Tectosilicates . . . . . . . . . . . . . . . . . . . . 160

6 Si Atoms in Octahedral Coordination . . . . . . . . . . . . . . 161

$7 \quad$ Concluding Remarks . . . . . . . . . . . . . . . . . . . 164

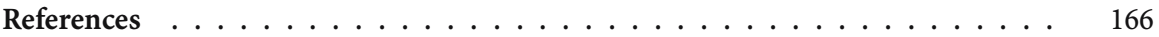

Abstract The structures of ternary and quaternary silicates are revisited on the basis of the Zintl-Klemm concept and the Pearson's generalised octet rule. The three-dimensional skeletons formed by the $\mathrm{Si}$ atoms can be interpreted as if the $\mathrm{Si}$ atoms were behaving as 
Zintl polyanions, adopting the structure of either main-group elements or Zintl polyanions showing the same connectivity. The $\mathrm{O}$ atoms are then located close to both, the hypothetical two-electron bonds and the lone pairs, giving rise to a tetrahedral coordination. In some silicates, the $\mathrm{Si}$ atoms clearly show an amphoteric character so that some $\mathrm{Si}$ atoms act as donors (bases) adopting an octahedral coordination, whereas others behave as acceptors (acid), adopting a tetrahedral coordination. Although the octahedral coordination seems to be favoured by the application of pressure, the results reported here indicate that the coordination sphere of silicon is not a function of the assumed ionic radius of the $\mathrm{Si}^{4+}$ cations but it depends on the nature of the other cations accompanying them in the structure.

Keywords Silicates - Structures · Zintl-Klemm concept · Cation arrays · Zintl phases

\author{
Abbreviations \\ $\mathrm{CN}$ Coordination Number \\ ELF electron localisation function \\ HP high pressure \\ HT high temperature \\ NNM non-nuclear maxima \\ $\mathrm{P} \quad$ pressure \\ PSE Periodic Table of Elements \\ $\mathrm{T}$ temperature \\ VSEPR valence shell electron pair repulsion
}

\title{
Introduction
}

The chemistry of silica and silicates has been widely studied. Silicates are the most interesting and the most complicated class of minerals. Approximately $30 \%$ of all minerals are silicates and some geoscientists estimate that $90 \%$ of the Earth's crust is made up of silicates. They also play an important role in daily life. Thus, silicates are present in raw materials and several industrial products such as glass, concrete and many ceramic materials. Their widespread application is due to the large variability of their properties and this, in turn, is due to the very large number of different silicate phases and the diversity of their structures.

Concerning the structural chemistry of silicates, the Inorganic Crystal Structure Database (ICSD), release 2004, contains 3192 entries of ternary and quaternary silicates. Silicates have often been described on the basis of the ionic model, i.e. a dense packing of $\mathrm{O}^{2-}$ anions in which $\mathrm{Si}^{4+}$ cations seem to fit into interstitial tetrahedral voids [1]. However, several experimental studies of the electron density distribution clearly indicate that the $\mathrm{Si}-\mathrm{O}$ bond has a considerable covalent character [2]. Thus, a model which considers silicates as formed by either isolated or condensated $\left[\mathrm{SiO}_{4}\right]$ tetrahedra seems 
to be more appropriate. Following this descriptive model, silicates have been classified into monosilicates, oligosilicates, ring silicates, chain silicates, layer silicates and tectosilicates according to the type of polyanion present in the structure. A richly illustrated survey of the structures of crystalline silicates is the book "Structural Chemistry of Silicates" which contains an extensive study of the bonding and structures of these compounds [3]. In it, the structures are classified and described following a criterion of increasing complexity of the silicate polyanions but it should be pointed out that the reasons why these polyanions adopt a given structure are far from being explained. This is the reason why the so-called "rich variety" of condensated silicate polyanions has been considered, in many instances, as "capricious".

An early attempt to correlate, in tetrahedral structures, the connection between the tetrahedra and composition was carried out by Parthé \& Engel [4]. Later, Parthé \& Chabot [5] applied the Zintl-Klemm concept $[6,7]$ to deduce the connectivity in structures with anionic tetrahedron complexes of the general formula $C_{m} C_{m^{\prime}}^{\prime} A_{n}$. From valence-electron criteria they deduced expressions which allow for the prediction of tetrahedral sharing numbers as well as the formation of $C-C^{\prime}$ and $A-A$ bonds. Although they were able to predict connectivity between $C A_{4}$ and $C^{\prime} A_{4}$ tetrahedra, the 3D frameworks remained unexplained and they were not related to other simple or elemental structures.

In a more recent paper [8], the Zintl-Klemm concept [6,7] and Pearson's generalised octet rule [9] were successfully applied to 94 ternary aluminates, a family of compounds which, like silicates, also form condensated polyanions of tetrahedrally coordinated $\mathrm{Al}$ atoms. These two old concepts will help us to understand both the coordination spheres of the Si atoms and the threedimensional arrays of their structures. Because some readers will not be familiar with these concepts, they will be briefly described in Sect. 3.

When this concept was applied to describe the Al-frameworks in aluminates, it was seen that, in aluminates of highly electropositive metals such as alkali, alkaline-earth and rare earth metals, the $\mathrm{Al}$ atoms form 3D skeletons which can be interpreted as if the $\mathrm{Al}$ atoms would behave as Zintl polyanions with hypothetical $\mathrm{Al}-\mathrm{Al}$ bonds. These $\mathrm{Al}$ skeletons adopt the structure of either main group elements or Zintl polyanions showing the same connectivity. The $\mathrm{O}$ atoms are then docked close to both, the hypothetical $\mathrm{Al}-\mathrm{Al}$ two-electron bonds and the lone electron pairs, giving rise to tetrahedral coordination of Al. On the contrary, when less electropositive (more electronegative) species coexist with aluminium in the oxide, the $\mathrm{Al}$ atoms do not behave as a Zintl polyanion anymore and adopt an octahedral coordination. Moreover, in some instances, the $\mathrm{Al}$ atoms exhibit their amphoteric character by which some of them act as electron donors towards other (acidic) Al atoms which behave as Zintl polyanions. In these cases, both types of coordination polyhedra, octahedra (donors) and tetrahedra (acceptors) coexist in the structure. 
In the present work, our aim is to extend this study to some ternary and quaternary silicates. The Si subarray will be analysed in the light of both, the Zintl-Klemm concept [6,7] and Pearson's generalised octet rule [9]. It is well known that aluminates and silicates present many structural similarities. So, the principles applied to aluminates will be extended here to the structures observed in silicates, in order to provide an alternative view which puts all these apparently capricious structures on a common basis. Although we have carried out a systematic study of the structures of ternary and quaternary silicates, our aim is not to present a comprehensive study but rather to analyse some selected examples in the light of the Zintl-Klemm concept to demonstrate its applicability. To assist the reader in applying these principles to any other silicate structure, a more extended survey of silicates is given in Tables 3-7.

\section{2}

\section{The Crystal Chemical Formula Notation for Silicates}

Throughout this article, when silicates are described, the term "coordination" will be used to denote how $\mathbf{X}^{1}$ anions (usually oxygen atoms) surround a given cation, and the term "connectivity" will be used to express, in particular, the contacts between tetrahedrally coordinated cations ( $\mathrm{T}^{1}$ atoms) which are connected by a bridging oxygen forming $\mathrm{Si}-\mathrm{O}-\mathrm{Si}$ bonds. When the imaginary $\mathrm{Si}$ atom skeleton of a silicate structure is described, the term $\mathrm{Si}-\mathrm{Si}$ will be used to denote the link between two Si atoms that in the actual silicate represents a $\mathrm{Si}-\mathrm{O}-\mathrm{Si}$ bond. It will be seen below that for many silicates the Si atom skeleton is topologically very similar to the structures of corresponding, existing or hypothetical, Zintl phases in which the Si-Si link of the skeleton is replaced by a real $\mathrm{Si}-\mathrm{Si}$ bond.

Silicates will be described following an increasing order of structural complexity. We will begin with monosilicates, passing to oligosilicates, ring silicates, chain silicates, layer silicates to end with tectosilicates, most of which are quaternary compounds where silicon, together with other $\mathbf{T}$ atoms, like $\mathrm{B}, \mathrm{Be}, \mathrm{Al}$, etc. and oxygen atoms are forming the tetrahedral frameworks. All cations which, together with oxygen or other anions, are forming these tetrahedral frameworks will be denoted by the symbol $\mathrm{T}$ and consequently, the skeleton formed by the connected $\mathbf{T}$ atoms will be denoted as the $\mathbf{T}$ atom framework or $\mathbf{T}$ atom skeleton. Because the Zintl-Klemm concept establishes

\footnotetext{
${ }^{1}$ Following a recent recommendation to write chemical formulas containing structural information [10], in this paper distinction is made between the usual element symbols such as $\mathrm{Si}, \mathrm{Al}, \mathrm{O}, \mathrm{Cl}$, etc. (given as normal face Latin letters) and structure-site symbols (given as boldface Latin letters) such as $\mathbf{T}$ for tetrahedrally coordinated cations, $\mathbf{A}$ for cations without regard to their coordination number, $\mathbf{X}$ and $\mathbf{Y}$ for monoatomic anions, $\mathbf{Z}$ for polyatomic anions, and $\mathbf{M}$ for molecules such as $\mathrm{H}_{2} \mathrm{O}, \mathrm{CO}_{2}$, etc.
} 
the relationship between the connectivity of the atoms and their chemical properties, a knowledge of the crystal structure of the compound under consideration is required. Crystal chemical formulas are very efficient short-hand descriptions of both, chemical composition and structure of a substance. The crystal chemical formulas used in this paper are those recommended by the Commission on Crystallographic Nomenclature of the International Union of Crystallography [11].

Rather than giving the complete structural formula of a general inorganic compound, the formula notation shall be explained here for two typical silicates:

- Tremolite is an amphibole of chemical composition $\mathrm{Ca}_{2} \mathrm{Mg}_{5}\left[\mathrm{Si}_{4} \mathrm{O}_{11}\right]_{2}$ $(\mathrm{OH})_{2}$ [12]. Its main structural features can be given as $\mathrm{Ca}_{2}^{[8]} \mathrm{Mg}_{5}^{[6]}\{\boldsymbol{u} \boldsymbol{B}, 2$, $\left.2_{\infty}^{1}\right\}\left[\mathrm{Si}_{2}^{\lceil 1 ; 3]} \mathrm{Si}_{2}^{\lceil 1 ; 2\rfloor} \mathrm{O}_{11}\right]_{2}(\mathrm{OH})_{2}$.

- The structure of turkestanite, $\mathrm{K}_{<1}(\mathrm{Na}, \mathrm{Ca})_{2} \mathrm{Th}\left[\mathrm{Si}_{8} \mathrm{O}_{20}\right]$, [13] can be written as $\mathrm{K}_{<1}^{[12]}(\mathrm{Na}, \mathrm{Ca})_{2}^{[8]} \mathrm{Th}^{[8]}\{\boldsymbol{u} \boldsymbol{B}, 4,2 \boldsymbol{r}\}\left[\mathrm{Si}_{8}^{[1 ; 3]} \mathrm{O}_{20}\right]$.

These two specific formulas can be generalised into the following crystal chemical formula of silicates $\mathbf{A}_{a}^{[C N]} \mathbf{A}_{a^{\prime}}^{\prime[C N]} \ldots\left\{\boldsymbol{B}, \boldsymbol{P}, \boldsymbol{M}_{\infty}^{\mathrm{D}}\right\}\left[\mathbf{T}_{t}^{[l ; s]} \mathbf{T}_{t^{\prime}}^{\prime[l s\rfloor} \ldots \mathbf{X}_{x}, \mathbf{X}_{x^{\prime}}^{\prime}\right]$ $\mathbf{Y}_{y} \mathbf{Z}_{z}\left(\mathbf{M}_{m}\right)$.

In this formula the silicate anion is written within square brackets and its constitution within the preceding curly brackets. Cations not belonging to the silicate anion precede, and non-silicate anions follow the information on the silicate anion. If necessary, coordination numbers can be written, within square brackets, as trailing superscripts to the element symbols. Usually only four-coordinated cations ( $\mathrm{T}$ cations) are considered as part of a silicate anion. Therefore, it is unnecessary to add the coordination numbers as a trailing superscript to the $\mathrm{T}$ cations.

The information on the constitution of the silicate anion contains (i) the branchedness $\boldsymbol{B}$ which may be unbranched $(\boldsymbol{u} \boldsymbol{B})$, open-branched $(\boldsymbol{o B})$, loopbranched $(\boldsymbol{l} \boldsymbol{B})$, open- as well as loop-branched $(\boldsymbol{o l} \boldsymbol{B})$ or hybrid $(\boldsymbol{h} \boldsymbol{B})$; (ii) the periodicity, i.e. the number of tetrahedra in the identity period of the fundamental chain $\left(\boldsymbol{P}^{\mathrm{C}}\right)$ or fundamental $\operatorname{ring}\left(\boldsymbol{P}^{\mathrm{R}}\right)$ from which the silicate anion can be generated by successive linkage; (iii) the multiplicity $\boldsymbol{M}$ of the silicate anion; and (iv) its dimensionality $D$ which is the number of dimensions in which the silicate anion has infinite extension. Oligoanions and rings, both having $D=0$, can be distinguished as $t$ and $r$ (for terminated and ring-shaped anions, respectively).

The tetrahedrally coordinated $\mathrm{T}$ cations forming, together with the $\mathrm{X}$ anions, the silicate anions, can be characterised by two parameters, the linkedness $(l)$ and the connectedness $(s)$. The linkedness $(l)$ expresses the number of $\mathbf{X}$ atoms (usually oxygen and only in rare cases, nitrogen) shared with each adjacent $\mathrm{T}$ cation. Thus, $l=0$ for isolated tetrahedra, $l=1$ for cornersharing tetrahedra and $l=2$ for edge-sharing tetrahedra. The connectedness $(s)$ accounts for the number of adjacent $\mathrm{T}$ cations with which a given $\mathrm{T}$ cation 
shares common $\mathrm{X}$ atoms. Thus, for a corner-connected network, $s$ is the number of corners shared by a given $\left[\mathrm{SiO}_{4}\right]$ tetrahedron. It is the value of $\boldsymbol{s}$ which is most relevant in connection with the Zintl-Klemm concept. The maximum possible value of $s$ is 4 for a $\mathrm{Si}$ or $\Psi$-Si atom, 3 for a P or $\Psi$-P atom, 2 for $\mathrm{S}$ or $\Psi$-S and 1 for $\Psi$-Cl. For more detailed information on the parameters used for the formula notation see [3].

For silicate anions of finite extension $(D=0)$, the total number of $\mathbf{T}$ and $\mathbf{X}$ atoms ( $\sum t$ and $\sum x$ respectively), to be given between the square brackets of the crystal chemical formula, are equal to the numbers of these atoms in the anion. For silicate chains $(D=1), \sum t$ is the number of $\mathbf{T}$ atoms in one identity period of the chain. For silicate anions with $D>1$, the numbers of atoms are usually chosen in such a way that $\sum t$ is the smallest multiple of the $\mathbf{T}$ atoms in the period of its fundamental chain for which $\sum x$ is an integer.

According to this information, the structural formula of tremolite given above indicates that its silicate anion is an unbranched zweier double chain in which half of the Si atoms are 2-connected and the other half are 3-connected. In analogy, the formula given for turkestanite indicates that its silicate anion is an unbranched vierer double ring in which all its Si atoms are 3-connected.

\section{3}

\section{The Zintl-Klemm Concept}

The Zintl concept [6], later extended by Klemm [7], was formulated in the 1930s and has been considered by Hoffmann [14] as "the single most important theoretical concept in solid-state chemistry of the last century". It accounts for the structural and bonding features in the so-called Zintl phases $\left(A_{a} X_{x}\right)$ which are combinations of very electropositive metals (alkali, alkaline earth and rare earth metals) $(A)$ with the main-group elements $(X)$. The Zintl concept interprets the structure of these compounds as if the $A$ atoms transfer their valence electrons to the $X$ atoms. The $X$ atoms, far from being individual anions, then form polyanionic skeletons in which they are bonded by directed, covalent $X-X$ bonds. These bonds are formed by all the valence electrons, i.e., their own electrons plus those transferred from the $A$ atoms, and the number of bonds formed obey the $8-N$ rule ( $N$ being the number of valence electrons of the $X$ atom). In other words, the $X$ atoms tend to complete the octet in their valence shell. When heterogeneous $X$ species are formed, then the $X$ skeleton can be explained by the generalised octet rule [9].

Klemm [7] proposed the pseudo-atom concept for the charged $X^{n-}$ atom that would adopt a structure characteristic of the isoelectronic main group element. To illustrate the Zintl-Klemm concept, we will consider the compound $\mathrm{NaSi}$. In this compound, each $\mathrm{Na}$ atom would transfer one valence electron to a Si atom converting it structurally into a pseudo-P atom $(\Psi-\mathrm{P})$. 
For this reason, in $\mathrm{NaSi}$, the $\mathrm{Si}^{-}$anions form $\left[\mathrm{Si}_{4}\right]^{4-}$ tetrahedra, similar to the molecules of $\mathrm{P}_{4}$. The combination of Zintl's original concept and Klemm's pseudo-atom description, is called the Zintl-Klemm concept. Throughout this article, we will use the prefix $\Psi$ to denote a pseudo-atom. Thus, taking again $\mathrm{NaSi}$ as an example, the $\mathrm{Si}^{-}$anion can be denoted as $\Psi$-P.

It should be emphasised that, in the Zintl phases, two types of bonds co-exist. On one hand, the $A-X$ interaction is assumed to be almost completely ionic. On the other hand, a directed, covalent bond is formed between the $X$ atoms, giving rise to the formation of $X_{y}^{n-}$ polyanions. As said by Schäfer [15], "ionic and covalent bonds in intermetallic phases were a matter of course for Zintl". Like in other structures of the main group elements, such as Si, P, S, As, etc., the $X$ atoms are bonded by directed, two-centre, two-electron bonds. In the same manner, the electrons not involved in bonds are located in non-bonding regions forming the so-called lone electron pairs. These lone electron pairs, together with the bonding electron pairs, normally form tetrahedral arrangements as has been shown in an electron density study on the $S_{8}$ molecule [16]. Also, theoretical calculations of the Electron Localisation Function (ELF) carried out for $\mathrm{CaAl}_{2} \mathrm{Si}_{2}$ [17] and for the butterfly-shaped $\mathrm{Si}_{4}^{6-}$ polyanion [18] reveal that occupied bonding and nonbonding states are always centred at $X$ atoms. ELF calculations clearly show that the charge is localised in both, the bonding and the lone pair regions. The reader can find additional information concerning theoretical calculations and bonding aspects on the Zintl phases in $[18,19]$.

Another aspect to be dealt with here is to define which elements are capable of forming Zintl polyanions. In Table 1, part of the Periodic Table of Elements (PSE) with the elements near the Zintl border are presented. This line separates the metametals (Group 13 elements) from the semimetals and semiconductors which are the most common components of the Zintl phases. However, other elements at the left of this Zintl line, like $\mathrm{Cd}, \mathrm{Ag}, \mathrm{Al}, \mathrm{Ga}$, In and $\mathrm{Tl}$, are also susceptible to forming Zintl polyanions. Comprehensive reviews of the work reported on such compounds can be found in $[20,21]$.

Table 1 Partial representation of the Periodic Table showing the Zintl border which is represented by the double vertical line which separates the Groups 13 and 14

\begin{tabular}{|c|c|c|c|c|c|}
\hline 11 & 12 & 13 & 14 & 15 & 16 \\
\hline & & $\mathrm{Al}$ & $\mathrm{Si}$ & $\mathrm{P}$ & \\
\hline $\mathrm{Cu}$ & $\mathrm{Zn}$ & $\mathrm{Ga}$ & $\mathrm{Ge}$ & As & $\mathrm{Se}$ \\
\hline $\mathrm{Ag}$ & $\mathrm{Cd}$ & In & Sn & $\mathrm{Sb}$ & $\mathrm{Te}$ \\
\hline $\mathrm{Au}$ & $\mathrm{Hg}$ & $\mathrm{Tl}$ & $\mathrm{Pb}$ & $\mathrm{Bi}$ & Po \\
\hline
\end{tabular}




\section{1}

\section{The Pseudo-Formula Notation for Zintl Phases}

Throughout this article, the term pseudo-formula $\left(\Psi-\mathrm{Si}_{k} \mathrm{P}_{l} \mathrm{~S}_{m} \mathrm{Cl}_{n}\right)$ will be used to denote the number of atoms which have been converted into each kind of $\Psi$-atom by acceptance of electrons from the more electropositive atoms. This $\Psi$-atom formula can be easily derived from the silicate formula by replacing each $\mathbf{T}^{\lceil 1 ; 4\rfloor}, \mathbf{T}^{\lceil 1 ; 3\rfloor}, \ldots, \mathbf{T}^{\lceil 1 ; 0\rfloor}$ atom by a $\Psi$-Si, $\Psi$-P, ..., $\Psi$-Ar atom, respectively.

\section{4}

\section{The Main Group Elements and their 0xides}

A common structural feature of the oxides of the main group elements is that they maintain the structure of either (i) the parent element; (ii) an element of its own group or; (iii) Zintl polyanions isoelectronic with them. The oxides are summarised in Table 2 together with the elemental structures recognisable in them. Although the reader can get an extensive insight into this phenomenon by examining Table 2, we will briefly describe some examples which will help to understand the behaviour of the silicate polyanions described below.

The best-known examples are the different polymorphs of $\mathrm{SiO}_{2}$. Thus, cristobalite and the related compounds $\mathrm{GeO}_{2}, \mathrm{BPO}_{4}, \mathrm{BeSO}_{4}$ and the high temperature (HT) polymorph of $\mathrm{ZnSO}_{4}$, all of them have a cationic array identical to either, the elements (diamond-like $\mathrm{Si}$ and $\mathrm{Ge}$ ) or the corresponding zincblende-like (sphalerite-like) binary compounds $\mathrm{BP}, \mathrm{BeS}$ and $\mathrm{ZnS}$. In tridymite, the Si atoms adopt the same structure as lonsdaleite (sometimes called hexagonal diamond) and hexagonal silicon. The structure of quartz, adopted also by $\mathrm{GeO}_{2}, \mathrm{CO}_{2}$ under pressure [22], $\mathrm{BPO}_{4}$ and $\mathrm{AlPO}_{4}$, has a cation array whose structure is identical to that of the Si-rich phase $\mathrm{CrSi}_{2}$ [23] and also to the cinnabar-like structure of the high-pressure phase of $\mathrm{ZnTe}$ [24]. Both structures are represented in Fig. 1. As pointed out by Wells [[25], p 131], the Si-subarray of keatite corresponds to the high pressure (HP) phase $\gamma$-Ge [26]. In stishovite, a $\mathrm{HP}$ phase of $\mathrm{SiO}_{2}$ [27], and in the isostructural compounds $\mathrm{GeO}_{2}, \mathrm{SnO}_{2}$ and $\beta-\mathrm{PbO}_{2}$, the cations adopt the structure of an element of their Group, the HP phase $\gamma$-Sn [28]. Finally, the similarities between the Si array in both, the Zintl phase $\mathrm{K}_{8} \mathrm{Si}_{46}$ [29] and the silica-framework of the microporous mineral melanophlogite have also been pointed out [30].

An important aspect of all these structures, is the location of the $\mathrm{O}$ atoms. It is well known that in all the elemental structures just described (with the exception of $\gamma-\mathrm{Sn}$ ), the Group 14 atoms are linked by directed, two-centre, 
Table 2 List of binary oxides of the main group elements whose cation subarray structures coincide topologically either with those of the elements of the same group or with Zintl polyanions showing the same connectivity. In the case of silica polymorphs, some isostructural ternary oxides have been included because they also maintain the structures of their respective alloys

\begin{tabular}{|c|c|c|c|}
\hline $\begin{array}{l}\text { Oxides preserving } \\
\text { the elemental structures }\end{array}$ & Ref. & $\begin{array}{l}\text { Elemental or } \\
\text { alloy structures }\end{array}$ & Ref. \\
\hline $\mathrm{SiO}_{2}$ (cristobalite) & [119] & & \\
\hline $\mathrm{GeO}_{2}$ & [120] & Si (diamond) & [125] \\
\hline $\mathrm{BPO}_{4}$ & [121] & BP & [126] \\
\hline $\mathrm{AlPO}_{4}$ & {$[122]$} & $\mathrm{BeS}$ & [127] \\
\hline $\mathrm{BeSO}_{4}$ & [123] & ZnS (blende) & [128] \\
\hline $\mathrm{ZnSO}_{4}(\mathrm{HT})$ & [124] & & \\
\hline $\mathrm{SiO}_{2}$ (tridymite) & [129] & $\mathrm{C}$ & [131] \\
\hline $\mathrm{AlPO}_{4}$ & [130] & Si (hexagonal) & [132] \\
\hline $\mathrm{SiO}_{2}$ (quartz) & [133] & & \\
\hline $\mathrm{GeO}_{2}$ & [134] & & \\
\hline $\mathrm{CO}_{2}$ & [135] & $\mathrm{CrSi}_{2}$ & [139] \\
\hline $\mathrm{BPO}_{4}$ & [136] & $\mathrm{ZnTe}(\mathrm{HP})$ & [140] \\
\hline $\mathrm{AlPO}_{4}$ & [137] & & \\
\hline $\mathrm{FePO}_{4}$ & [138] & & \\
\hline $\mathrm{SiO}_{2}$ (keatite) & [141] & $\gamma-\mathrm{Ge}(\mathrm{HP})$ & [142] \\
\hline $\mathrm{SiO}_{2}$ (stishovite) & [143] & & \\
\hline $\mathrm{GeO}_{2}$ & [144] & $\gamma-\mathrm{Sn}(\mathrm{HP})$ & [146] \\
\hline $\mathrm{SnO}_{2}$ & [144] & & \\
\hline$\beta-\mathrm{PbO}_{2}$ & [145] & & \\
\hline Melanophlogite (silica clathrate) & [147] & $\mathrm{K}_{4} \mathrm{Si}_{23}$ & [148] \\
\hline $\mathrm{AlPO}_{4} \cdot 2 \mathrm{H}_{2} \mathrm{O}$ (metavariscite) & [149] & $\mathrm{CrB}_{4}$ & [150] \\
\hline & & $\beta-\mathrm{BeO}$ & [151] \\
\hline $\mathrm{AlPO}_{4} \cdot 2 \mathrm{H}_{2} \mathrm{O}$ (variscite) & [152] & Si (HP)- related & [153] \\
\hline $\mathrm{P}_{4} \mathrm{O}_{6}$ & [154] & & \\
\hline $\mathrm{P}_{4} \mathrm{O}_{8}$ & [155] & & \\
\hline $\mathrm{P}_{4} \mathrm{O}_{9}$ & [156] & & \\
\hline $\mathrm{P}_{4} \mathrm{O}_{10}$ & [157] & $\mathrm{P}_{4}$ (molecules) & [161] \\
\hline $\mathrm{As}_{4} \mathrm{O}_{6}$ & [158] & & \\
\hline $\mathrm{Sb}_{4} \mathrm{O}_{6}$ & [159] & & \\
\hline $\mathrm{Sb}_{4} \mathrm{O}_{10}$ & [161] & & \\
\hline \multirow[t]{4}{*}{$\mathrm{P}_{2} \mathrm{O}_{5}$} & \multirow[t]{4}{*}{ [162] } & $\mathrm{CaSi}_{2}(\mathrm{HP})$ & [163] \\
\hline & & $\mathrm{SrSi}_{2}(\mathrm{HP})$ & [163] \\
\hline & & $\mathrm{BaGe}_{2}$ & [164] \\
\hline & & $\mathrm{ThSi}_{2}$ & [165] \\
\hline $\mathrm{P}_{2} \mathrm{O}_{5}$ & [166] & As (layers) & [168] \\
\hline $\mathrm{As}_{2} \mathrm{O}_{3}$ & [167] & $\mathrm{CaSi}_{2}$ & [169] \\
\hline
\end{tabular}

Continued on next page 
Table 2 (continued)

Oxides preserving the elemental structures
Ref. Elemental or alloy structures
Ref.

[173] Bi

[174]

[178]

[179]

[180]

S (chains) asbestos-like

Se

$\mathrm{Te}$

[181]

[182]

[183]

[184] $\mathrm{S}_{3}$ (molecule)

[185]

[186] $\mathrm{S}_{4}$ (molecule)

[188] Te (HP)

[189]

[190]

[192]

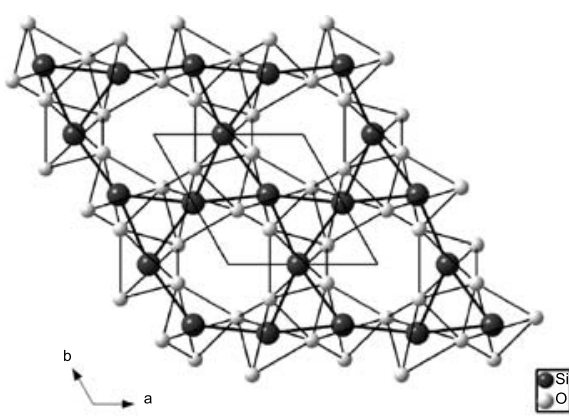

a

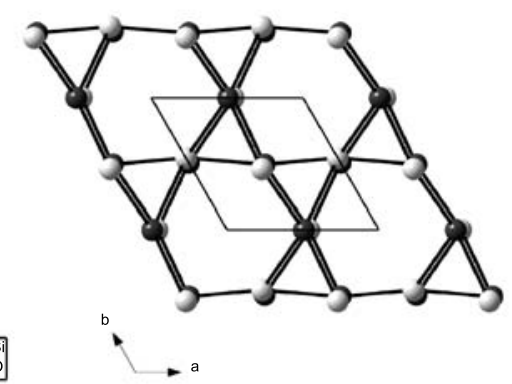

b

Fig. 1 a Projection of quartz structure in which the $\mathrm{Si}-\mathrm{Si}$ contacts have been drawn with thick lines to show its similarity with $\mathbf{b}$ the structure of HP-ZnTe

two-electron bonds and, when an oxide is formed from the element, the $\mathrm{O}$ atoms are always located close to the midpoints of these bonds, maintaining the topology of the elemental structure and producing thus a tetrahedral coordination of the $\mathrm{O}$ atoms around the $\mathrm{T}$ atoms.

Regarding the Group 15 elements, this behaviour is kept. Thus, the tetrahedral structure of the $\mathrm{P}_{4}$ molecule is preserved in the oxides $\mathrm{P}_{4} \mathrm{O}_{6}, \mathrm{P}_{4} \mathrm{O}_{8}$, $\mathrm{P}_{4} \mathrm{O}_{9}, \mathrm{P}_{4} \mathrm{O}_{10}, \mathrm{As}_{4} \mathrm{O}_{6}$ (arsenolite), $\mathrm{Sb}_{4} \mathrm{O}_{6}$ and $\mathrm{Sb}_{4} \mathrm{O}_{10}$. This behaviour had already been pointed out by Addison in 1965 [31]. Some of these structures are presented in Fig. 2. 


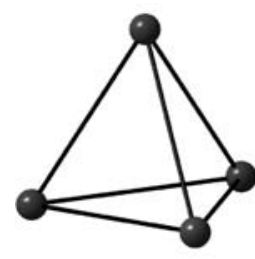

a

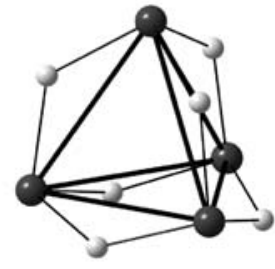

b

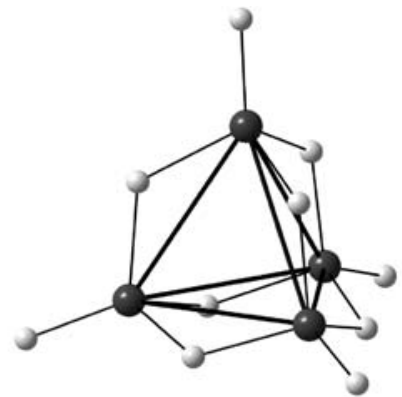

c

Fig. 2 The structure of the $\mathrm{P}_{4}$ molecule to show how it is maintained in the $\mathrm{P}_{4} \mathrm{O}_{6}$ and $\mathrm{P}_{4} \mathrm{O}_{10}$ oxides

The same occurs with a second $\mathrm{P}_{4} \mathrm{O}_{10}$ phase, o- $\mathrm{P}_{4} \mathrm{O}_{10}$ (Fdd2), in which the $\left[\mathrm{PO}_{4}\right]$ tetrahedra form a 3-dimensional framework [32] whose $\mathrm{P}$ atom skeleton is similar to the arrangement of the $\mathrm{Si}$ atoms $(\Psi-\mathrm{P})$ in the Zintl phase $\mathrm{SrSi}_{2}$. In the same manner, both, a third phase of $\mathrm{P}_{4} \mathrm{O}_{10}$ (Pnma) [33] and a second phase of $\mathrm{As}_{4} \mathrm{O}_{6}$ (claudetite) [34] maintain the layer structure of elemental As.

Also in these compounds, when the oxide is formed, the $\mathrm{O}$ atoms are located close to both, the $\mathrm{P}-\mathrm{P}$ bonds and the lone pairs of the $\mathrm{P}(\mathrm{As})$ atoms. In this way, in the pentavalent oxides, the tetrahedral coordination is achieved.

At present we cannot give a completely rigorous explanation of why the basic geometric features of the structures of the elements are maintained in binary oxides although the distances between the element atoms are increased considerably. If we take the molecule of $\mathrm{P}_{4} \mathrm{O}_{6}$ as a reference, it is clear that the insertion of oxygen into the $\mathrm{P}_{4}$ molecule leads to the formation of strong $\mathrm{P}-\mathrm{O}$ covalent bonds, and thereby preventing the formation of significant phosphorus-phosphorus bonding interactions. A possible explanation of that coincidence could be that, in spite of the strong $\mathrm{P}-\mathrm{O}$ bonds, some residual $\mathrm{P}-\mathrm{P}$ interaction persists. However, this would require the potential energy surface to be very flat so that the very small bonding interaction energy could lead to such a preferred geometric arrangement. In this sense, theoretical calculations, including a topological analysis of the electron density, would be desirable in order to detect possible critical points between the $\mathrm{P}$ atoms. An alternative explanation is that the tetrahedral arrangement of the $\mathrm{P}$ atoms could reflect a minimum energy situation for two quite unrelated electronic situations. It is well known that certain polyhedral arrangements on the surface of a sphere are solutions both to the minimisation of repulsion and covering problems. Therefore, the observation of a tetrahedral arrangement in both cases may not have related electronic causes. Indeed they may have quite contradictory origins. Taking the VSEPR theory as a guide, the tetrahedral coordination minimises repulsions between the ligands ( $\mathrm{O}$ atoms) 
in phosphate and sulphate anions but at the same time it occurs in clusters such as $\mathrm{P}_{4}$ and $\mathrm{B}_{4} \mathrm{Cl}_{4}$, where significant element-element bonding is present. The tetrahedral arrangement of the phosphorus or boron atoms enables four atoms on the surface of a sphere to overlap and share electron density in the most efficient way. The tetrahedral arrangement also minimises the repulsions between four equal atoms on the surface of a sphere. Therefore, the same polyhedral geometry represents the most favoured solution for two quite different electronic situations. The octahedron and icosahedron display similar dual geometric solutions to the covering and repulsion problem.

The question which arises is whether these explanations can be extended to all the oxides of the main group elements. Without being able to resolve the electronic basis of these relationships the general observation remains that the $\mathrm{O}$ atoms in the compounds reviewed in this paper are always located in the vicinity of the electron pairs of the parent structure of the element. A "freezing" of the elemental structure is therefore observed when the elements are oxidised and the oxide anions are located in the regions of high electron density in the element. Although we have sought to explain the structures in terms of thermodynamic preferences, it could be that there is also a kinetic effect which results in the retention of the parent structure as the reaction proceeds, because the activation energies for such processes leading to these symmetric structures are lower than those for alternative reactions which lead to other structural rearrangements. Therefore, the freezing of the structure may have its origins in the mechanistic pathway leading to their formation.

In support of this generalisation, we refer to the theoretical calculations carried out on suboxides of Zintl phases [35]. The compound $\mathrm{Ca}_{4} \mathrm{Sb}_{2} \mathrm{O}$ [36] was first described as a binary calcium antimonide $\mathrm{Ca}_{4} \mathrm{Sb}_{2}$ [37]. The structure contains isolated $\mathrm{Sb}^{3-}$ anions and the compound can only have the expected valency relationships if an additional $\mathrm{X}^{2-}$ anion is present. The additional anion was identified as $\mathrm{O}^{2-}$ and was located at the centre of a $\mathrm{Ca}_{6}$ octahedron. In fact, the calculation of the ELF for $\mathrm{Ca}_{4} \mathrm{Sb}_{2}$ (without the $\mathrm{O}$ atom) produced only one additional localisation region at the centre of the $\mathrm{Ca}_{6}$ octahedron, just the position occupied by the additional $\mathrm{O}$ atom.

\section{5}

\section{Silicates}

As it has been reported for the aluminates [8], the application of the ZintlKlemm concept to silicates turns out to be reasonable for the following reasons: on one hand because the main group elements maintain their structures when they form their corresponding oxides. On the other hand, because silicon is a Zintl element which, in the presence of very electropositive cations, behaves as a Zintl polyanion which can adopt the structure of other main 
group elements whose networks, as it occurs with the binary oxides, can be maintained as well in the silicate anions.

Next, the structures of silicates will be analysed in the light of these concepts. The selected compounds are collected in Tables 3 to 7. Examples of silicates are selected such that the application of the Zintl-Klemm concept to the large variety of silicate structures is elucidated and can be comprehended. Following the rules given in Sect. 2, the concise formulas can be developed into more detailed structural ones by considering the chain periodicity $P^{\mathrm{C}}$ and distinguishing the $\mathrm{T}$ atoms according to the values of $k, l, m$ and $n$ of their pseudo-atoms. For example, the formula of the unbranched zweier double chain silicate tremolite $\mathrm{Ca}_{2} \mathrm{Mg}_{5}\left[\mathrm{Si}_{4} \mathrm{O}_{11}\right]_{2}(\mathrm{OH})_{2}$ can be extended to $\mathrm{Ca}_{2}^{[8]} \mathrm{Mg}_{5}^{[6]}$ $\left\{\boldsymbol{u} \boldsymbol{B}, 2,2_{\infty}^{1}\right\}\left[\mathrm{Si}_{2}^{[1 ; 3]} \mathrm{Si}_{2}^{[1 ; 2\rfloor} \mathrm{O}_{11}\right]_{2}(\mathrm{OH})_{2}$.

References to examples listed in Tables 2-7 are given with small letters $a, b, \ldots$ if heterochemical silicates with the same general formula but different cations $\mathbf{A}, \mathbf{A}^{\prime}$, etc. are listed. Underlined element symbols indicate that a mineral name is given. For several mineral groups with a large number of members, no reference is given. Phases for which no mineral name is given in Tables 3-7 have been synthesised but not find in nature. In the text and in the tables, reference is made to the most recent and most accurate crystal structure refinements.

\section{1}

\section{Monosilicates}

Monosilicates are characterised by the existence of isolated $\left[\mathrm{SiO}_{4}\right]^{4-}$ anions. To this family of compounds belong very common minerals such as olivines $\mathbf{A}_{2}\left[\mathrm{SiO}_{4}\right]\left(\mathbf{A}^{1}=\mathrm{Mg}, \mathrm{Mn}, \mathrm{Fe}, \mathrm{Co}, \mathrm{Ni}\right)$, spinels, garnets $\mathbf{A}_{3} \mathbf{A}_{2}^{\prime}\left[\mathrm{SiO}_{4}\right]_{3}$ (with $\mathbf{A}=\mathrm{Mg}, \mathrm{Ca}, \mathrm{Mn}, \mathrm{Y}, \ldots, \mathbf{A}^{\prime}=\mathrm{Al}, \mathrm{Fe}, \mathrm{Cr}, \mathrm{V}, \ldots$ ), apatite-like silicates such as $\mathrm{Ca}_{3} \mathrm{Y}_{2}\left[\mathrm{SiO}_{4}\right]_{3}$ and $\mathrm{Y}_{5}\left[\mathrm{SiO}_{4}\right]_{3} \mathrm{~N}$, zircon $\mathrm{Zr}\left[\mathrm{SiO}_{4}\right]$, etc. In addition to these compounds, more than one hundred quaternary phases have been described, among them, compounds in which non-silicate anions coexist with the monosilicate anions.

In terms of the Zintl-Klemm concept, $\mathrm{a}\left[\mathrm{SiO}_{4}\right]^{4-}$ anion can be derived from a $\mathrm{Si}^{4-}$ anion, if electropositive atoms are able to transfer four electrons to the $\mathrm{Si}$ atom. The $\mathrm{Si}^{4-}$ anion has a noble gas configuration, $(\Psi-\mathrm{Ar})$, with four pairs of electrons in its valence shell. Now, if each of the electron pairs of a $\mathrm{Si}$ atom is approached by an $\mathrm{O}$ atom, the monosilicate anion is formed. Thus, in $\mathrm{Mg}_{2}\left[\mathrm{SiO}_{4}\right]$, the two $\mathrm{Mg}$ atoms per formula unit would transfer four electrons to the $\mathrm{Si}$ atom, converting it into $\mathrm{Si}^{4-}$, with a noble gas configuration.

\section{2}

\section{Oligosilicates}

A selection of oligosilicates $\mathbf{A}_{a} \mathbf{A}_{a^{\prime}}^{\prime} \ldots\{\boldsymbol{t}\}\left[\mathrm{Si}_{n} \mathrm{O}_{3 n+1}\right] \mathrm{Y}_{y} \mathrm{Z}_{z}$ is given in Table 3. 
Table 3

\begin{tabular}{|c|c|c|}
\hline Mineral name & $\begin{array}{c}\text { Oligosilicates } \\
\text { Disilicates } \\
\left\{\begin{array}{l}0 \\
\infty\end{array}\right\} \text { Pseudo- } \mathrm{Cl}_{2} \\
\text { Formula }\end{array}$ & Ref. \\
\hline \multirow[t]{5}{*}{ Suolunite } & $\mathrm{H}_{2} \mathrm{Ca}_{2}\left[\mathrm{Si}_{2} \mathrm{O}_{7}\right]\left(\mathrm{H}_{2} \mathrm{O}\right)$ & [193] \\
\hline & $\mathrm{Li}_{2} \mathrm{Cu}_{5}\left[\mathrm{Si}_{2} \mathrm{O}_{7}\right]_{2}$ & {$[194]$} \\
\hline & $\mathrm{Na}_{2} \mathrm{Si}^{[6]}\left[\mathrm{Si}_{2} \mathrm{O}_{7}\right]$ & {$[195]$} \\
\hline & $\mathrm{K}_{6}\left[\mathrm{Si}_{2} \mathrm{O}_{7}\right]$ & {$[196]$} \\
\hline & $\mathrm{Rb}_{2} \mathrm{Be}_{2}\left[\mathrm{Si}_{2} \mathrm{O}_{7}\right]$ & [197] \\
\hline Edgarbaileyite & $\mathbf{A}_{6}\left[\mathrm{Si}_{2} \mathrm{O}_{7}\right]$ with $\mathbf{A}=\mathrm{Ag}, \mathrm{Hg}(\mathrm{I}), \mathrm{Tl}(\mathrm{I})$ & {$[198 \mathrm{a}-\mathrm{c}]$} \\
\hline Bertrandite & $\mathrm{Be}_{4}\left[\mathrm{Si}_{2} \mathrm{O}_{7}\right](\mathrm{OH})_{2}$ & [199] \\
\hline Barylite, clinobarylite & $\mathrm{Be}_{2} \mathrm{Ba}\left[\mathrm{Si}_{2} \mathrm{O}_{7}\right]$ & [200a-b] \\
\hline Rankinite & $\mathrm{Ca}_{3}\left[\mathrm{Si}_{2} \mathrm{O}_{7}\right]$ & {$[201]$} \\
\hline Cuspidine & $\mathrm{Ca}_{4}\left[\mathrm{Si}_{2} \mathrm{O}_{7}\right] \mathrm{F}_{2}$ & {$[202]$} \\
\hline \multirow[t]{2}{*}{ Wadsleyite } & $\mathrm{Mg}_{4}\left[\mathrm{Si}_{2} \mathrm{O}_{7}\right] \mathrm{O}$ & [203] \\
\hline & $\mathrm{Ca}_{2} \mathrm{Y}_{2}\left[\mathrm{Si}_{2} \mathrm{O}_{7}\right] \mathrm{O}_{2}$ & [204] \\
\hline Gittinsite & $\mathrm{CaZr}\left[\mathrm{Si}_{2} \mathrm{O}_{7}\right]$ & {$[205]$} \\
\hline Baghdadite & $\mathrm{Ca}_{3} \mathrm{Zr}\left[\mathrm{Si}_{2} \mathrm{O}_{7}\right] \mathrm{O}_{2}$ & {$[206]$} \\
\hline Andremeyerite & $\mathrm{BaFe}_{2}\left[\mathrm{Si}_{2} \mathrm{O}_{7}\right]$ & {$[207]$} \\
\hline \multirow[t]{2}{*}{ Fresnoite } & $\mathrm{Ba}_{2} \mathrm{Ti}\left[\mathrm{Si}_{2} \mathrm{O}_{7}\right] \mathrm{O}$ & [208] \\
\hline & $\mathrm{Ba}_{2} \mathrm{Mn}(\mathrm{III})_{2}\left[\mathrm{Si}_{2} \mathrm{O}_{7}\right] \mathrm{O}_{2}$ & [209] \\
\hline Belkovite & $\mathrm{Ba}_{3} \mathrm{Nb}_{6}\left[\mathrm{Si}_{2} \mathrm{O}_{7}\right]_{2} \mathrm{O}_{12}$ & [210] \\
\hline \multirow{4}{*}{ Hemimorphite } & $\mathrm{Zn}_{4}\left[\mathrm{Si}_{2} \mathrm{O}_{7}\right](\mathrm{OH})_{2}\left(\mathrm{H}_{2} \mathrm{O}\right)$ & {$[211]$} \\
\hline & $\mathrm{Al}_{3}\left[\mathrm{Si}_{2} \mathrm{O}_{7}\right](\mathrm{OH})_{3}$ & {$[212]$} \\
\hline & $\mathrm{Y}_{4}\left[\mathrm{Si}_{2} \mathrm{O}_{5} \mathrm{~N}_{2}\right] \mathrm{O}_{2}$ & {$[213]$} \\
\hline & $\mathrm{In}_{2}\left[\mathrm{Si}_{2} \mathrm{O}_{7}\right]$ & {$[214]$} \\
\hline \multirow[t]{6}{*}{$\begin{array}{l}\text { Thortveitite, yttrialite, } \\
\text { keiviite }\end{array}$} & $\begin{array}{l}\mathbf{A}_{2}\left[\mathrm{Si}_{2} \mathrm{O}_{7}\right] \text { with } \mathrm{A}=\underline{\mathrm{Sc}}, \underline{\mathrm{Y}}, \mathrm{La}, \mathrm{Ce}, \mathrm{Pr}, \mathrm{Nd} \\
\mathrm{Sm}, \mathrm{Eu}, \mathrm{Gd}, \mathrm{Ho}, \mathrm{Er}, \underline{\mathrm{Yb}}\end{array}$ & {$[215 \mathrm{a}-\mathrm{q}]$} \\
\hline & $\mathrm{A}_{3}\left[\mathrm{Si}_{2} \mathrm{O}_{7}\right] \mathrm{Cl}_{3}$ with $\overline{\mathrm{A}}=\mathrm{La}, \mathrm{Pr}$ & [216a-b] \\
\hline & $\mathrm{Si}^{\left[{ }^{[6]}\right.}\left[\mathrm{P}_{2} \mathrm{O}_{7}\right]$ & {$[217 \mathrm{a}-\mathrm{d}]$} \\
\hline & $\begin{array}{l}\text { Unbranched Trisilicates } \\
\left\{\left\{\begin{array}{l}0 \\
\infty\end{array}\right\} \text { Pseudo- } \mathrm{SCl}_{2}\right.\end{array}$ & \\
\hline & $\mathrm{H}_{2} \mathrm{~K}_{3} \mathrm{~A}\left[\mathrm{Si}_{3} \mathrm{O}_{10}\right]$ with $\mathrm{A}=\mathrm{Y}, \mathrm{Tb}, \mathrm{Eu}(\mathrm{III})$ & [218] \\
\hline & $\mathrm{Er}, \mathrm{Tb}, \mathrm{Gd}$ & \\
\hline \multirow[t]{3}{*}{ Rosenhahnite } & $\mathrm{H}_{2} \mathrm{Ca}_{3}\left[\mathrm{Si}_{3} \mathrm{O}_{10}\right]$ & [219] \\
\hline & $\mathrm{A}_{3}\left[\mathrm{Si}_{3} \mathrm{O}_{10}\right] \mathrm{F}$ with $\mathrm{A}=\mathrm{Y}, \mathrm{Dy}, \mathrm{Ho}, \mathrm{Er}$ & {$[220 \mathrm{a}-\mathrm{b}]$} \\
\hline & $\begin{array}{l}\text { Unbranched Tetrasilicates } \\
\left\{\begin{array}{l}0 \\
\infty\end{array}\right\} \text { Pseudo- } \mathrm{S}_{2} \mathrm{Cl}_{2}\end{array}$ & \\
\hline Ruizite & $\mathrm{H}_{2} \mathrm{Ca}_{2} \mathrm{Mn}(\mathrm{III})_{2}\left[\mathrm{Si}_{4} \mathrm{O}_{13}\right](\mathrm{OH})_{2}\left(\mathrm{H}_{2} \mathrm{O}\right)_{2}$ & [221a-b] \\
\hline \multirow[t]{5}{*}{ Akatoreite } & $\mathrm{H}_{2} \mathrm{Mn}(\mathrm{II})_{9} \mathrm{Al}_{2}\left[\mathrm{Si}_{4} \mathrm{O}_{13}\right]_{2}(\mathrm{OH})_{6}$ & {$[222]$} \\
\hline & $\mathrm{Na}_{4} \mathrm{Sc}_{2}\left[\mathrm{Si}_{4} \mathrm{O}_{13}\right]$ & {$[223]$} \\
\hline & $\mathrm{Rb}_{2} \mathrm{Si}^{[6]}\left[\mathrm{P}_{4} \mathrm{O}_{13}\right]$ & [224] \\
\hline & $\mathrm{Ag}_{10}\left[\mathrm{Si}_{4} \mathrm{O}_{13}\right]$ & {$[225]$} \\
\hline & $\mathrm{Ba}_{2} \mathrm{Nd}_{2}\left[\mathrm{Si}_{4} \mathrm{O}_{13}\right]$ & {$[226]$} \\
\hline
\end{tabular}

continued on next page 
Table 3 (continued)

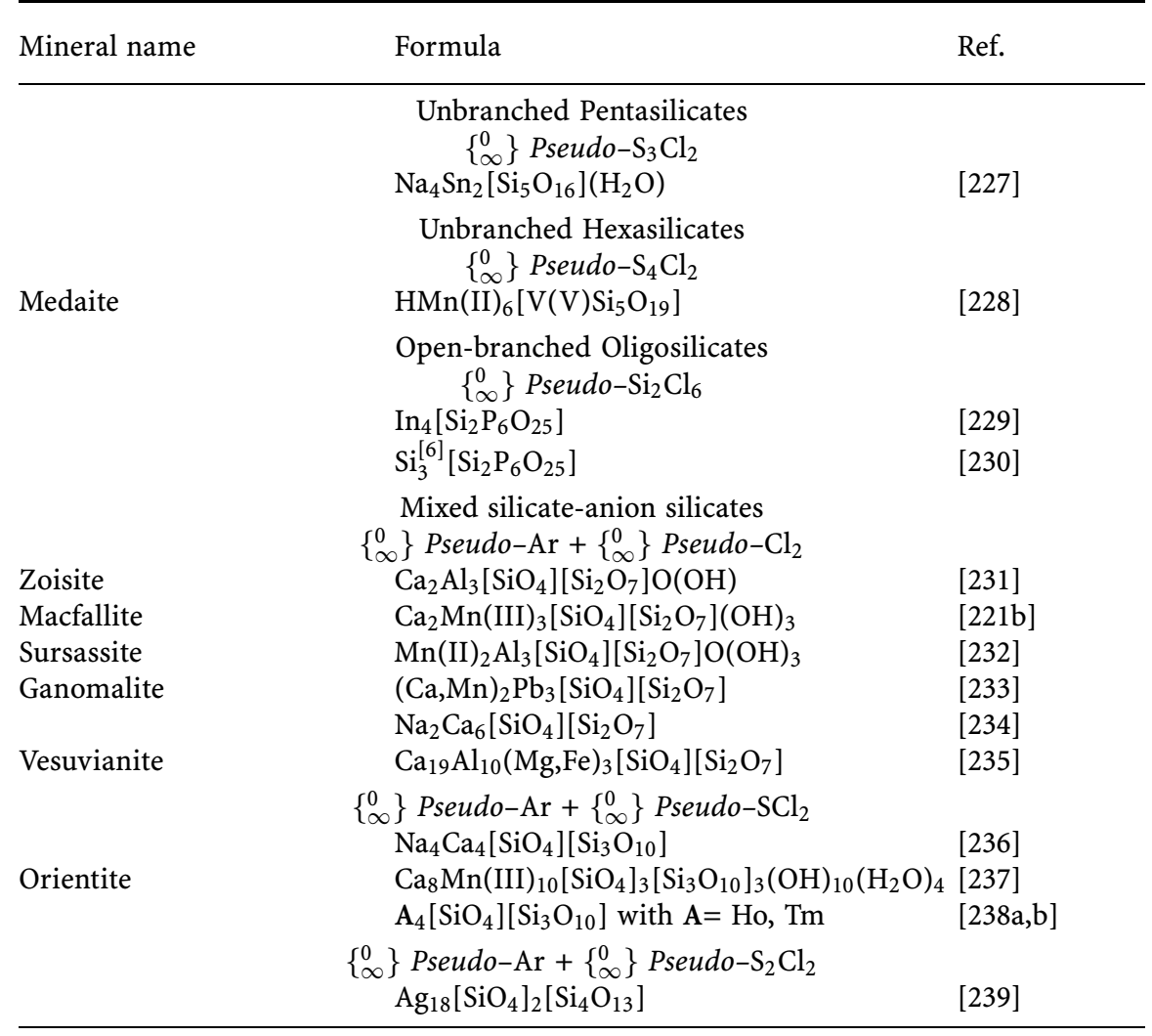

\subsection{1}

\section{Disilicates}

This group of silicates is characterised by isolated $\left[\mathrm{Si}_{2} \mathrm{O}_{7}\right]^{6-}$ anions. Each anion consists of two $\left[\mathrm{SiO}_{4}\right]$ tetrahedra joined by a common corner as seen in Fig. 3. Such anions are present in the ternary silicates $\mathbf{A}_{6}\left[\mathrm{Si}_{2} \mathrm{O}_{7}\right](\mathbf{A}=\mathrm{Li}$, $\mathrm{K}, \mathrm{Rb}, \mathrm{Cs}, \mathrm{Ag}, \mathrm{Tl})$, rankinite $\mathrm{Ca}_{3}\left[\mathrm{Si}_{2} \mathrm{O}_{7}\right]$, in the mineral wadsleyite which is a high pressure phase of composition $\mathrm{Mg}_{2} \mathrm{SiO}_{4}$ and in the HP phase of $\mathrm{Na}_{2} \mathrm{Si}_{3} \mathrm{O}_{7}$, as well as in $\mathrm{In}_{2}\left[\mathrm{Si}_{2} \mathrm{O}_{7}\right]$ and $\mathrm{A}(\mathrm{III})_{2}\left[\mathrm{Si}_{2} \mathrm{O}_{7}\right]$ with $\mathrm{A}(\mathrm{III})=\mathrm{Sc}, \mathrm{Y}, \mathrm{La}$, $\mathrm{Ce}, \mathrm{Pr}, \mathrm{Nd}, \mathrm{Sm}, \mathrm{Eu}, \mathrm{Gd}, \mathrm{Ho}, \mathrm{Er}, \mathrm{Yb}$. More than 60 quaternary disilicates have also been reported. The $\mathrm{Si}$ subarray is formed by $(\mathrm{Si}-\mathrm{Si})^{6-}$ dimers which are isoelectronic with a halogen $\mathbf{X}-\mathbf{X}$ molecule. This indicates that the ZintlKlemm concept can be applied to them. Thus, if for example the six alkali metal atoms per formula unit would donate six electrons to the two silicon atoms, they would be converted into two $\Psi$-Cl, adopting the form of a $\Psi-\mathrm{Cl}_{2}$ molecule. In the latter, the two $\Psi$-Cl atoms are bonded by a single $\sigma$-bond 


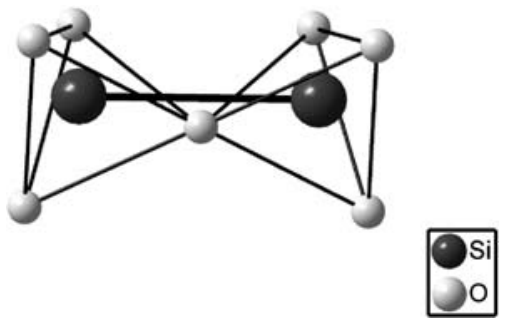

Fig. 3 The structure of the disilicate anion $\left[\mathrm{Si}_{2} \mathrm{O}_{7}\right]^{6-}$ in $\mathrm{K}_{6}\left[\mathrm{Si}_{2} \mathrm{O}_{7}\right]$, consisting of two tetrahedra connected by a common corner. It can be considered as a $\Psi-\mathrm{Cl}_{2}$ molecule. The $\mathrm{O}$ atoms are docked close to the $\mathrm{Cl}-\mathrm{Cl}$ bond and to the three lone pairs of each $\Psi$-Cl atom. The structure resembles that of the $\mathrm{Cl}_{2} \mathrm{O}_{7}$ molecule

and the two octets are completed by three lone pairs on each Si atom, situated tetrahedrally with respect to the bond line. Now, if $\mathrm{O}$ atoms are located close to these lone pairs and also close to the midpoint of the bond line, we obtain the structure of the disilicate anion (see Fig. 3). It is worth mentioning that this anion has the same conformation as the molecule of $\mathrm{Cl}_{2} \mathrm{O}_{7}$ [38].

An interesting example is that provided by the $\mathrm{HP}$ phase $\mathrm{Na}_{2} \mathrm{Si}_{3} \mathrm{O}_{7}$ [39]. This silicate can be written as $\mathrm{Na}_{2} \mathrm{Si}^{i}{ }^{6]}\{\boldsymbol{t}\}\left[\mathrm{Si}_{2}^{[4]} \mathrm{O}_{7}\right]$. Its unit cell contains four formula units. An important characteristic of this compound is that it presents two kinds of coordination polyhedra for silicon. Four Si atoms per unit cell are hexa-coordinated and the eight remaining silicon atoms have tetrahedral coordination, forming four disilicate anions $\left[\mathrm{Si}_{2} \mathrm{O}_{7}\right]^{6-}$. To account for this geometry, one has to assume that each tetrahedrally coordinated $\mathrm{Si}$ atom has received $3 \mathrm{e}^{-}$(a total of $24 \mathrm{e}^{-}$) transforming it into $\Psi$-Cl and every two of them mimicking the structure of a $\mathrm{Cl}_{2}$ molecule. These $24 \mathrm{e}^{-}$are provided by the eight $\mathrm{Na}$ atoms $\left(8 \mathrm{e}^{-}\right)$and by the four hexa-coordinated $\mathrm{Si}$ atoms $\left(16 \mathrm{e}^{-}\right)$. This indicates that the $\mathrm{Si}$ atoms have an amphoteric character which seems to be induced by the application of pressure. It should be mentioned that this phenomenon was also observed in the structures of aluminates [8] in which the basicity can be identified with the octahedral coordination (as in silicon) whereas the acceptor character leads to the formation of Zintl polyanions and hence to the tetrahedral coordination.

\subsection{2}

\section{Other Oligosilicates}

In this section, we will discuss some compounds which contain small, discrete, unbranched or branched, groups of $n\left[\mathrm{TO}_{4}\right]$ tetrahedra, as listed in Table 3.

$\mathrm{Na}_{4} \mathrm{Cd}_{2}\left[\mathrm{Si}_{3} \mathrm{O}_{10}\right]$ [40] contains groups of three tetrahedra forming discrete anions $\left[\mathrm{Si}_{3} \mathrm{O}_{10}\right]^{8-}$ which are represented in Fig. 4 . The $\mathrm{T}$ atom skeleton is 


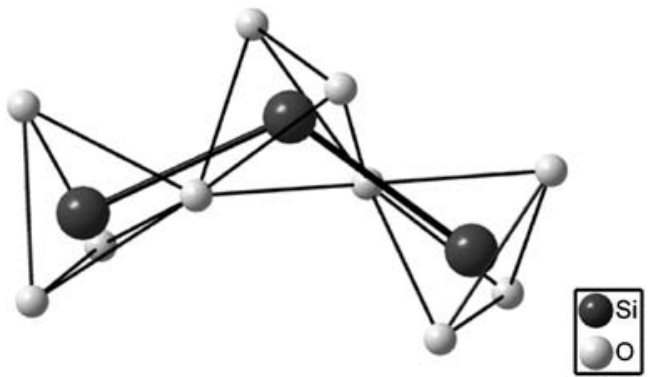

Fig. 4 The structure of the oligosilicate anion $\left[\mathrm{Si}_{3} \mathrm{O}_{10}\right]^{8-}$ in $\mathrm{Na}_{4} \mathrm{Cd}_{2}\left[\mathrm{Si}_{3} \mathrm{O}_{10}\right]$ consists of three tetrahedra connected by common corners. Its $\mathrm{Si}$ subarray adopts the same structure as the $\mathrm{SCl}_{2}$ molecule

not linear, the $\mathrm{Si}-\mathrm{Si}-\mathrm{Si}$ angle being $114.33^{\circ}$. This structure can be understood in the light of the Zintl-Klemm concept. The $\mathrm{Na}$ and $\mathrm{Cd}$ atoms can donate $8 \mathrm{e}^{-}$per formula unit to the $\mathrm{Si}$ atoms. The central one is converted into $\Psi$-S and the two terminal ones are converted into $\psi$-Cl. The final pseudostoichiometry would be $\Psi-\mathrm{SCl}_{2}$. The real $\mathrm{SCl}_{2}$ molecule is similar in geometry although with a lower $\mathrm{Cl}-\mathrm{S}-\mathrm{Cl}$ angle of $102.48^{\circ}$.

In $\mathrm{Ag}_{10}\left[\mathrm{Si}_{4} \mathrm{O}_{13}\right]$ [41], every four $\left[\mathrm{TO}_{4}\right]$ tetrahedra are linearly connected as represented in Fig. 5. This oligosilicate anion can also be explained by the Zintl-Klemm concept. The $10 \mathrm{e}^{-}$per formula unit provided by the Ag atoms convert the two central $\mathrm{Si}$ atoms into $\Psi$-S and the two terminal ones into $\Psi$-Cl, giving rise to a pseudo-anion of stoichiometry $\Psi-\mathrm{S}_{2} \mathrm{Cl}_{2}$. The geometry is similar to that of the Zintl polyanion found in $\mathrm{Ba}_{3} \mathrm{P}_{4}$ (also with $\Psi$ $\mathrm{S}_{2} \mathrm{Cl}_{2}$ stoichiometry) [42]. A similar $\mathrm{T}$ atom subarray exists in the aluminate $\mathrm{Na}_{14}\left[\mathrm{Al}_{4} \mathrm{O}_{13}\right][8]$.

As an example of a branched oligosilicate the structure of $\operatorname{In}_{4}\left[\mathrm{Si}_{2} \mathrm{P}_{6}\right.$ $\mathrm{O}_{25}$ ] [43] will be discussed. This silicophosphate anion has an interesting

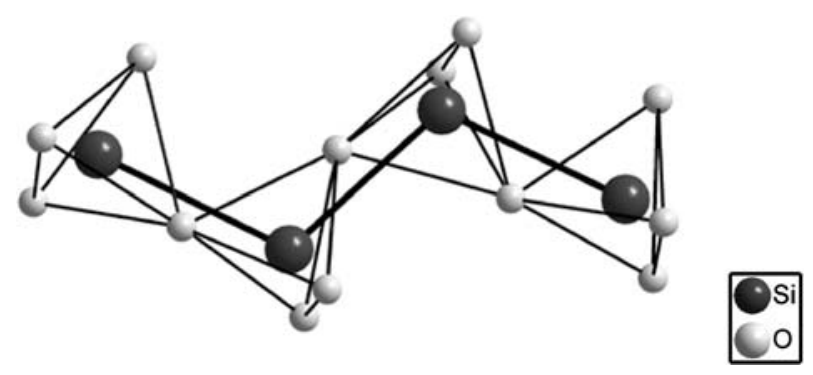

Fig. 5 The oligosilicate anion $\left[\mathrm{Si}_{4} \mathrm{O}_{13}\right]^{10-}$ in $\mathrm{Ag}_{10}\left[\mathrm{Si}_{4} \mathrm{O}_{13}\right]$ is formed by four $\left[\mathrm{SiO}_{4}\right]$ tetrahedra which are connected by common corners. The Si subarray contains groups of four $\mathrm{Si}$ atoms resembling the Zintl polyanion $\left[\mathrm{P}_{4}\right]^{6-}$ in the Zintl phase $\mathrm{Ba}_{3} \mathrm{P}_{4}$ 


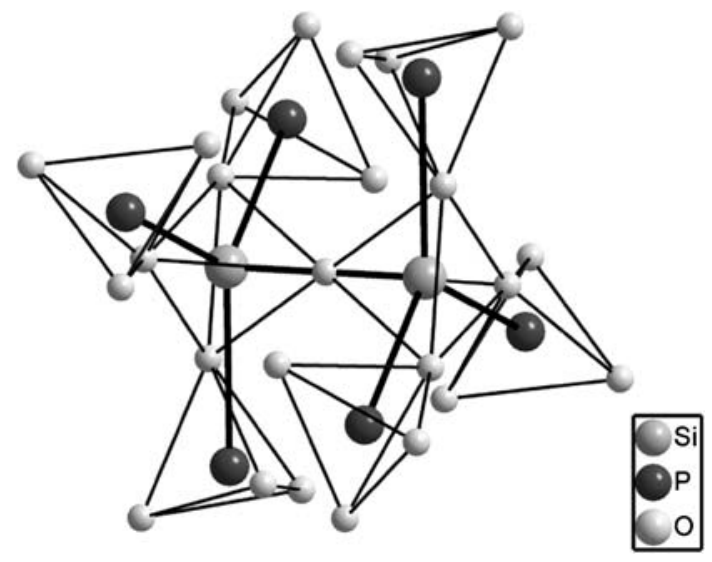

Fig. 6 The structure of the anion $\left[\mathrm{Si}_{2} \mathrm{P}_{6} \mathrm{O}_{25}\right]^{12-}$ existing in $\operatorname{In}_{4}\left[\mathrm{Si}_{2} \mathrm{P}_{6} \mathrm{O}_{25}\right]$. The two central $\mathrm{Si}$ atoms remain as silicon atoms adopting a four-fold connectivity. The $\mathrm{P}$ atoms are converted into mono-connected $\Psi$-halogen. The resulting stoichiometry is $\Psi$ - $\mathrm{Si}_{2} \mathrm{Cl}_{6}$. The structure resembles that of the Zintl polyanion $\left[\mathrm{Sn}_{2} \mathrm{P}_{6}\right]^{12-}$ in the Zintl phase $\mathrm{Ba}_{6} \mathrm{Sn}_{2} \mathrm{P}_{6}$ and also that of the $\mathrm{Si}_{2} \mathrm{I}_{6}$ molecule

structure which is represented in Fig. 6. It is formed by two Si-centred tetrahedra per formula unit which share one corner. Each of these tetrahedra are further linked, by common corners, to three P-centred tetrahedra. Looking at the $\mathrm{Si}-\mathrm{P}$ subarray, it can be seen that its structure is similar to that of $\mathrm{a}_{2} \mathrm{H}_{6}$ molecule. If we apply the Zintl-Klemm concept we see that the 12 electrons per formula unit provided by the In atoms can serve to convert the $6 \mathrm{P}$ atoms into $\Psi$ - $\mathrm{Cl}$ in such a way that the final stoichiometry is $\Psi-\mathrm{Si}_{2} \mathrm{Cl}_{6}$ and this is just the conformation of the similar $\mathrm{Si}_{2} \mathrm{I}_{6}$ molecule. The T-atom subarray is also similar to the $\left[\mathrm{Sn}_{2} \mathrm{P}_{6}\right]^{12-}$ polyanion in the Zintl phase $\mathrm{Ba}_{6} \mathrm{Sn}_{2} \mathrm{P}_{6}$ [44]. The same T-atom subarray also exists in $\mathrm{Si}_{3}^{[6]}\left[\mathrm{Si}_{2}^{[4]} \mathrm{P}_{6} \mathrm{O}_{25}\right]$ [45], a compound in which, again, silicon has an amphoteric character by which the donor $\mathrm{Si}$ atoms are octahedrally coordinated whereas the acceptor Si atoms are tetrahedrally coordinated forming part of the tetrahedral anions.

\section{3}

\section{Ring Silicates}

A list of ring silicates is given in Table 4 .

\subsection{1}

\section{Single-Ring Silicates}

The compounds which will be discussed next have in common the existence of isolated rings of condensated $\left[\mathrm{SiO}_{4}\right]$ groups which share two corners each 


\section{Table 4}

\begin{tabular}{|c|c|c|c|c|}
\hline Mineral name & $\begin{array}{c}\text { Ring silicates } \\
\text { Single-ring silicates } \\
\{1 r\} \text { Pseudo- } S_{m}\end{array}$ & $P^{\mathrm{R}}$ & $m$ & Ref. \\
\hline & $\mathbf{A}_{6}\left[\mathrm{Si}_{3} \mathrm{O}_{9}\right]$ with $\mathbf{A}=\mathrm{K}, \mathrm{Rb}, \mathrm{Cs}$ & 3 & 3 & {$[240]$} \\
\hline & $\mathrm{A}_{2} \mathrm{Be}_{2}\left[\mathrm{Si}_{3} \mathrm{O}_{9}\right]$ with $\mathrm{A}=\mathrm{Na}, \mathrm{K}$ & 3 & 3 & {$[241 \mathrm{a}-\mathrm{b}]$} \\
\hline Pseudowollastonite & $\mathbf{A}_{3}\left[\mathrm{Si}_{3} \mathrm{O}_{9}\right]$ with $\mathbf{A}=\underline{\mathrm{Ca}}, \mathrm{Sr}$ & 3 & 3 & {$[242 \mathrm{a}-\mathrm{b}]$} \\
\hline \multirow[t]{2}{*}{ Ca-catapleite } & $\mathrm{CaZr}\left[\mathrm{Si}_{3} \mathrm{O}_{9}\right]\left(\mathrm{H}_{2} \mathrm{O}\right)_{2}$ & 3 & 3 & {$[243]$} \\
\hline & $\mathrm{Ca}_{3} \mathrm{Y}_{2}\left[\mathrm{Si}_{3} \mathrm{O}_{9}\right]_{2}$ & 3 & 3 & {$[244]$} \\
\hline \multirow{4}{*}{$\begin{array}{l}\text { Benitoite, bazirite } \\
\text { pabstite }\end{array}$} & $\mathrm{BaA}\left[\mathrm{Si}_{3} \mathrm{O}_{9}\right]$ with $\mathrm{A}=\mathrm{Si}, \underline{\mathrm{Ti}, \mathrm{Zr}, \mathrm{Sn}}$ & 3 & 3 & {$[245]$} \\
\hline & $\mathrm{La}_{3}\left[\mathrm{Si}_{3} \mathrm{O}_{9}\right] \mathrm{F}_{3}$ & 3 & 3 & {$[246]$} \\
\hline & $\mathrm{H}_{4} \mathrm{~K}_{4}\left[\mathrm{Si}_{4} \mathrm{O}_{12}\right]$ & 4 & 4 & [247] \\
\hline & $\mathbf{A}_{8}\left[\mathrm{Si}_{4} \mathrm{O}_{12}\right] \mathrm{Cl}_{8}$ with $\mathbf{A}=\mathrm{Ca}, \mathrm{Eu}(\mathrm{II})$ & 4 & 4 & {$[248 \mathrm{a}-\mathrm{b}]$} \\
\hline \multirow[t]{8}{*}{ Papagoite } & $\mathrm{Ca}_{2} \mathrm{Cu}_{2} \mathrm{Al}_{2}\left[\mathrm{Si}_{4} \mathrm{O}_{12}\right](\mathrm{OH})_{6}$ & 4 & 4 & [249] \\
\hline & $\mathrm{Ca}_{2} \mathrm{Zr}\left[\mathrm{Si}_{4} \mathrm{O}_{12}\right]$ & 4 & 4 & {$[250]$} \\
\hline & $\mathrm{Sr}_{4}\left[\mathrm{Si}_{4} \mathrm{O}_{12}\right]$ & 4 & 4 & {$[251]$} \\
\hline & $\mathrm{Ba}_{2} \mathrm{Cu}_{2}\left[\mathrm{Si}_{4} \mathrm{O}_{12}\right]$ & 4 & 4 & {$[252]$} \\
\hline & $\mathrm{Ba}_{2} \mathrm{~V}_{2}\left[\mathrm{Si}_{4} \mathrm{O}_{12}\right] \mathrm{O}_{2}$ & 4 & 4 & {$[253]$} \\
\hline & $\mathrm{Na}_{4} \mathrm{Ca}_{4}\left[\mathrm{Si}_{6} \mathrm{O}_{18}\right]$ & 6 & 6 & {$[254]$} \\
\hline & $\mathrm{Na}_{6} \mathrm{Sr}_{3}\left[\mathrm{Si}_{6} \mathrm{O}_{18}\right]$ & 6 & 6 & {$[255]$} \\
\hline & $\mathrm{Na}_{8} \mathrm{Si}^{[6]}\left[\mathrm{Si}_{6} \mathrm{O}_{18}\right]$ & 6 & 6 & {$[256]$} \\
\hline Petarasite & $\mathrm{Na}_{5} \mathrm{Zr}_{2}\left[\mathrm{Si}_{6} \mathrm{O}_{18}\right]_{2} \mathrm{Cl}\left(\mathrm{H}_{2} \mathrm{O}\right)$ & 6 & 6 & {$[257]$} \\
\hline Beryl & $\mathrm{Be}_{3} \mathrm{Al}_{2}\left[\mathrm{Si}_{6} \mathrm{O}_{18}\right]$ & 6 & 6 & {$[258]$} \\
\hline Scawtite & $\mathrm{Ca}_{7}\left[\mathrm{Si}_{6} \mathrm{O}_{18}\right]\left(\mathrm{CO}_{3}\right)\left(\mathrm{H}_{2} \mathrm{O}\right)_{2}$ & 6 & 6 & {$[259]$} \\
\hline Dioptase & $\mathrm{Cu}_{6}\left[\mathrm{Si}_{6} \mathrm{O}_{18}\right]\left(\mathrm{H}_{2} \mathrm{O}\right)_{6}$ & 6 & 6 & {$[260]$} \\
\hline \multirow[t]{4}{*}{ Muirite } & $\mathrm{Ca}_{2} \mathrm{Ba}_{10} \mathrm{Ti}_{2}\left[\mathrm{Si}_{8} \mathrm{O}_{24}\right](\mathrm{OH}, \mathrm{Cl})_{16}$ & 8 & 8 & {$[261]$} \\
\hline & $\mathrm{Na}_{6} \mathrm{Si}_{3}^{[6]}\left[\mathrm{Si}_{9} \mathrm{O}_{27}\right]$ & 9 & 9 & {$[262]$} \\
\hline & $\begin{array}{l}\mathbf{A}(\mathrm{I})_{15} \mathrm{~A}(\mathrm{III})_{3}\left[\mathrm{Si}_{12} \mathrm{O}_{36}\right] \text { with } \mathrm{A}(\mathrm{I})=\mathrm{Na}, \mathrm{Ag} \\
\mathbf{A}(\mathrm{III})=\mathrm{Sc}, \mathrm{Y}, \mathrm{REE}\end{array}$ & 12 & 12 & {$[263]$} \\
\hline & $\begin{array}{l}\mathbf{A}(\mathrm{I})_{16} \mathrm{~A}(\mathrm{II})_{4}\left[\mathrm{Si}_{12} \mathrm{O}_{36}\right] \text { with } \mathbf{A}(\mathrm{I})=\mathrm{Na}, \mathrm{K} \\
\mathbf{A}(\mathrm{II})=\mathrm{Ca}, \mathrm{Sr}\end{array}$ & 12 & 12 & {$[264]$} \\
\hline \multirow[t]{3}{*}{ Megacyclite } & $\mathrm{H}_{18} \mathrm{Na}_{16} \mathrm{~K}_{2}\left[\mathrm{Si}_{18} \mathrm{O}_{54}\right]\left(\mathrm{H}_{2} \mathrm{O}\right)_{38}$ & 18 & 18 & {$[265]$} \\
\hline & $\begin{array}{l}\text { Double-ring silicates } \\
\{u B, 2 r\} \text { Pseudo- } \mathrm{P}_{m}\end{array}$ & & & \\
\hline & $\mathrm{Na}_{3} \mathrm{Y}\left[\mathrm{Si}_{6} \mathrm{O}_{15}\right]$ & 3 & 6 & [266] \\
\hline Moskvinite & $\mathrm{Na}_{2} \mathrm{~K}(\mathrm{Y}, \mathrm{REE})\left[\mathrm{Si}_{6} \mathrm{O}_{15}\right]$ & 3 & 6 & {$[267]$} \\
\hline $\begin{array}{l}\text { Turkestanite, } \\
\text { steacyite,arapovite }\end{array}$ & $\begin{array}{l}\mathrm{K}_{1-x}(\mathrm{Ca}, \mathrm{Na})_{2} \mathrm{~A}(\mathrm{IV})\left[\mathrm{Si}_{8} \mathrm{O}_{20}\right]\left(\mathrm{H}_{2} \mathrm{O}\right)_{n} \\
\text { with } \mathbf{A}=\mathrm{Th}, \mathrm{U}\end{array}$ & 4 & 8 & {$[268 \mathrm{a}-\mathrm{c}]$} \\
\hline Milarite & $\mathrm{KBe}_{2} \mathrm{Ca}_{2} \mathrm{Al}\left[\mathrm{Si}_{12} \mathrm{O}_{30}\right]\left(\mathrm{H}_{2} \mathrm{O}\right)_{1-x}$ & 6 & 12 & [269] \\
\hline Osumilite & $(\mathrm{Na}, \mathrm{K})(\mathrm{Fe}, \mathrm{Mg})_{2}(\mathrm{Al}, \mathrm{Fe})_{3}\left[(\mathrm{Al}, \mathrm{Si})_{12} \mathrm{O}_{30}\right]$ & 6 & 12 & {$[270]$} \\
\hline
\end{tabular}

with two adjacent tetrahedra. They are grouped according to the number of tetrahedra forming a ring (ring periodicity $P^{\mathrm{R}}=3,4,6,8,9,12,18$ ). 
Following the Zintl-Klemm concept, the electropositive cations provide two electrons to each $\mathrm{Si}$ atom converting them into $\Psi$-S. An example of this is the mineral pabstite $\mathrm{BaSn}\left[\mathrm{Si}_{3} \mathrm{O}_{9}\right][46]$ in which isolated cyclic $\left[\mathrm{Si}_{3} \mathrm{O}_{9}\right]^{6-}$ anions exist. This can be interpreted as if the $\mathrm{Ba}$ and $\mathrm{Sn}$ atoms would donate $6 \mathrm{e}^{-}$to the three Si atoms, converting them into pseudo-S ( $\Psi-S_{3}$ molecule). Thus, in these kinds of compounds, the Si atoms adopt the structures of several different molecules observed in elemental sulfur, that is, the triangular $S_{3}$ molecules observed in sulfur vapour [47], the square $S_{4}$ molecule, also observed in the gas phase [48], the chair-conformed $S_{6}$ rings and the puckered $S_{8}$ rings existing in crystalline sulfur $[49,50]$, and the $S_{12}$ molecules, also stable in the solid state [51]. Several such polyanions are represented in Fig. 7. If the $\mathrm{O}$ atoms are located close to the two lone pairs and also in the vicinity of the midpoints of the two hypothetical Si - Si bonds, the tetrahedral coordina-

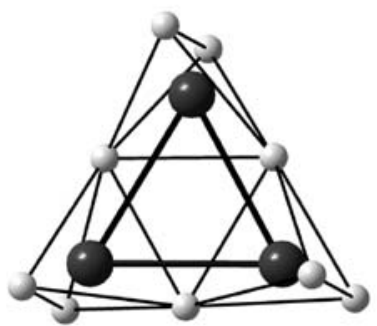

$O$ Si
0

a

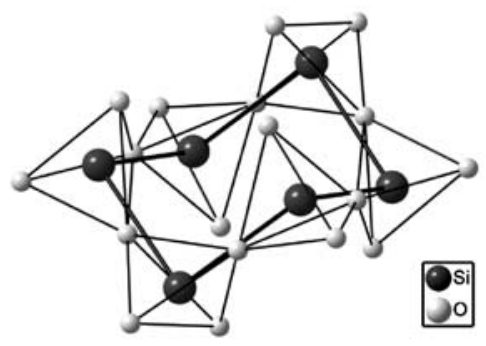

c

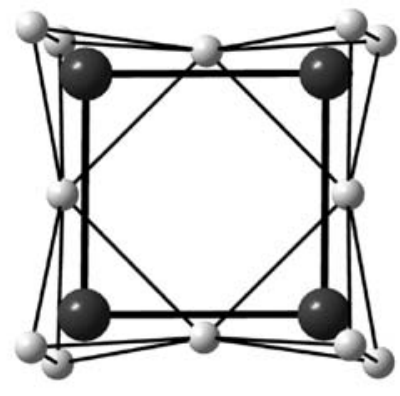

Si

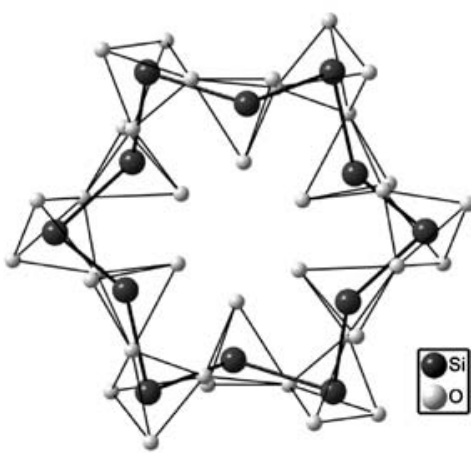

d

Fig. 7 The structures of the ring silicate anions $\left[\mathrm{Si}_{3} \mathrm{O}_{9}\right]^{6-}(\mathbf{a}),\left[\mathrm{Si}_{4} \mathrm{O}_{12}\right]^{8-}(\mathbf{b}),\left[\mathrm{Si}_{6} \mathrm{O}_{18}\right]^{12-}$ (c) and $\left[\mathrm{Si}_{12} \mathrm{O}_{36}\right]^{24-}$ (d), found in the compounds $\mathrm{K}_{6}\left[\mathrm{Si}_{3} \mathrm{O}_{9}\right], \mathrm{Sr}_{4}\left[\mathrm{Si}_{4} \mathrm{O}_{12}\right], \mathrm{Na}_{4} \mathrm{Ca}_{4}\left[\mathrm{Si}_{6} \mathrm{O}_{18}\right]$ and $\mathrm{Na}_{15} \mathrm{Sc}_{3}\left[\mathrm{Si}_{12} \mathrm{O}_{36}\right]$ respectively. In all of them, the $\mathrm{Si}$ atoms behave as pseudo-S adopting the structures of cyclic $S_{3}, S_{4}, S_{6}$ and $S_{12}$ molecules respectively 
tion of silicon is obtained. These hypothetical $\mathrm{Si}-\mathrm{Si}$ bonds are also drawn in Fig. 7.

A special case is the HP phase ( $2 \mathrm{GPa}$ ) of $\mathrm{K}_{2} \mathrm{Si}_{4} \mathrm{O}_{9}$ [52]. According to the crystal chemical formula $\mathrm{K}_{2} \mathrm{Si}^{[6]}\{\boldsymbol{u} \boldsymbol{B}, 3,1 \boldsymbol{r}\}\left[\mathrm{Si}_{3} \mathrm{O}_{9}\right]$, its structure contains two types of coordination polyhedra around silicon, i.e. octahedra and tetrahedra. The latter form three-membered rings. It can be interpreted under the assumption that the two $\mathrm{K}$ atoms and the hexa-coordinated $\mathrm{Si}$ atom, per formula unit, would donate their valence electrons to the three tetra-coordinated $\mathrm{Si}$ atoms. Thus, the HP polymorph of $\mathrm{K}_{2} \mathrm{Si}_{4} \mathrm{O}_{9}$ shows a skeleton in which the $\mathrm{T}$ atoms are converted into $\Psi$-S ions forming isolated $\Psi$-S $\mathrm{S}_{3}$ molecules.

A similar amphoteric behaviour of the $\mathrm{Si}$ atoms is found in the silicates $\mathrm{Na}_{8} \mathrm{Si}^{[6]}\{\boldsymbol{u} \boldsymbol{B}, 1 \boldsymbol{r}\}\left[\mathrm{Si}_{6}^{[4]} \mathrm{O}_{18}\right][53]$ and $\mathrm{Na}_{6} \mathrm{Si}_{3}^{[6]}\{\boldsymbol{u} \boldsymbol{B}, 1 \boldsymbol{r}\}\left[\mathrm{Si}_{9}^{[4]} \mathrm{O}_{27}\right][54]$.

\subsection{2}

\section{Double-Ring Silicates}

This group of compounds contains pairs of rings connected with each other. One of these compounds is $\mathrm{Na}_{3} \mathrm{Y}\{\boldsymbol{u B}, 2 \boldsymbol{r}\}\left[\mathrm{Si}_{6} \mathrm{O}_{15}\right]$ [55]. The structure of its silicate anion is represented in Fig. $8 \mathrm{a}$ and is formed by two dreier rings which connect further to form isolated trigonal prisms of $\mathrm{Si}$ atoms and is also consistent with the Zintl-Klemm concept. Considering that the $\mathrm{Na}$ and $\mathrm{Y}$ atoms donate $6 \mathrm{e}^{-}$per formula unit to the six Si atoms, these are converted into $\Psi$-P

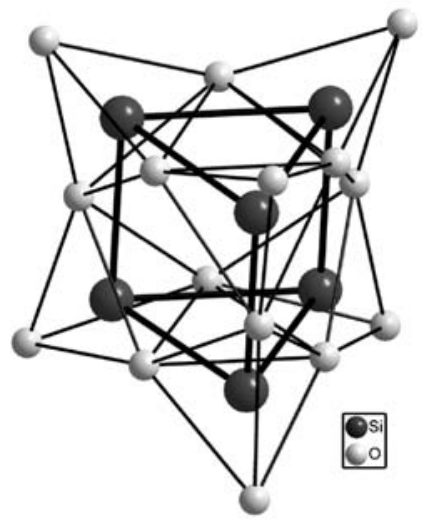

a

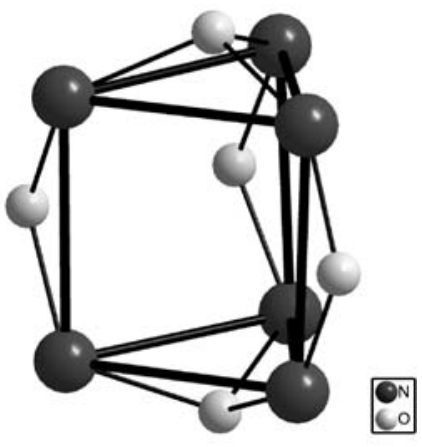

b

Fig. 8 a The structure of the double ring $\left[\mathrm{Si}_{6} \mathrm{O}_{15}\right]^{6-}$ anion existing in $\mathrm{Na}_{3} \mathrm{Y}\{\boldsymbol{u} \boldsymbol{B}, 2 \boldsymbol{r}\}$ $\left[\mathrm{Si}_{6} \mathrm{O}_{15}\right]$. The $\mathrm{Si}$ atoms show a 3 -fold connectivity typical of a $\Psi$-P atom. The $\mathrm{Si}$ atoms form a trigonal prism similar to that formed by the $\mathrm{N}$ atoms in $\mathrm{N}_{6} \mathrm{~S}_{5} \mathbf{b}$ and also similar to the structure of the isoelectronic $\mathrm{Si}_{6} \mathrm{H}_{6}$ (prismane-like) 
atoms which adopt a threefold connectivity, just that occurring in a trigonal prism. Once more, the $\mathrm{O}$ atoms are situated close to both, the midpoints of the hypothetical $\mathrm{Si}-\mathrm{Si}$ bonds and the lone pairs of each $\Psi-\mathrm{P}$ atom. This gives rise to the polyanion $\left[\mathrm{Si}_{6} \mathrm{O}_{15}\right]^{6-}$ which is represented in Fig. $8 \mathrm{a}$.

Although none of the $\mathrm{P}$ allotropes has this type of structure, the connectivity is characteristic of a Group 15 element and a similar skeleton is formed by the $\mathrm{N}$ atoms in the binary compound $\mathrm{N}_{6} \mathrm{~S}_{5}$ [56] which is represented in Fig. $8 \mathrm{~b}$. The differences between both compounds refer only to the amount of anions ( $\mathrm{O}$ and $\mathrm{S}$, respectively) added to the $\mathrm{Si}_{6}$ and $\mathrm{N}_{6}$ skeleton, respectively. Thus, in the oxosilicate, all the bonding and lone pairs of the $\Psi$-P atoms are captured by oxygen atoms whereas in the sulfide $\mathrm{N}_{6} \mathrm{~S}_{5}$, three $S$ atoms are located close to the lateral edges of the prism and two additional sulfur atoms are capping the two triangular bases. It should also be mentioned that the isoelectronic $\mathrm{Si}_{6} \mathrm{H}_{6}$ molecule (prismane-like) could be a stable species as derived from theoretical calculations [57].

Another example of this kind of compounds is provided by turkestanite $\mathrm{K}_{<1}(\mathrm{Na}, \mathrm{Ca})_{2} \mathrm{Th}\{\boldsymbol{u} \boldsymbol{B}, 4,2 \boldsymbol{r}\}\left[\mathrm{Si}_{8} \mathrm{O}_{20}\right]$ [13] mentioned in Sect. 2. It contains vierer double rings in which the $\mathrm{Si}$ atoms form an isolated cube, as seen in Fig. 9a. The electron transfer in this compound is also compatible with the Zintl-Klemm concept. The electropositive atoms (K, Na, Ca and Th) provide eight $\mathrm{e}^{-}$per formula unit which convert the eight $\mathrm{Si}$ atoms into $\Psi$-P atoms with a threefold connectivity, typical of the Group 15 elements. Thus, the $\mathrm{Si}$ atoms ( $\Psi$-P atoms) would form three hypothetical two-centre, two-electron

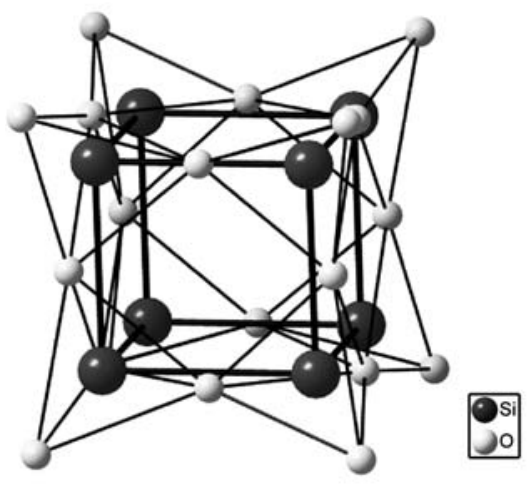

a

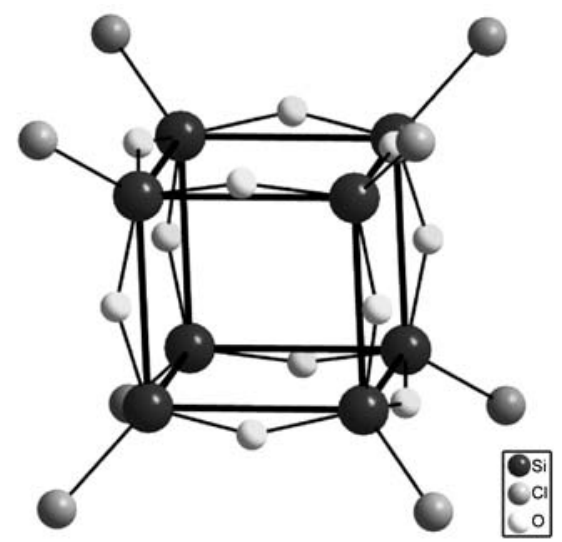

b

Fig. 9 a The structure of the double ring $\left[\mathrm{Si}_{8} \mathrm{O}_{20}\right]^{8-}$ anion existing in turkestanite $\mathrm{K}_{1-x}(\mathrm{Ca}$, $\mathrm{Na}) \mathrm{Th}\{\boldsymbol{u} \boldsymbol{B}, 2 \boldsymbol{r}\}\left[\mathrm{Si}_{8} \mathrm{O}_{20}\right]$. The $\mathrm{Si}$ atoms show a connectivity typical of a $\Psi$-P atom, forming a cube in which the $\mathrm{O}$ atoms are located close to both the midpoints of the $\mathrm{Si}$ - Si bonds and the lone pair regions. The structure is similar to that of the isoelectronic $\mathrm{Si}_{8} \mathrm{O}_{12} \mathrm{Cl}_{8}$ molecule shown in (b) 
$\mathrm{Si}-\mathrm{Si}$ bonds. The $\mathrm{O}$ atoms are then docked close to the midpoints of the edges of the $\left[\mathrm{Si}_{8}\right]$ cubes and also close to the lone pairs of the $\Psi$-P atoms. This type of structure has not been observed in any of the elements of Group 15 of the PSE but it could be a plausible structure for both, the elements and the oxides derived from them. In fact, a similar cage of formula $\mathrm{P}_{4} \mathrm{Si}_{4} \mathbf{R}_{4}(\mathbf{R}=$ t-But) has been isolated [58] in which the $\mathrm{P}_{4} \mathrm{Si}_{4}$ distorted cubes are isoelectronic with the hypothetical $\mathrm{P}_{8}$ molecule if we consider that the two electrons of the $\mathrm{Si}-\mathrm{C}$ bonds are equivalent to lone pairs on the $\mathrm{P}$ atoms. Theoretical studies carried out on the cubane analogues of $\mathrm{Si}$ also show the stability of the $\mathrm{Si}_{8} \mathrm{H}_{8}$ molecule, isoelectronic with the $\mathrm{P}_{8}$ molecule [57]. In connection with this it is also interesting to mention the existence of the compound $\mathrm{Si}_{8} \mathrm{O}_{12} \mathrm{Cl}_{8}$ $\left(\mathrm{Si}_{8} \mathrm{X}_{20}\right)$ [59], even though it is neither a silicate nor a binary oxide. The structure of this silicon oxychloride is represented in Fig. 9b. Here, the Si atoms also form vierer double rings (cubes) and the $\mathrm{O}$ atoms are situated close to the midpoints of the hypothetical $\mathrm{Si}-\mathrm{Si}$ bonds, just at the points where $2 \mathrm{e}^{-}$ are involved in the bonds. The remaining unpaired electron would occupy an empty hybrid orbital, just in the position occupied by the monovalent $\mathrm{Cl}$ atoms.

\section{4}

\section{Chain Silicates}

In Table 5, chain silicates are compiled. They are arranged according to their chain multiplicity into single-, double-, triple-, quadruple- and quintuplechain silicates. Within each of these groups they are arranged with regard to branchedness (unbranched, open-branched and loop-branched), and further according to their chain periodicity $\boldsymbol{P}^{\mathrm{C}}$ (see paragraphs on formula notation in Sect. 2).

\subsection{1}

\section{Single-Chain Silicates}

In the vast number of silicates which contain unbranched single chains, each condensated $\left[\mathrm{SiO}_{4}\right]$ tetrahedron shares two of its four $\mathrm{O}$ atoms with two adjacent tetrahedra. This implies that the infinite chains contain only twoconnected tetrahedra. Following the Zintl-Klemm concept, the electropositive cations, which in the given formulas precede the silicate anion, donate two electrons to each of the Si atoms converting them into $\Psi$-S and giving rise to a twofold connectivity. If the $\mathrm{O}$ atoms are located close to the midpoint of each $\mathrm{Si}-\mathrm{Si}$ bond and also to the two electron lone pairs of each $\mathrm{Si}$ atom, a tetrahedral coordination around the Si atoms is formed. The topology of the skeleton of $\Psi$-S atoms is the same as that of elemental fibrous sulfur. The chain observed in the silicate $\mathrm{Na}_{4}\left[\mathrm{Si}_{2} \mathrm{O}_{6}\right]$ [60] is represented in Fig. 10. The Sichains of the skeleton are identical to those found in some Zintl phases such 
Table 5

\begin{tabular}{|c|c|c|c|c|c|c|c|}
\hline \multirow[b]{2}{*}{ Mineral name } & \multicolumn{2}{|l|}{$\begin{array}{c}\text { Chain silicates } \\
\text { Single-chain silicates } \\
\text { Unbranched single-chain silicates } \\
\left\{\boldsymbol{u} \boldsymbol{B}, 1_{\infty}^{1}\right\} \text { Pseudo- } \mathrm{Si}_{k} \mathrm{P}_{l} \mathrm{~S}_{m} \mathrm{Cl}_{n}\end{array}$} & \multirow{2}{*}{\multicolumn{2}{|c|}{$k l$}} & & \multirow[b]{2}{*}{$n$} & \multirow[b]{2}{*}{ Ref. } \\
\hline & Formula & $P^{\mathrm{C}}$ & & & & & \\
\hline & $\mathrm{Cu}\left[\mathrm{SiO}_{3}\right]$ & 1 & 00 & & 1 & 0 & [271] \\
\hline & $\mathbf{A}_{4}\left[\mathrm{Si}_{2} \mathrm{O}_{6}\right]$ with $\mathbf{A}=\mathrm{Li}, \mathrm{Na}, \mathrm{Ag}$ & 2 & 00 & & 2 & 0 & {$[272 a-c]$} \\
\hline & $\mathrm{Ba}_{2}\left[\mathrm{Si}_{2} \mathrm{O}_{6}\right]$ & 2 & 00 & & 2 & 0 & {$[273]$} \\
\hline & $\mathrm{Li}_{2}(\mathrm{Mg}, \mathrm{Cu}) \mathrm{Cu}_{2}\left[\mathrm{Si}_{2} \mathrm{O}_{6}\right]_{2}$ & 2 & 00 & 0 & 2 & 0 & {$[274]$} \\
\hline Ramsayite & $\mathrm{Na}_{2} \mathrm{Ti}_{2}\left[\mathrm{Si}_{2} \mathrm{O}_{6}\right] \mathrm{O}_{3}$ & 2 & 00 & 0 & 2 & 0 & {$[275]$} \\
\hline $\begin{array}{l}\text { Clinopyroxenes, e.g. } \\
\text { spodumene, jadeite, } \\
\text { aegirine, diopside, } \\
\text { hedenbergite }\end{array}$ & $\begin{array}{l}\text { A A }^{\prime}\left[\mathrm{Si}_{2} \mathrm{O}_{6}\right] \text { with } \mathrm{A}=\mathrm{Li}, \mathrm{Na}, \mathrm{Mg}, \mathrm{Ca} \\
\mathrm{Mn}, \mathrm{Fe}(\mathrm{II}), \mathrm{Zn} ; \mathbf{A}^{\prime}=\mathrm{Mg}, \mathrm{Ca}, \mathrm{Al} \text {, } \\
\text { Ga, Sc, V, Fe(III) }\end{array}$ & 2 & 00 & 0 & 2 & 0 & \\
\hline $\begin{array}{l}\text { Orthopyroxenes, e.g. } \\
\text { enstatite, ferrosilite }\end{array}$ & $\mathrm{MgA}\left[\mathrm{Si}_{2} \mathrm{O}_{6}\right]$ with $\mathrm{A}=\underline{\mathrm{Mg}}, \mathrm{Mn}, \underline{\mathrm{Fe}(\mathrm{II})}$ & 2 & 00 & 0 & 2 & 0 & \\
\hline Pectolite & $\mathrm{HNaCa}_{2}\left[\mathrm{Si}_{3} \mathrm{O}_{9}\right]$ & 3 & 00 & 0 & 3 & 0 & {$[276]$} \\
\hline $\begin{array}{l}\text { Wollastonite, } \\
\text { parawollastonite }\end{array}$ & $\mathrm{Ca}_{3}\left[\mathrm{Si}_{3} \mathrm{O}_{9}\right]$ & 3 & 00 & 0 & 3 & 0 & [277a-b] \\
\hline Sørensenite & $\mathrm{Na}_{4} \mathrm{Be}_{2} \mathrm{Sn}\left[\mathrm{Si}_{3} \mathrm{O}_{9}\right]_{2}\left(\mathrm{H}_{2} \mathrm{O}\right)_{2}$ & 3 & 00 & 0 & 3 & 0 & {$[278]$} \\
\hline Batisite & $\mathrm{Na}_{2} \mathrm{BaTi}_{2}\left[\mathrm{Si}_{4} \mathrm{O}_{12}\right] \mathrm{O}_{2}$ & 4 & 00 & 0 & 4 & 0 & [279] \\
\hline Haradaite, suzukiite & $\mathbf{A}_{2} \mathrm{~V}(\mathrm{IV})_{2}\left[\mathrm{Si}_{4} \mathrm{O}_{12}\right] \mathrm{O}_{2}$ with $\mathrm{A}=\mathrm{Sr}, \mathrm{Ba}$ & 4 & 00 & 0 & 4 & 0 & {$[280 \mathrm{a}-\mathrm{b}]$} \\
\hline Rhodonite & $(\mathrm{Mn}, \mathrm{Ca}, \mathrm{Mg}, \mathrm{Fe})_{5}\left[\mathrm{Si}_{5} \mathrm{O}_{15}\right]$ & 5 & 00 & 0 & 5 & 0 & [281] \\
\hline Santaclaraite & $\mathrm{HCaMn}_{4}\left[\mathrm{Si}_{5} \mathrm{O}_{15}\right](\mathrm{OH})\left(\mathrm{H}_{2} \mathrm{O}\right)$ & 5 & 00 & 0 & 5 & 0 & {$[282]$} \\
\hline Gaidonnayite & $\mathrm{Na}_{4} \mathrm{Zr}_{2}\left[\mathrm{Si}_{6} \mathrm{O}_{18}\right]\left(\mathrm{H}_{2} \mathrm{O}\right)_{4}$ & 6 & 00 & 0 & 6 & 0 & [283] \\
\hline \multirow[t]{2}{*}{ Penkvilksite } & $\mathrm{Na}_{4} \mathrm{Ti}_{2}\left[\mathrm{Si}_{6} \mathrm{O}_{18}\right]\left(\mathrm{H}_{2} \mathrm{O}\right)_{4}$ & 6 & 00 & 0 & 6 & 0 & {$[284]$} \\
\hline & $\mathrm{K}_{4} \mathbf{A}_{2}\left[\mathrm{Si}_{6} \mathrm{O}_{18}\right]$ with $\mathbf{A}=\mathrm{Ti}, \mathrm{Sn}$ & 6 & 00 & 0 & 6 & 0 & {$[285]$} \\
\hline Pyroxmangite & $\mathrm{Mn}_{7}\left[\mathrm{Si}_{7} \mathrm{O}_{21}\right]$ & 7 & 00 & 0 & 7 & 0 & [286] \\
\hline \multirow[t]{2}{*}{ (Ferrosilite III) } & $\mathrm{Fe}_{9}\left[\mathrm{Si}_{9} \mathrm{O}_{27}\right]$ & 9 & 00 & 0 & 9 & 0 & [287] \\
\hline & $\mathrm{Cs}_{6} \mathrm{Sb}_{6}\left[\mathrm{Si}_{12} \mathrm{O}_{36}\right] \mathrm{O}_{6}$ & 12 & 00 & 01 & 12 & 0 & [288] \\
\hline \multirow[t]{3}{*}{ Alamosite } & $\mathrm{Pb}_{12}\left[\mathrm{Si}_{12} \mathrm{O}_{36}\right]$ & 12 & 00 & 01 & 12 & 0 & [289] \\
\hline & $\mathrm{Na}_{24} \mathrm{Y}_{8}\left[\mathrm{Si}_{24} \mathrm{O}_{72}\right]$ & 24 & 00 & 02 & 24 & 0 & [290] \\
\hline & $\begin{array}{l}\text { Open-branched single-chain silicates } \\
\left\{\boldsymbol{o} B, 1_{\infty}^{1}\right\} \text { Pseudo- } \mathrm{Si}_{k} \mathrm{P}_{l} \mathrm{~S}_{m} \mathrm{Cl}_{n}\end{array}$ & & & & & & \\
\hline Astrophyllite & $\begin{array}{l}\mathrm{NaK}_{2} \mathrm{Mg}_{2}(\mathrm{Fe}, \mathrm{Mn})_{5} \mathrm{Ti}_{2}\left[\mathrm{Si}_{4} \mathrm{O}_{12}\right]_{2} \\
(\mathrm{O}, \mathrm{OH}, \mathrm{F})_{7}\end{array}$ & 2 & 02 & 2 & 0 & 2 & [291] \\
\hline \multirow{3}{*}{ Aenigmatite } & $\mathrm{Eu}_{2}\left[\mathrm{Si}^{\lceil 1 ; 4]} \mathrm{P}_{2}^{\lceil 1 ; 2\rfloor} \mathrm{P}_{2}^{\lceil 1 ; 1\rfloor} \mathrm{O}_{15}\right]$ & 3 & 10 & 0 & 2 & 2 & [292] \\
\hline & $\mathrm{Na}_{2} \mathrm{~A}_{6}\left[\mathrm{Si}_{6} \mathrm{O}_{18}\right](\mathrm{O}, \mathrm{OH})_{2}$ & & & & & & \\
\hline & with $\mathrm{A}=\mathrm{Mg},(\mathrm{Mg}, \mathrm{Fe}),(\mathrm{Fe}, \mathrm{Ti})$ & 4 & 02 & 2 & 2 & 2 & {$[293 a-c]$} \\
\hline \multirow[t]{3}{*}{ Saneroite } & $\mathrm{HNa}_{2-x} \mathrm{Mn}_{5}\left[\mathrm{Si}_{5}(\mathrm{Si}, \mathrm{V}) \mathrm{O}_{18}\right](\mathrm{OH})_{2}$ & 5 & 01 & 1 & 4 & 1 & [294] \\
\hline & $\begin{array}{l}\text { Loop-branched single-chain silicates } \\
\quad\left\{l B, 1_{\infty}^{1}\right\} \text { Pseudo- } \mathrm{Si}_{k} \mathrm{P}_{l} \mathrm{~S}_{m} \mathrm{Cl}_{n}\end{array}$ & & & & & & \\
\hline & $\mathrm{Li}_{2} \mathrm{Mg}_{2}\left[\mathrm{Si}_{4} \mathrm{O}_{11}\right]$ & 3 & 02 & 2 & 2 & 0 & [295] \\
\hline
\end{tabular}

continued on next page 
Table 5 (continued)

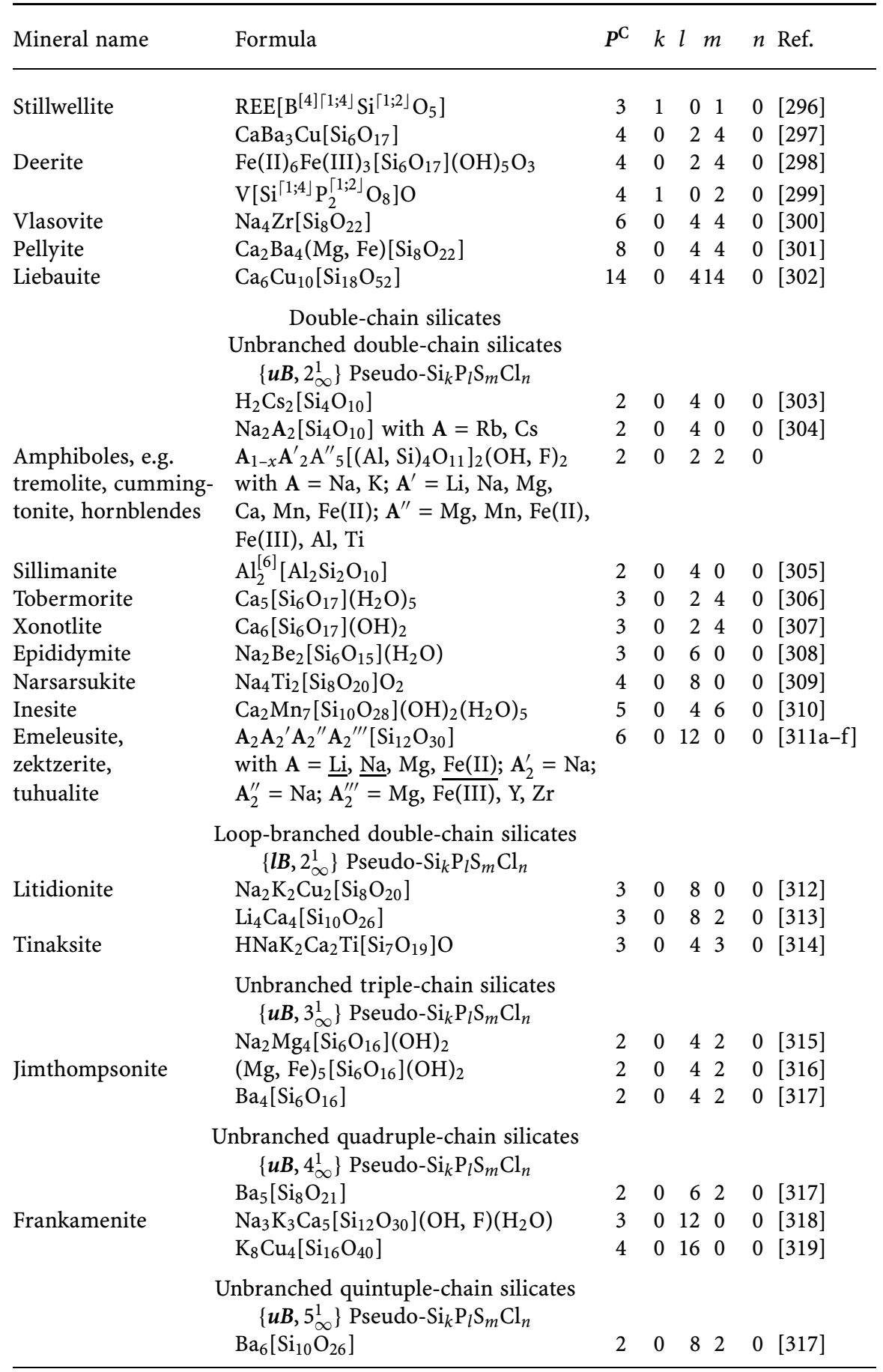




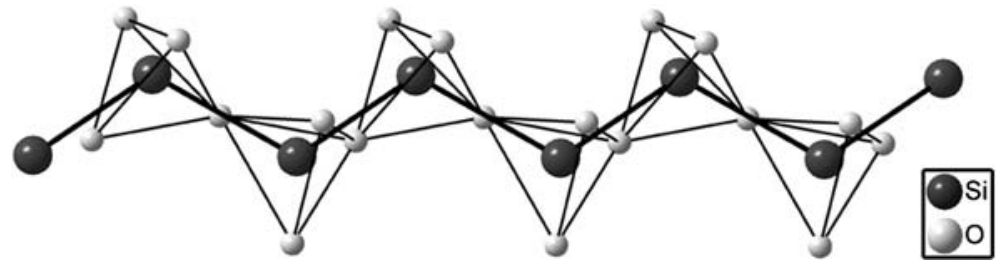

Fig. 10 The structure of an unbranched single chain anion existing in $\operatorname{Na}_{4}\left\{\boldsymbol{u} B, 2,1_{\infty}^{1}\right\}$ $\left[\mathrm{Si}_{2} \mathrm{O}_{6}\right]$, to show its similarity with the chains of fibrous sulfur and with the asbestos-like $\mathrm{SO}_{3}$ oxide

as $\mathrm{BaSi}[61]$ where the $\mathrm{Si}$ atoms can also be regarded as $\Psi$-S. In fact, the $\mathrm{BaSi}$ substructure, in the HT phase of $\mathrm{Ba}_{2}\left[\mathrm{Si}_{2} \mathrm{O}_{6}\right]$ [62], is almost identical to the structure of $\mathrm{BaSi}$ itself, so that $\mathrm{Ba}_{2}\left[\mathrm{Si}_{2} \mathrm{O}_{6}\right]$ is an example of the so-called real stuffed alloys [63].

The structure of the loop-branched single chain observed in vlasovite $\mathrm{Na}_{4} \mathrm{Zr}_{2}\left\{\boldsymbol{l B}, 6,1_{\infty}^{1}\right\}\left[\mathrm{Si}_{8} \mathrm{O}_{22}\right]$ [64] is presented in Fig. 11a. Sodium and zirconium atoms transfer 12 electrons per formula unit to the eight silicon atoms, transforming four of them into $\Psi$-P and four into $\Psi$-S. The resulting pseudostoichiometry is $\Psi$-PS. This kind of chain is also observed in the roomtemperature polymorph of the Zintl phase $\mathrm{Ba}_{3} \mathrm{Ge}_{4}$ [65]. In this compound, the
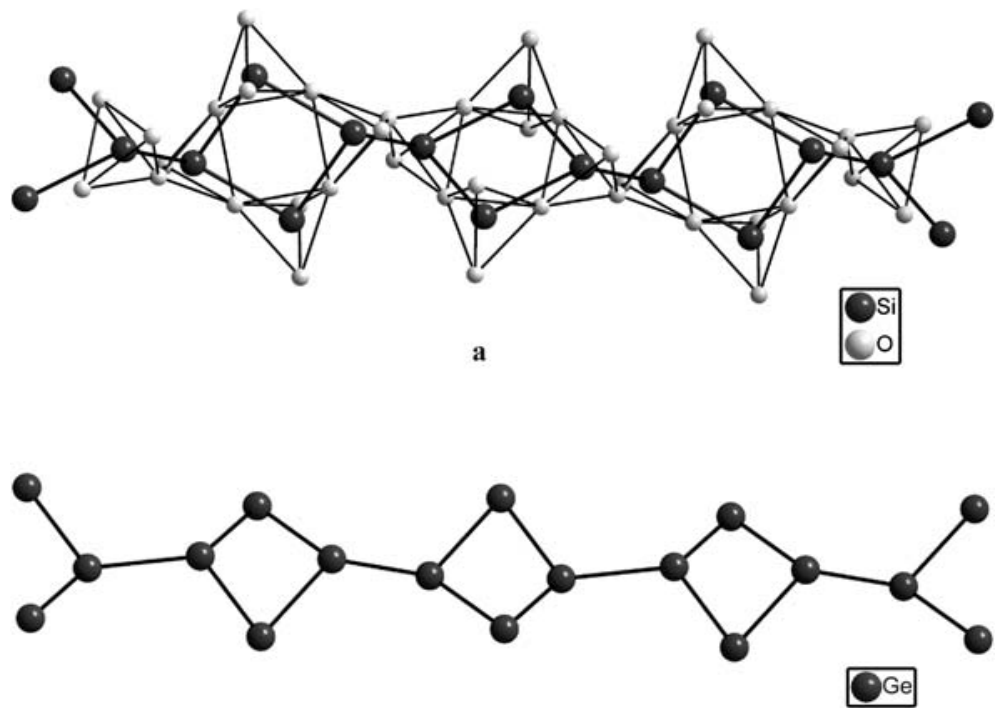

b

Fig. 11 a View of the loop-branched single chain in vlasovite $\mathrm{Na}_{4} \mathrm{Zr}_{2}\left\{\boldsymbol{l B}, 6,1_{\infty}^{1}\right\}\left[\mathrm{Si}_{8} \mathrm{O}_{22}\right]$. The chain is composed of $\Psi$-P and $\Psi$-S pseudo-atoms in the ratio $1: 1$. b The same type of chain is formed by the $\mathrm{Ge}$ atoms in the Zintl phase $\mathrm{Ba}_{3} \mathrm{Ge}_{4}$ 
three $\mathrm{Ba}$ atoms donate six electrons per formula unit to the $\mathrm{Ge}$ atoms converting two of them into $\Psi$-As and the other two into $\Psi$-Se atoms. The final pseudo-stoichiometry is $\Psi$-AsSe, adopting a structure in which butterfly-like $\left[\mathrm{Ge}_{4}\right]^{6-}$ anions ( $\Psi$-AsSe) and vlasovite-like chains (also $\Psi$-AsSe) coexist (see Fig. 11b).

An example of an open-branched chain silicate is the mineral aenigmatite $\mathrm{Na}_{2} \mathrm{Fe}_{5} \mathrm{Ti}\left\{\boldsymbol{o B}, 4,1_{\infty}^{1}\right\}\left[\mathrm{Si}_{6} \mathrm{O}_{18}\right] \mathrm{O}_{2}$ [66] (see Fig. 12a). In this case, the $\mathrm{Na}, \mathrm{Fe}$ and Ti atoms donate 16 electrons per formula unit. Of them, 4 are directly transferred to two $\mathrm{O}$ atoms not bonded to silicon and the remaining 12 electrons go to the Si skeleton, converting two Si atoms into $\Psi$-P, two Si atoms into $\Psi$-S and two $\mathrm{Si}$ atoms into $\Psi$-Cl atoms. The final pseudo-formula would be $\Psi$ $\mathrm{P}_{2} \mathrm{~S}_{2} \mathrm{Cl}_{2}$ ( $\Psi$-PSCl). Although there is no known Zintl phase with this type of structure, there are several compounds $\left(\mathrm{NaAsS}_{2}, \mathrm{NaAsSe}_{2}, \ldots\right)[67,68]$ which have the same pseudo-stoichiometry, and they only differ slightly from aenigmatite in their atom arrangement. As can be seen in Fig. 12b, in the Zintl phases, every second atom of the stem of the chain carries a branch atom, whereas in the silicate two adjacent tetrahedra, each carrying a branch, alternate with the two tetrahedra without a branch. The chain periodicities, therefore, are $P^{\mathrm{C}}=2$ and 4 for the Zintl phases and the silicate, respectively.

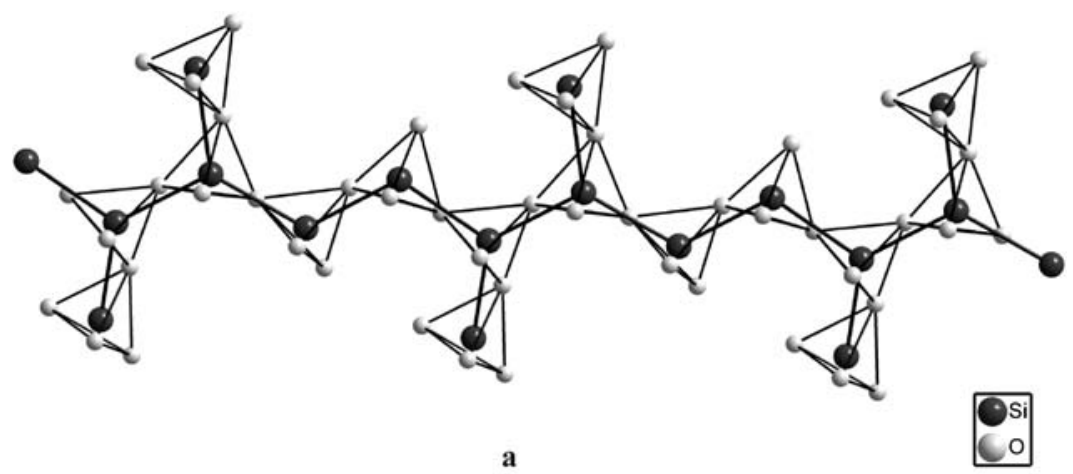

a

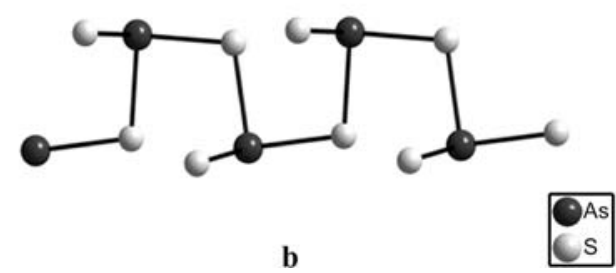

Fig. 12 a The open-branched silicate chain in aenigmatite $\mathrm{Na}_{2} \mathrm{Fe}_{5} \mathrm{Ti}\left\{\boldsymbol{o} B, 4,1_{\infty}^{1}\right\}\left[\mathrm{Si}_{6} \mathrm{O}_{18}\right] \mathrm{O}_{2}$. The $\mathrm{Si}$ atoms behave as $\Psi$-P, $\Psi$-S and $\Psi$-Cl leading to the pseudo-stoichiometry $\Psi$ PSCl. b The strongly related chain formed by the Zintl polyanion $\mathrm{AsS}_{2}^{-}$(also $\Psi$-PSCl) in $\mathrm{NaAsS}_{2}$ 


\subsection{2}

\section{Double-Chain Silicates}

Because amphiboles form one of the most abundant mineral groups, tremolite $\mathrm{Ca}_{2} \mathrm{Mg}_{5}\left\{\boldsymbol{u} \boldsymbol{B}, 2,2{ }_{\infty}^{1}\right\}\left[\mathrm{Si}_{8} \mathrm{O}_{22}\right](\mathrm{OH})_{2}$ [12] is used to demonstrate the application of the Zintl-Klemm concept to unbranched zweier double chain silicates. The silicate anion of the amphibole is represented in Fig. 13a. In it, one half of its $\mathrm{T}$ atoms are three-connected and the other half two-connected. In this case, the $\mathrm{Ca}$ and $\mathrm{Mg}$ atoms together provide $14 \mathrm{e}^{-}$per formula unit. Two of them are transferred directly to the hydroxyl groups and the remaining $12 \mathrm{e}^{-}$should be transferred to the eight $\mathrm{Si}$ atoms, converting one half of them into $\Psi$-P (three-connected) and the other half into $\Psi$-S (twoconnected). The result is an anion with a pseudo-stoichiometry $\Psi$-PS whose formula and structure are coincident with that observed in the Zintl polyanion $\left[\mathrm{Sb}_{2}\right]^{-}$in the Zintl phase $\mathrm{KSb}_{2}$ [69]. This polyanion is represented in Fig. 13b. It is worth mentioning that this silicate anion can also be derived from the structure of As [70] in which the puckered layers are broken into fragments as a consequence of transforming one half of the atoms into $\Psi$-S. In fact, the double chain structure of the silicate resembles fragments of the chair-conformed layers of As.
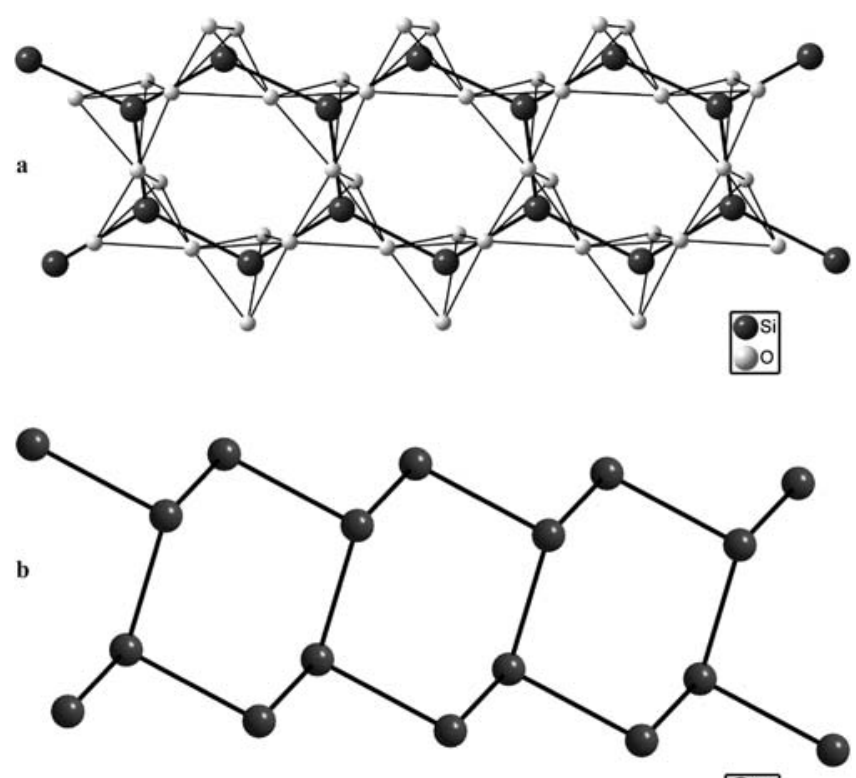

OSb

Fig. 13 (a) The double chain formed by the $\left[\mathrm{SiO}_{4}\right]$ tetrahedra in the amphibole tremolite, $\mathrm{Ca}_{2} \mathrm{Mg}_{5}\left\{u B, 2,2_{\infty}^{1}\right\}\left[\mathrm{Si}_{8} \mathrm{O}_{22}\right](\mathrm{OH})_{2}$. The $\mathrm{T}$ atom skeleton is similar to that of the $\mathrm{Sb}$ atoms in the Zintl phase $\mathrm{KSb}_{2}$, represented in (b) 


\section{5}

\section{Layer Silicates}

\subsection{1}

\section{Single-Layer Silicates}

To this family of compounds belong the silicates which contain infinite twodimensional layers of corner-sharing $\left[\mathrm{SiO}_{4}\right]$ tetrahedra. The layers contain $\mathrm{n}$-membered rings, where $\mathrm{n}$ varies from $3,4,5,6,8$ to 10 and more. In a few compounds, rings of different size coexist in the structure. Known ternary and quaternary compounds of this family are listed in Table 6 and divided into groups according to the branchedness and periodicity of the fundamental chains forming the layers.

\subsubsection{1}

\section{Silicon as Pseudo-P}

We begin with compounds of stoichiometry $\mathbf{A}_{2}\left[\mathrm{Si}_{2} \mathrm{O}_{5}\right]$. If we assume that two electrons per formula unit are transferred to the two Si atoms, these will be converted into pseudo-elements of the Group 15 of the PSE. In this way, a threefold connectivity is to be expected by applying the 8-N rule.

Thus, in $\mathrm{Li}_{2}\left[\mathrm{Si}_{2} \mathrm{O}_{5}\right](P b c n, C c c 2)$ [71,72] and in $\mathrm{Na}_{2}\left[\mathrm{Si}_{2} \mathrm{O}_{5}\right](\alpha: P b c n$, $\left.\beta: P 2_{1} / a\right)[73,74]$, the $\mathrm{Si}$ atoms adopt structures formed by layers of chair conformed six-membered rings, similar to those existing in elemental As [70], GeS [75] or the As skeleton in claudetite, the monoclinic phase of $\mathrm{As}_{2} \mathrm{O}_{3}$ [34]. If we consider the existence of these $\mathrm{Si}-\mathrm{Si}$ bonds, three $\mathrm{O}$ atoms would be inserted close to the midpoints of the three $\mathrm{Si}-\mathrm{Si}$ bonds. The fourth $\mathrm{O}$ atom would be situated close to the lone pair of the $\Psi$-P atoms. In this way, the tetrahedral coordination of silicon by the $\mathrm{O}$ atoms is obtained. This layer is represented in Fig. 14a to be compared with the layer of the As structure represented in Fig. 14b. Topologically identical layers with only three-connected tetrahedra which, however, contain either planar or boat conformed six-membered rings are present in some phyllosilicates, such as kaolinite, talc, pyrophyllite, sepiolite, etc ..., and in three other polymorphs of $\mathrm{Na}_{2}\left[\mathrm{Si}_{2} \mathrm{O}_{5}\right]\left(\delta: P 2_{1} / n, \varepsilon: P b c 2_{1}, \mathrm{C}: P 2_{1} / c\right)$ [76-78] (see Table 6).

\subsubsection{2}

\section{The Pseudo- $\mathrm{P}_{2} \mathrm{~S}_{3}$ Structure}

Another structure to be discussed is that of $\mathrm{La}_{3} \mathrm{Ga}^{[6]}\left[\mathrm{Ga}_{3}^{[4]\lceil 1 ; 2\rfloor} \mathrm{Ga}^{[4]\lceil 1 ; 3\rfloor}\right.$ $\left.\mathrm{Si}^{[4][1 ; 3\rfloor} \mathrm{O}_{14}\right]$ [79]. The structure contains one hexa-coordinated $\mathrm{Ga}$ atom per formula unit, whereas the other four $\mathrm{Ga}$ atoms and the Si atom are tetracoordinated (the so called $\mathrm{T}$ atoms). The electron transfer which justifies 
Table 6

\begin{tabular}{|c|c|c|c|c|c|c|}
\hline Mineral name & $\begin{array}{c}\text { Layer silicates } \\
\text { Single-layer silicates } \\
\text { Unbranched single-layer silicates } \\
\left\{u \boldsymbol{B}, 1_{\infty}^{2}\right\} \text {, Pseudo- } \mathrm{Si}_{k} \mathrm{P}_{l} \mathrm{~S}_{m} \mathrm{Cl}_{n} \\
\text { Formula }\end{array}$ & $P^{\mathrm{C}}$ & $k$ & $l$ & $m n$ & Ref. \\
\hline & $\mathrm{HA}\left[\mathrm{Si}_{2} \mathrm{O}_{5}\right]$ with $\mathbf{A}=\mathrm{H}, \mathrm{K}, \mathrm{Rb}, \mathrm{Cs}$ & 2 & 0 & 2 & 00 & {$[320 a-c]$} \\
\hline \multirow[t]{2}{*}{ Kanemite } & $\mathrm{HNa}\left[\mathrm{Si}_{2} \mathrm{O}_{5}\right]\left(\mathrm{H}_{2} \mathrm{O}\right)_{3}$ & 2 & 0 & 2 & 00 & {$[321]$} \\
\hline & $\mathrm{Li} \mathbf{A}\left[\mathrm{Si}_{2} \mathrm{O}_{5}\right]^{*}$ with $\mathrm{A}=\mathrm{Li}, \mathrm{K}$ & 2 & 0 & 2 & 00 & {$[322 a-c]$} \\
\hline \multirow{2}{*}{ Petalite } & $\operatorname{LiAl}\left[\mathrm{Si}_{4} \mathrm{O}_{10}\right]^{*}$ & 2 & 0 & 2 & 00 & {$[323]$} \\
\hline & $\mathrm{K}_{2}\left[\mathrm{Si}_{4} \mathrm{O}_{9}\right](\mathrm{LP})$ & 2 & 2 & 2 & 00 & {$[324]$} \\
\hline \multirow{6}{*}{$\begin{array}{l}\text { Micas, e.g. annite, } \\
\text { muscovite } \\
\text { Talc } \\
\text { Sanbornite } \\
\text { Kaolinite, nacrite, } \\
\text { dickite }\end{array}$} & $\mathrm{KFe}(\mathrm{II})_{3}\left[\mathrm{AlSi}_{3} \mathrm{O}_{10}\right](\mathrm{OH})_{2}$ & 2 & 0 & 4 & 00 & [325] \\
\hline & $\mathrm{KAl}_{3}\left[\mathrm{AlSi}_{3} \mathrm{O}_{10}\right](\mathrm{OH})_{2}$ & 2 & 0 & 4 & 00 & {$[326]$} \\
\hline & $\mathrm{Mg}_{3}\left[\mathrm{Si}_{2} \mathrm{O}_{5}\right]_{2}(\mathrm{OH})_{2}$ & 2 & 0 & 2 & 00 & {$[327]$} \\
\hline & $\mathrm{Ba}\left[\mathrm{Si}_{2} \mathrm{O}_{5}\right]$ & 2 & 0 & 2 & 00 & {$[328]$} \\
\hline & $\mathrm{Al}_{2}\left[\mathrm{Si}_{2} \mathrm{O}_{5}\right](\mathrm{OH})_{4}$ & 2 & 0 & 2 & 00 & {$[329 a-c]$} \\
\hline & $\mathrm{Na}_{3} \mathrm{~K}_{3}\left[\mathrm{Si}_{6} \mathrm{O}_{15}\right]$ & 3 & 0 & 6 & 00 & {$[330]$} \\
\hline \multirow[t]{2}{*}{ Apophyllite } & $\begin{array}{l}\mathrm{ACa}_{4}\left[\mathrm{Si}_{8} \mathrm{O}_{20}\right] \mathbf{X}\left(\mathrm{H}_{2} \mathrm{O}\right)_{8} \\
\text { with } \mathrm{A}=\mathrm{Na}, \mathrm{K} ; \mathbf{X}=\mathrm{F}, \mathrm{OH}\end{array}$ & 4 & 0 & 8 & 00 & {$[331]$} \\
\hline & $\mathrm{Na}_{4} \mathrm{Zn}_{2}\left[\mathrm{Si}_{6} \mathrm{O}_{16}\right]^{*}$ & 3 & 0 & 4 & 20 & {$[332]$} \\
\hline \multirow[t]{2}{*}{ Pentvilksite } & $\mathrm{Na}_{4} \mathrm{Ti}_{2}\left[\mathrm{Si}_{8} \mathrm{O}_{22}\right]\left(\mathrm{H}_{2} \mathrm{O}\right)_{4}$ & 4 & 0 & 4 & 40 & [333] \\
\hline & $\mathrm{K}_{2} \mathrm{Ba}_{7}\left[\mathrm{Si}_{8} \mathrm{O}_{20}\right]_{2}$ & 4 & 0 & 8 & 00 & {$[334]$} \\
\hline Davanite, dalyite & $\mathrm{K}_{2} \mathrm{~A}\left[\mathrm{Si}_{6} \mathrm{O}_{15}\right]$ with $\mathrm{A}=\underline{\mathrm{Ti}}, \underline{\mathrm{Zr}}$ & 3 & 0 & 6 & 00 & [335] \\
\hline $\begin{array}{l}\text { Cuprorivaite, wessel- } \\
\text { site, effenbergerite }\end{array}$ & $\mathrm{A}_{2} \mathrm{Cu}_{2}\left[\mathrm{Si}_{8} \mathrm{O}_{20}\right]$ with $\mathrm{A}=\underline{\mathrm{Ca}}, \underline{\mathrm{Sr}}, \underline{\mathrm{Ba}}$ & 4 & 0 & 8 & 00 & {$[336 a-c]$} \\
\hline \multirow[t]{3}{*}{ Ekanite } & $\mathrm{Ca}_{2} \mathrm{Th}\left[\mathrm{Si}_{8} \mathrm{O}_{20}\right]$ & 4 & 0 & 8 & 00 & [337] \\
\hline & $\mathrm{LiBa}_{9}\left[\mathrm{Si}_{10} \mathrm{O}_{25}\right] \mathrm{Cl}_{7}\left(\mathrm{CO}_{3}\right)$ & 5 & 01 & 10 & 00 & {$[338]$} \\
\hline & $\mathrm{K}_{12}\left[\mathrm{Si}_{12} \mathrm{O}_{30}\right]$ & 6 & 01 & 12 & 00 & {$[322 b]$} \\
\hline Manganpyrosmalite & $(\mathrm{Mn}, \mathrm{Fe})_{16}\left[\mathrm{Si}_{12} \mathrm{O}_{30}\right](\mathrm{OH})_{17} \mathrm{Cl}_{3}$ & 6 & 01 & 12 & 00 & [339] \\
\hline & $\begin{array}{l}\text { Open-branched single-layer silicate } \\
\quad\left\{\boldsymbol{o B}, 1_{\infty}^{2}\right\} \text { Pseudo- } \mathrm{Si}_{k} \mathrm{P}_{l} \mathrm{~S}_{m} \mathrm{Cl}_{n}\end{array}$ & & & & & \\
\hline Prehnite & $\mathrm{Ca}_{2}(\mathrm{Al}, \mathrm{Fe})\left[\mathrm{AlSi}_{3} \mathrm{O}_{10}\right](\mathrm{OH})_{2}$ & 2 & 2 & 0 & 20 & {$[340]$} \\
\hline Kvanefjeldite & $\mathrm{H}_{2} \mathrm{Na}_{4}(\mathrm{Ca}, \mathrm{Mn})\left[\mathrm{Si}_{6} \mathrm{O}_{16}\right]$ & 4 & 0 & 4 & 20 & {$[341]$} \\
\hline \multirow[t]{7}{*}{ Zeophyllite } & $\mathrm{Ca}_{13}\left[\mathrm{Si}_{5} \mathrm{O}_{14}\right]_{2} \mathrm{~F}_{10}\left(\mathrm{H}_{2} \mathrm{O}\right)_{6}$ & 4 & 0 & 2 & 30 & {$[342]$} \\
\hline & $\mathrm{La}_{3} \mathrm{Ga}^{[6]}\left[\mathrm{Ga}_{4} \mathrm{SiO}_{14}\right]$ & 4 & 0 & 2 & 30 & {$[343]$} \\
\hline & $\begin{array}{l}\text { Loop-branched single-layer silicate } \\
\qquad\left\{\boldsymbol{l} B, 1_{\infty}^{2}\right\} \text { Pseudo- } \mathrm{Si}_{k} \mathrm{P}_{l} S_{m} \mathrm{Cl}_{n}\end{array}$ & & & & & \\
\hline & $\mathrm{Na}_{6}\left[\mathrm{Si}_{8} \mathrm{O}_{19}\right]$ & 2 & 2 & 6 & 00 & {$[344]$} \\
\hline & $\mathrm{NaA}\left[\mathrm{Si}_{6} \mathrm{O}_{14}\right]$ with $\mathrm{A}=\mathrm{Pr}, \mathrm{Nd}$ & 4 & 2 & 4 & 00 & [345] \\
\hline & $\mathrm{K}_{4} \mathrm{Sb}_{2}\left[\mathrm{Si}_{8} \mathrm{O}_{20}\right](\mathrm{OH})_{2}$ & 3 & 0 & 8 & 00 & {$[346]$} \\
\hline & $\mathrm{K}_{2} \mathrm{Ge}\left[\mathrm{Si}_{6} \mathrm{O}_{15}\right]$ & 4 & 0 & 6 & 00 & [347] \\
\hline \multirow[t]{3}{*}{ Zussmanite } & $\mathrm{KFe}_{13}\left[\mathrm{AlSi}_{17} \mathrm{O}_{42}\right](\mathrm{OH})_{4}$ & 5 & 61 & 12 & 00 & [348] \\
\hline & $\mathrm{K}_{8} \mathrm{Yb}_{3}\left[\mathrm{Si}_{6} \mathrm{O}_{16}\right]_{2}(\mathrm{OH})$ & 5 & 0 & 4 & 20 & [349] \\
\hline & $\mathrm{K}_{2} \mathrm{Eu}(\mathrm{II})_{4}\left[\mathrm{Si}_{8} \mathrm{O}_{20}\right] \mathrm{F}_{2}$ & 6 & 0 & 8 & 00 & {$[350]$} \\
\hline
\end{tabular}

continued on next page 
Table 6 (continued)

\begin{tabular}{|c|c|c|c|c|c|c|}
\hline Mineral name & Formula & $P^{\mathrm{C}}$ & $k$ & & $n n$ & Ref. \\
\hline \multirow{4}{*}{$\begin{array}{l}\text { Dmisteinbergite, } \\
\text { cymrite }\end{array}$} & $\begin{array}{c}\text { Double-layer silicates } \\
\text { Unbranched double-layer silica } \\
\left\{u B, 2_{\infty}^{2}\right\} \text { Pseudo- } \mathrm{Si}_{k} \mathrm{P}_{l} \mathrm{~S}_{m} \mathrm{Cl}_{n}\end{array}$ & & & & & \\
\hline & $\begin{array}{l}\mathrm{A}\left[\mathrm{Al}_{2} \mathrm{Si}_{2} \mathrm{O}_{8}\right]\left(\mathrm{H}_{2} \mathrm{O}\right)_{1-x} \\
\text { with } \mathrm{A}=\underline{\mathrm{Ca}}, \mathrm{Sr}, \underline{\mathrm{Ba}}\end{array}$ & 2 & 4 & & 0 & [351a-c] \\
\hline & $\begin{array}{l}\text { Open-branched double-layer silic } \\
\left\{\boldsymbol{o B}, 2_{\infty}^{2}\right\} \text { Pseudo- } \mathrm{Si}_{k} \mathrm{P}_{l} \mathrm{~S}_{m} \mathrm{Cl}_{n}\end{array}$ & & & & & \\
\hline & {$\left[\mathrm{C}_{4} \mathrm{H}_{12} \mathrm{~N}_{2}^{2+}\right]\left[\mathrm{Si}_{6} \mathrm{O}_{13}\right]$} & 2 & 4 & 20 & 0 & {$[352]$} \\
\hline \multirow{5}{*}{$\begin{array}{l}\text { Rhodesite } \\
\text { Macdonaldite } \\
\text { Delhayelite }\end{array}$} & $\begin{array}{l}\text { Loop-branched double-layer silic } \\
\left\{l \boldsymbol{l}, 2_{\infty}^{2}\right\} \text { Pseudo- } \mathrm{Si}_{k} \mathrm{P}_{l} \mathrm{~S}_{m} \mathrm{Cl}_{n}\end{array}$ & & & & & \\
\hline & $\mathrm{HKCa}_{2}\left[\mathrm{Si}_{8} \mathrm{O}_{19}\right]\left(\mathrm{H}_{2} \mathrm{O}\right)_{5}$ & 3 & 2 & 60 & 00 & [353] \\
\hline & $\mathrm{H}_{2} \mathrm{Ca}_{4} \mathrm{Ba}\left[\mathrm{Si}_{8} \mathrm{O}_{19}\right]_{2}\left(\mathrm{H}_{2} \mathrm{O}\right)_{10}$ & 3 & 2 & 60 & 00 & {$[354]$} \\
\hline & $\mathrm{Na}_{3} \mathrm{~K}_{7} \mathrm{Ca}_{5}\left[\mathrm{AlSi}_{7} \mathrm{O}_{19}\right]_{2} \mathrm{Cl}_{2} \mathrm{~F}_{4}$ & 3 & 2 & 60 & 00 & {$[355]$} \\
\hline & $\mathrm{Cs}_{3} \mathrm{Sc}\left[\mathrm{Si}_{8} \mathrm{O}_{19}\right]$ & 3 & 2 & 60 & 00 & [356] \\
\hline Carletonite & $\mathrm{KNa}_{4} \mathrm{Ca}_{4}\left[\mathrm{Si}_{8} \mathrm{O}_{18}\right](\mathrm{F}, \mathrm{OH})\left(\mathrm{CO}_{3}\right)_{4}\left(\mathrm{H}_{2} \mathrm{O}\right)$ & 6 & 4 & 40 & 00 & {$[357]$} \\
\hline
\end{tabular}

the observed structure of the gallosilicate layer is summarised in the following scheme:

$$
\begin{aligned}
& \mathrm{La}_{3} \mathrm{Ga}(1) \mathrm{Ga}(2){ }_{3} \mathrm{Ga}(3) \mathrm{SiO}_{14} \\
& \text { Donors: } 3 \mathrm{La} \rightarrow 3 \mathrm{La}^{[8]}+9 \mathrm{e}^{-} \\
& \frac{\mathrm{Ga}(1) \rightarrow \mathrm{Ga}(1)^{[6]}+3 \mathrm{e}^{-}}{12 \mathrm{e}^{-}} \\
& \mathrm{Ga}(3)+2 \mathrm{e}^{-} \rightarrow(\Psi-\mathrm{As})^{[4]\lceil 1 ; 3\rfloor} \\
& \frac{\mathrm{Si} \quad+1 \mathrm{e}^{-} \rightarrow(\Psi-\mathrm{P})^{[4]\lceil 1 ; 3\rfloor}}{12 \mathrm{e}^{-}}
\end{aligned}
$$

Here, the three $\mathrm{La}$ atoms and one of the $\mathrm{Ga}$ atoms act as donors providing 12 electrons. Four of them are used to convert the other four $\mathrm{Ga}$ atoms into $\Psi$-Ge, five additional electrons convert all the $\Psi$-Ge into $\Psi$-As and the three remaining electrons convert three $\Psi$-As into $\Psi$-Se. The final result is a layer of stoichiometry $\Psi$-PAsSe 3 (see Fig. 15a) with three- and two-connected Ga and $\mathrm{Si}$ atoms in the ratio $2: 3$. The layers contain only twelve-membered rings and are comparable to those existing in the Zintl phase $\mathrm{CeP}_{5}[80]$ where the three valence electrons donated by the Ce atoms convert three $\mathrm{P}$ atoms into $\Psi$-S, giving rise to the polyanion $P_{5}^{3-}\left(\Psi-P_{2} S_{3}\right)$. This polyanion is represented in Fig. 15b. As in all the compounds described, the oxygen atoms are situ- 


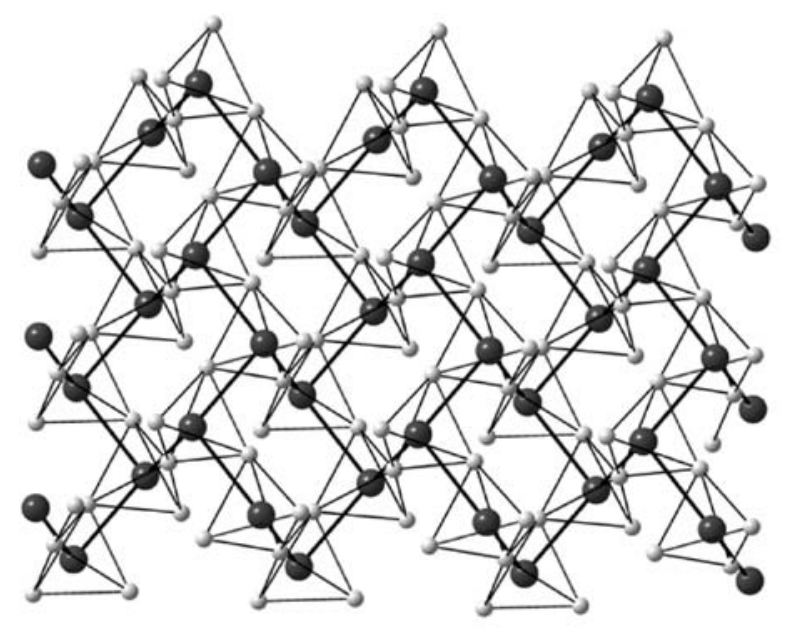

a

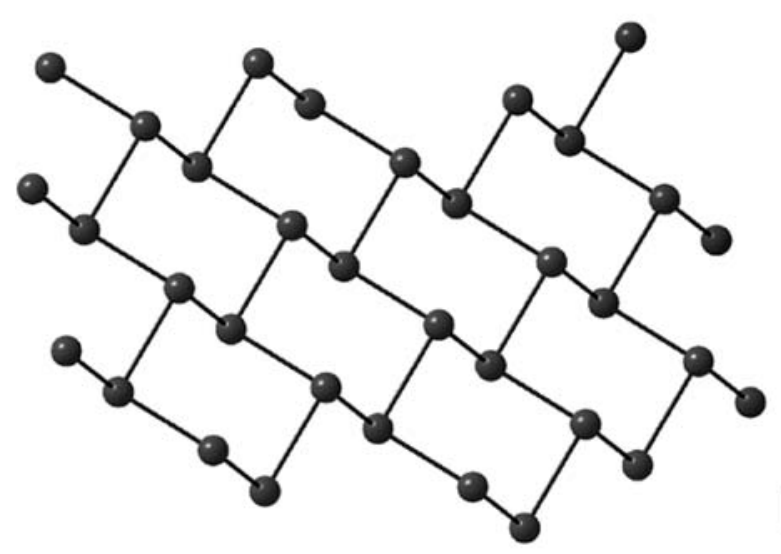

b

Fig. 14 (a) A layer of $\left[\mathrm{Si}_{2} \mathrm{O}_{5}\right]^{2-}$ anions in $\alpha-\mathrm{Na}_{2}\left[\mathrm{Si}_{2} \mathrm{O}_{5}\right]$ (Pbcn) in which the $\mathrm{Si}$ atoms adopt the layer structure of As, drawn in (b)

ated close to bonding and lone electron pairs giving rise to the tetrahedral coordination.

\subsubsection{3}

\section{Dual Role of T Atoms other than Si and Al}

There is an ambiguity whether tetrahedrally coordinated cations $\mathbf{T}$ other than $\mathrm{Si}$ and $\mathrm{Al}$ are considered to be part of the silicate anions or not. 


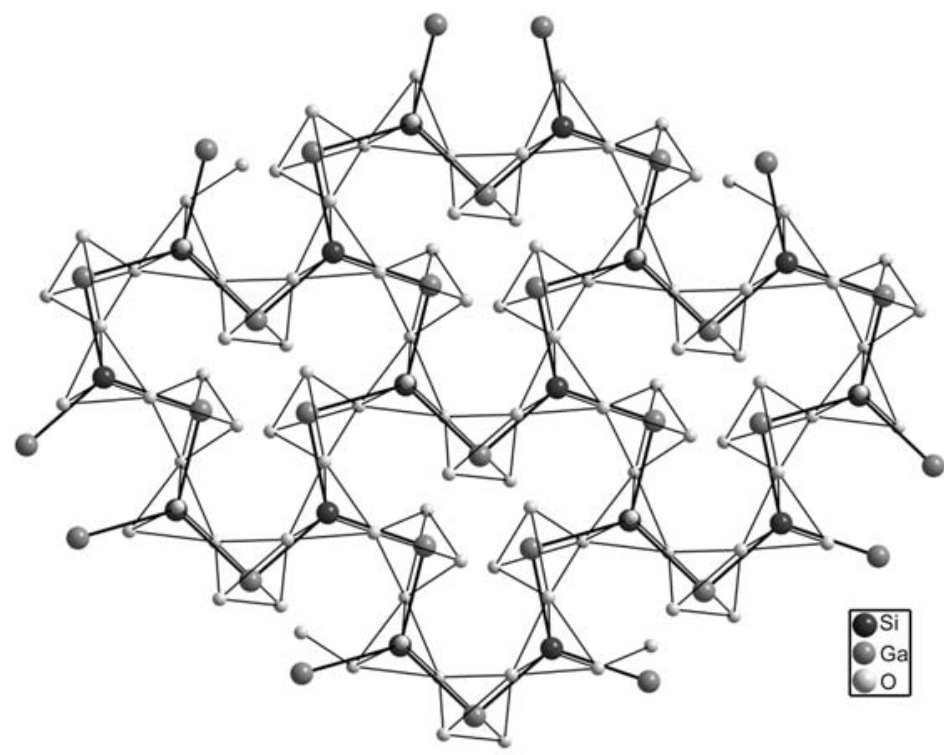

a

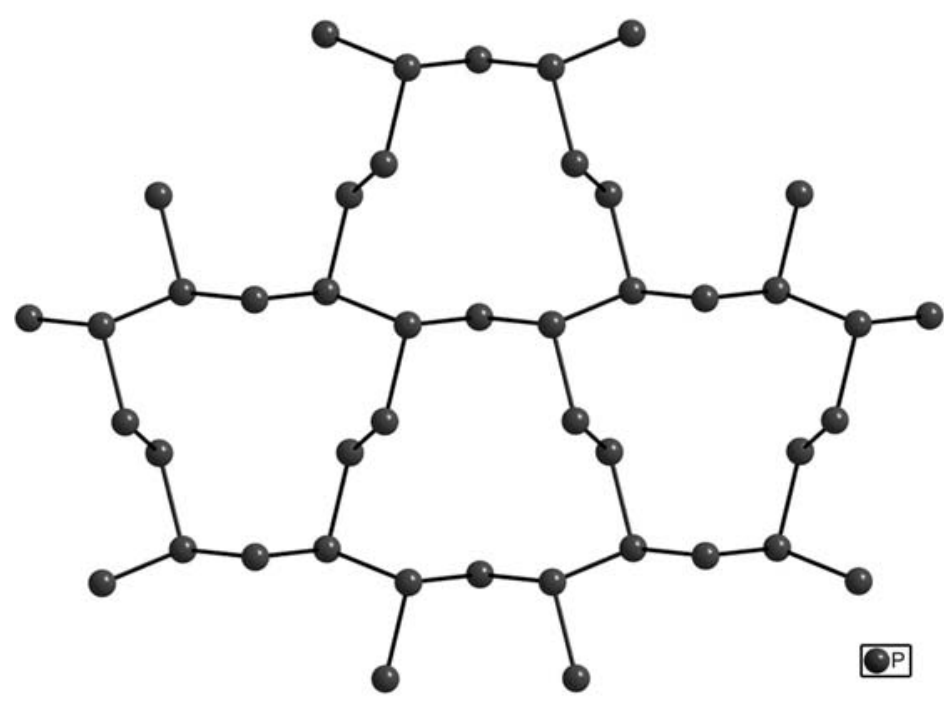

b

Fig. 15 (a) The structure of the $\left[\mathrm{Ga}_{4} \mathrm{SiO}_{14}\right]^{12-}$ layer in $\mathrm{La}_{3} \mathrm{Ga}^{[6]}\left[\mathrm{Ga}_{3}^{[4][1 ; 3\rfloor} \mathrm{Ga}^{[4][1 ; 2\rfloor} \mathrm{Si}^{[4][1 ; 3\rfloor}\right.$ $\mathrm{O}_{14}$ ]. The $\mathrm{Ga}-\mathrm{Si}$ subarray forms a net of $\Psi-\mathrm{P}_{2} \mathrm{~S}_{3}$ (or more accurately $\Psi$-PAsSe ${ }_{3}$ ) pseudo stoichiometry in which the $\Psi$-P atoms are three-connected and the $\Psi$-S atoms are twoconnected. $\mathrm{O}$ atoms are located near to the bonding and lone pair electron positions. This planar layer is strongly related to the corrugated layer formed by the $\mathrm{P}$ atoms in $\mathrm{CeP}_{5}$ which is represented in (b) 
For example, $\mathrm{Na}_{2} \mathrm{ZnSi}_{3} \mathrm{O}_{8}$ [81] can be considered as a single-layer silicate $\mathrm{Na}_{4} \mathrm{Zn}_{2}\left\{1_{\infty}^{2}\right\}\left[\mathrm{Si}_{6} \mathrm{O}_{16}\right]$ if only the $\mathrm{Si}$ skeleton is taken into account. However, the compound can also be seen as a tectosilicate $\mathrm{Na}_{4}\left\{\begin{array}{l}3 \\ \infty\end{array}\right\}\left[\mathrm{Zn}_{2} \mathrm{Si}_{6} \mathrm{O}_{16}\right]$ if the tetrahedrally coordinated $\mathrm{Zn}$ atoms are included in the $\mathrm{T}$ atom framework. In this case, the four $\mathrm{Na}$ atoms per formula unit would convert the two $\mathrm{Zn}$ atoms into $\Psi$-Si. This dual role of $\mathrm{T}$ atoms other than $\mathrm{Si}$ and $\mathrm{Al}$, can occur in other compounds as well. For example, $\mathrm{K}_{2} \mathrm{ZnSi}_{2} \mathrm{O}_{6}$ can either be classified as a chain silicate $\mathrm{K}_{4} \mathrm{Zn}_{2}\left\{{ }_{\infty}^{1}\right\}\left[\mathrm{Si}_{4} \mathrm{O}_{12}\right]$ with unbranched vierer single chains or as a tectosilicate $\mathrm{K}_{2}\left\{\begin{array}{c}3 \\ \infty\end{array}\right\}\left[\mathrm{ZnSi}_{2} \mathrm{O}_{6}\right]$ [82]. In Tables 6-7, corresponding examples have been indicated with *.

\subsection{2}

\section{Double-Layer Silicates}

A small number of compounds have been found to contain silicate anions which can be regarded as a product of the condensation of two single layers. Compounds presenting this kind of framework are also collected in Table 6.

An example of these compounds is provided by the mineral dmisteinbergite, $\mathrm{Ca}\left[\mathrm{Al}_{2} \mathrm{Si}_{2} \mathrm{O}_{8}\right]$ [83] which has previously been called hexacelsian. Its T-atom subarray is a double layer. Each of the two single layers contains only six-membered planar rings, corresponding to the single layers of carbon atoms in graphite. Each T atom of one single layer is "linked" to a T atom

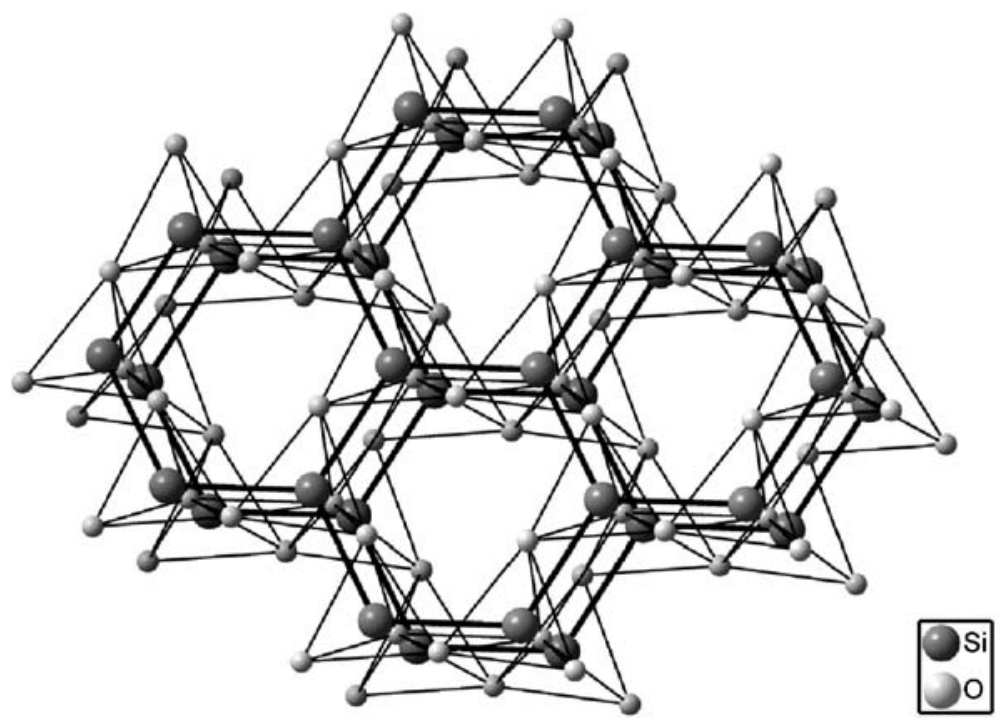

Fig. 16 The double layer formed by the alumosilicate anion in dmisteinbergite, $\mathrm{Ca}\left[\mathrm{Al}_{2} \mathrm{Si}_{2} \mathrm{O}_{8}\right]$. The $\mathrm{Ca}$ atoms convert the $\mathrm{Al}$ atoms into $\Psi$-Si giving rise to a net in which all the $\mathrm{Al}$ and $\mathrm{Si}$ atoms are four-connected 
of the other, as seen in Fig. 16. This skeleton can be explained as a consequence of the electron transfer from calcium to aluminium which is converted into $\Psi-\mathrm{Si}$, thus forming a four-connected net. It is worth mentioning that this skeleton is almost identical to that of the Zintl phases $\mathrm{CaAl}_{2} \mathrm{Si}_{2}$ [84] and $\mathrm{CaAl}_{2} \mathrm{Ge}_{2}$ [85] and that, as reported previously [86], the structure of dmisteinbergite can be derived from that of the Zintl phase by inserting one $\mathrm{O}$ atom between each pair $\mathrm{Al}-\mathrm{Si}$. It is also interesting to point out that these minerals are high temperature phases. At room temperature the structure of feldspar is obtained. This can be interpreted in the light of the equivalence between oxidation and pressure [63]. Thus, oxidation could stabilise a high pressure polymorph of the Zintl phase which would correspond to the cation array of feldspar. When heated, the pressure can be released and the ambient pressure polymorph of the Zintl phase is recovered in dmisteinbergite.

\section{6}

\section{Tectosilicates}

\section{6 .1}

\section{Subdivision of Tetrahedron Frameworks According to Connectivity}

All silicates in which $\left[\mathrm{TO}_{4}\right]$ tetrahedra form 3D tetrahedron frameworks by sharing oxygen atoms are called tectosilicates. The vast majority of tectosilicates contain only four-connected tetrahedra so that each framework oxygen atom is linked to two $\mathrm{T}$ atoms and is, therefore, two-connected. As a consequence, the ratio between $\mathrm{T}$ atoms and framework $\mathrm{O}$ (or more generally $\mathrm{X}$ ) atoms in the unit cell $\mathrm{uc}$ is $\mathrm{z}=\sum_{\mathrm{uc}} n(\mathrm{O}) / \sum_{\mathrm{uc}} n(\mathrm{~T})=2$. For such tectosilicates the term fully linked tectosilicates has been suggested [87, p 50].

There is a relatively small number of tectosilicates which contain $\left[\mathrm{TO}_{4}\right]$ tetrahedra that are linked to less than four others, i.e. which contain, exclusively or in addition to 3-connected $\mathrm{Q}^{3}$ units, also $\mathrm{Q}^{4}$ units and, very rarely, also $\mathrm{Q}^{2}$ and $\mathrm{Q}^{1}$ tetrahedra. These silicates necessarily contain non-bridging framework $\mathrm{O}$ atoms and their atomic ratio $z$ is higher than 2. For them the term underlinked tectosilicates has been proposed [87, p 50f]. They are often, but less accurately, called interrupted framework silicates.

\subsection{2}

\section{Fully Linked Tectosilicates}

In fully linked tectosilicates, the cation ratio $n(A): n(\mathrm{~T})$ is relatively low. The valence electrons of their $\mathbf{A}$ atoms serve to compensate the negative valence of the tetrahedron framework that results from partial replacement of tetrahedrally coordinated $\mathrm{Si}^{4+}$ atoms by $\mathrm{T}$ atoms of lower valence, such as $\mathrm{Al}^{3+}$ and $\mathrm{Zn}^{2+}$. This is the case in all examples given in the main part of Table 7 . 
Table 7

Tectosilicates

Tectosilicates with fully-linked tetrahedron frameworks $\left\{\begin{array}{l}3 \\ \infty\end{array}\right\}$ Pseudo-Si

Mineral name Formula

Ref.

\begin{tabular}{lll}
\hline & Stuffed quartz-type silicates & \\
Virgilite & $\mathrm{A}\left[\mathrm{AlSi}_{2} \mathrm{O}_{6}\right]$ with $\mathrm{A}=\mathrm{H}, \underline{\mathrm{Li}}$ & {$[358 \mathrm{a}-\mathrm{b}]$} \\
$(\beta$-Eucryptite $)$ & $\mathrm{Li}\left[\mathrm{AlSiO}_{4}\right]$ & {$[359]$} \\
& $\mathrm{Mg}\left[\mathrm{Al}_{2} \mathrm{Si}_{3} \mathrm{O}_{10}\right]$ & {$[360]$} \\
& Stuffed cristobalite-type and cristobalite related silicates \\
Liberite & $\mathrm{Li}_{2}\left[\mathrm{BeSiO}_{4}\right]^{*}$ & {$[361]$} \\
(Carnegieite) & $\mathrm{Na}\left[\mathrm{AlSiO}_{4}\right]$ & {$[362]$} \\
& $\mathrm{Li}\left[\mathrm{BSiO}_{4}\right]^{*}$ & {$[363]$} \\
Chkalovite & $\mathrm{Na}_{2}\left[\mathrm{TSiO}_{4}\right]^{*}$ with $\mathrm{T}=\underline{\mathrm{Be}, \mathrm{Mg}}$ & {$[364 \mathrm{a}-\mathrm{c}]$} \\
& $\mathrm{Na}_{2}\left[\mathrm{ZnSi}_{2} \mathrm{O}_{6}\right]^{*}$ & {$[365]$} \\
& $\mathrm{Ba}\left[\mathrm{BeSiO}_{4}\right]^{*}$ & {$[366]$}
\end{tabular}

Stuffed tridymite-type and tridymite related silicates

Nepheline, trinepheline, $\mathrm{A}\left[\mathrm{AlSiO}_{4}\right]$ with $\mathrm{A}=\underline{\mathrm{Na}}, \underline{\mathrm{K}}$

[367a-e] kalsilite, megakalsilite, kaliophilite Yoshiokaite

(Ca), $\left[(\mathrm{AlSi})_{2} \mathrm{O}_{4}\right]$

Stuffed keatite-type silicates

$\mathrm{A}\left[\mathrm{AlSi}_{2} \mathrm{O}_{6}\right]$ with $\mathbf{A}=\mathrm{Li}, \mathrm{Na}, \mathrm{K}$

Stuffed $\mathrm{SrAl}_{2}$-type silicates

$\mathrm{Li}_{2}\left[\mathrm{TSiO}_{4}\right]^{*}$ with $\mathrm{T}=\mathrm{Co}, \mathrm{Zn}$

$\mathrm{K}_{2}\left[\mathrm{ZnSi}_{3} \mathrm{O}_{8}\right]^{*}$

$\mathrm{Rb}\left[\mathrm{AlSiO}_{4}\right]$

\section{Stuffed zeosils}

Zeolites, e.g. natrolite, chabazite, faujasite, mordenite

$\mathrm{A}_{m}\left[(\mathbf{T}, \mathrm{Si})_{n} \mathrm{O}_{2 n}\right]$ with $\mathbf{T}=\mathrm{Be}, \mathrm{Mg}, \mathrm{Zn}, \mathrm{B}, \mathrm{Al},[373 \mathrm{a}-\mathrm{b}]$ $\mathrm{Ga}, \mathrm{Fe}, \mathrm{Co}, \mathrm{Cr}, \mathrm{Ge}, \mathrm{P}$

Feldspar-type silicates

Feldspars, e.g. albite, $\mathrm{A}\left[(\mathrm{T}, \mathrm{Si})_{4} \mathrm{O}_{8}\right]^{*}$ with $\mathrm{T}=\mathrm{B}, \mathrm{Al}, \mathrm{Ga}, \mathrm{Fe}, \mathrm{Ge}, \mathrm{P}[374 \mathrm{a}-\mathrm{h}]$ orthoclase, microcline, anorthite, celsian, danburite, Reedmergnerite

$\begin{array}{lll} & \text { Other silicates with fully-linked }\left[\mathrm{TO}_{2}\right] \text { frameworks } & \\ & \mathrm{Li}_{4}\left[\mathrm{~B}_{4} \mathrm{Si}_{8} \mathrm{O}_{24}\right]^{*} & {[375]} \\ & \beta-\mathrm{Na}_{2}\left[\mathrm{BeSiO}_{4}\right]^{*} & {[376]} \\ & \mathrm{K}_{2}\left[\mathrm{ZnSi}_{2} \mathrm{O}_{6}\right]^{*} & {[377]} \\ & \left(\mathrm{Na}, \mathrm{K}_{2}\left[\mathrm{CuSi}_{4} \mathrm{O}_{10}\right]^{*}\right. & {[378]} \\ \text { Litidionite } & \mathrm{Cs}\left[\mathrm{AlSi}_{5} \mathrm{O}_{12}\right] & {[379]} \\ \text { Cordierite } & \mathrm{A}_{2}\left[\mathrm{Al}_{4} \mathrm{Si}_{5} \mathrm{O}_{18}\right] \text { with } \mathrm{A}=\mathrm{Mg}, \mathrm{Co}, \mathrm{Mn}, \mathrm{Fe} & {[380 \mathrm{a}-\mathrm{e}]} \\ \begin{array}{l}\text { Cuprorivaite, wesselite, } \\ \text { effenbergerite }\end{array} & \mathrm{A}_{2}\left[\mathrm{Cu}_{2} \mathrm{Si}_{8} \mathrm{O}_{20}\right]^{*} \text { with } \mathrm{A}=\underline{\mathrm{Ca}}, \underline{\mathrm{Sr}}, \underline{\mathrm{Ba}} & {[381]} \\ \text { Beryl } & \mathrm{Mg}_{2}\left[\mathrm{Be}_{3} \mathrm{Si}_{6} \mathrm{O}_{18}\right]\left(\mathrm{H}_{2} \mathrm{O}\right)_{x}^{*} & \end{array}$


Table 7 (continued)

\begin{tabular}{lllllll} 
Mineral name & Formula & $l$ & $m$ & $n$ & Ref. \\
\hline & Tectosilicates with underlinked tetrahedron frameworks & \\
\multirow{4}{*}{$\begin{array}{l}\left\{\begin{array}{l}3 \\
\infty\end{array}\right\} \text { Pseudo- } \mathrm{Si}_{k} \mathrm{P}_{l} \mathrm{~S}_{m} \mathrm{Cl}_{n} \\
\text { Wenkite }\end{array}$} & $\mathrm{H}_{2} \mathrm{Ca}_{3} \mathrm{Ba}_{4}\left[\left(\mathrm{Al}_{8} \mathrm{Si}_{12}\right) \mathrm{O}_{41}\right]\left(\mathrm{SO}_{4}\right)_{3}\left(\mathrm{H}_{2} \mathrm{O}\right)$ & 18 & 2 & 0 & 0 & {$[383]$} \\
Chiavennite & $\left.\mathrm{H}_{2} \mathrm{CaMn}^{\left[\mathrm{Be}_{2}, 3\right]} \mathrm{Si}_{5}^{[1,4]} \mathrm{O}_{15}\right]\left(\mathrm{H}_{2} \mathrm{O}\right)_{2}^{*}$ & 5 & 2 & 0 & 0 & {$[384]$} \\
& $\mathrm{Na}_{4}\left[\mathrm{Si}_{6} \mathrm{O}_{14}\right]$ & 2 & 4 & 0 & 0 & {$[385]$} \\
& $\mathrm{K}_{2} \mathrm{Ce}\left[\mathrm{Si}_{6} \mathrm{O}_{15}\right]$ & 0 & 6 & 0 & 0 & {$[386]$} \\
& $\mathrm{Rb}_{6}\left[\mathrm{Si}_{10} \mathrm{O}_{23}\right]$ & 4 & 6 & 0 & 0 & {$[387]$} \\
& $\mathrm{Ce}_{4}\left[\mathrm{Si}_{4} \mathrm{O}_{4} \mathrm{~N}_{6}\right] \mathrm{O}$ & 0 & 4 & 0 & 0 & {$[388]$} \\
\hline
\end{tabular}

\subsubsection{1}

\section{Relationship between the Frameworks of Fully Linked Tectosilicates and Silica}

The most simple oxides matching the relation $\mathbf{z}=\sum_{\mathrm{uc}} n(\mathrm{O}) / \sum_{\mathrm{uc}} n(\mathrm{~T})=2$ are the binary silica polymorphs with the exception of those HP polymorphs in which silicon has coordination numbers higher than four, i.e. stishovite, distorted stishovite and $\mathrm{CaF}_{2}$-type silica. In all known $\mathrm{SiO}_{2}$ phases with tetrahedrally coordinated $\mathrm{Si}$ atoms, each $\mathrm{O}$ atom is shared between two $\left[\mathrm{SiO}_{4}\right]$ tetrahedra. This leads necessarily to the formation of a 3D framework. As mentioned in the introduction and as reported previously [8], these 3D tetrahedron frameworks and their corresponding 3D Si-atom subarrays are fourconnected and maintain the structure of elemental phases of either silicon or other elements of Group 14 of the PSE.

Some quaternary tectosilicates are considered as stuffed derivatives of quartz, cristobalite, tridymite, keatite and chabazite, and their Si-substructures (with the exception of chabazite) reproduce the structure of phases of either elements of Group 14 of the PSE, Si and Ge, or compounds which are intimately related to them. Thus, the diamond-like structure of the $\mathrm{Si}$ subarray is found in cristobalite, the wurtzite-like structure of Si appears in tridymite, keatite reproduces the structure of $\gamma$-Ge. In quartz, the Si atoms adopt the structure of the related compound $\mathrm{CrSi}_{2}[23]$ and also the cinnabarlike structure of the high pressure II-VI compounds such as ZnTe [24].

Other groups of silicates adopt very complicated frameworks which maintain the fourfold connectivity. For them, no structural relationship has been found with similar Zintl phases. However, all of them fulfil the Zintl-Klemm concept when applied to the element which accompanies the Si atom in the tetrahedral framework.

The remaining compounds present interesting structural similarities and some of them will be discussed below. 


\subsubsection{2}

\section{The $\mathrm{SrAl}_{2}$-type Skeleton}

These compounds, such as $\mathrm{Rb}\left[\mathrm{AlSiO}_{4}\right]$ [88] (see Table 7), form 3D tetrahedron frameworks consisting of four- and eight-membered rings which give rise to a fourfold connectivity. The structure is represented in Fig. 17. Although no phase of the Group 14 elements is known to have this structure, it is identical to that adopted by the $\mathrm{Al}(\Psi-\mathrm{Si})$ atoms in the Zintl phase $\mathrm{SrAl}_{2}$ [89]. The $\mathrm{O}$ atoms are located near to the centres of all the $\mathrm{Al}-\mathrm{Si}$ bonds producing the tetrahedral coordination of the $\mathrm{Al}(\mathrm{Si})$ atoms. Once more, the cation subarray, in an oxide, behaves as if it were a Zintl polyanion.

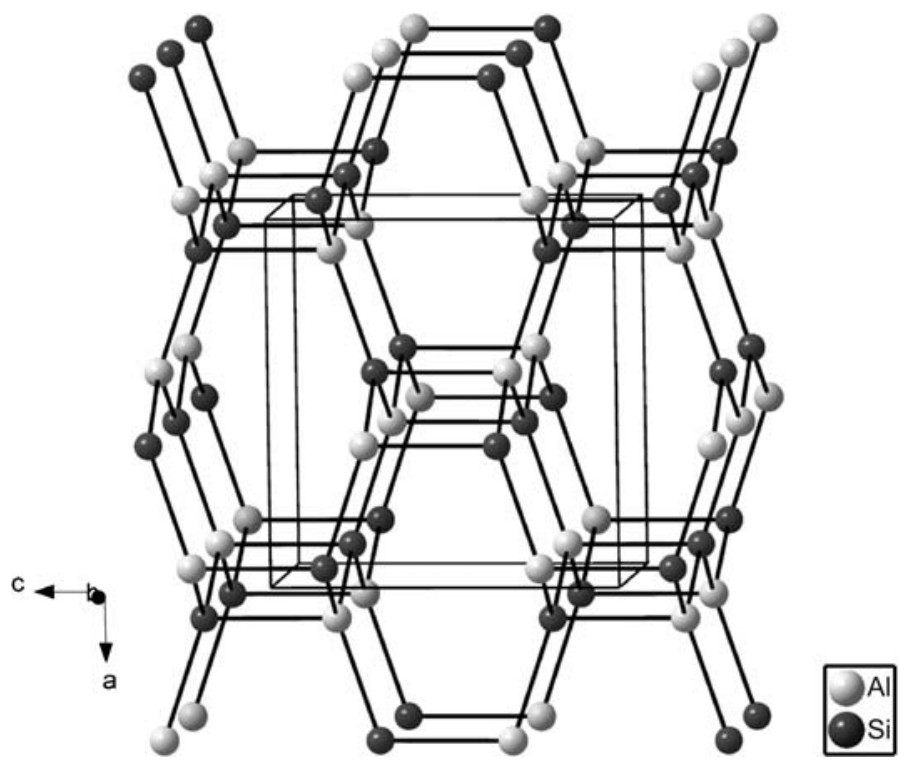

Fig. 17 The structure of the $\mathrm{T}$-atom subframework of $\mathrm{Rb}\left[\mathrm{AlSiO}_{4}\right]$. The AlSi subarray is similar to that existing in the Zintl phase $\mathrm{SrAl}_{2}$ where the $\mathrm{Al}$ atoms have been converted into $\Psi$-Si, and all atoms are four-connected

\subsubsection{3}

\section{The Feldspar Structure}

Compounds belonging to this group are also listed in Table 7. All of them are borosilicates and alumosilicates in which the $\mathrm{B}, \mathrm{Al}$ and $\mathrm{Si}$ atoms form a 3D framework of four-connected tetrahedra. Consequently, the $\mathrm{T}$ atom skeleton is also four-connected (Fig. 18). It is remarkable that the structures of feldspars and that of coesite $\left(\mathrm{SiO}_{2}\right.$ polymorph) are similar. This seems to be reasonable because, in compounds such as slawsonite $\mathrm{Sr}\left[\mathrm{Al}_{2} \mathrm{Si}_{2} \mathrm{O}_{8}\right]$ [90], and reedmergnerite $\mathrm{Na}\left[\mathrm{BSi}_{3} \mathrm{O}_{8}\right]$ [91], the electropositive cations convert the $\mathrm{Al}$ 

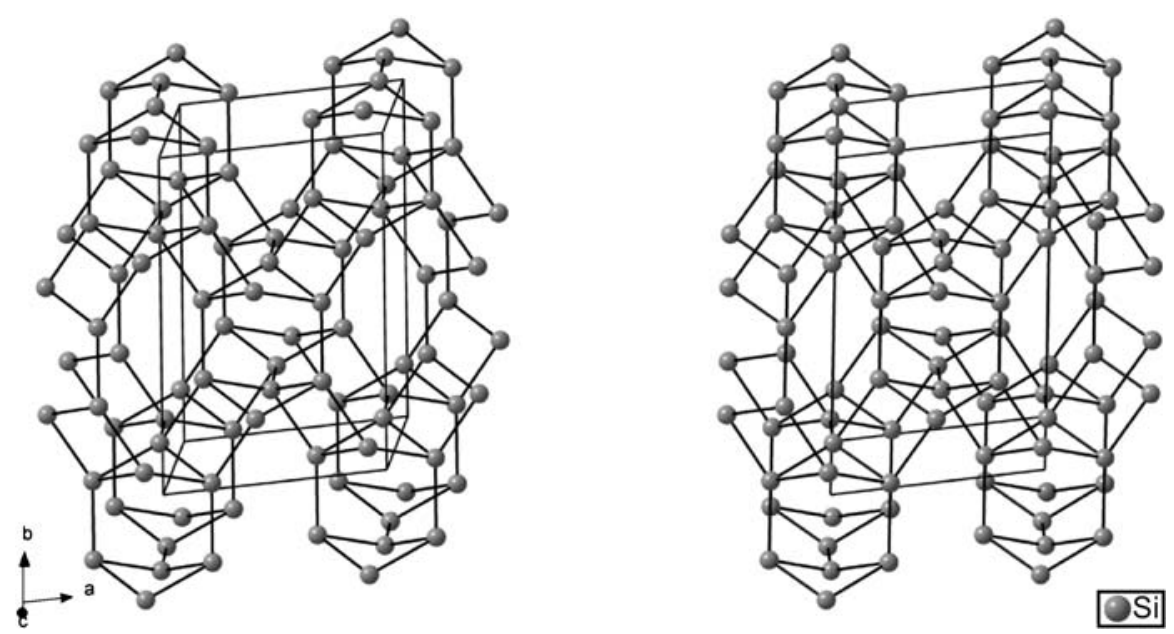

Fig. 18 Stereopair showing the 3D T-atom subarray of the feldspar $\mathrm{Rb}\left[\mathrm{AlSi}_{3} \mathrm{O}_{8}\right]$. As seen all the $\mathrm{Al}$ and $\mathrm{Si}$ atoms are four-connected

and $\mathrm{B}$ atoms into $\Psi$-Si/C atoms giving rise to a framework of stoichiometry $\mathrm{TO}_{2}$.

\subsubsection{4}

\section{Paracelsian and Variscite}

Variscite [92] is the mineral name of one of the two phases of $\mathrm{AlPO}_{4}$. $2 \mathrm{H}_{2} \mathrm{O}$, the other being metavariscite [93]. Its AlP subarray forms a 3D fourconnected framework in which each $\mathrm{Al}$ atom is connected to four $\mathrm{P}$ atoms and vice versa. A projection of the structure is represented in Fig. 19a. This array shows strong similarities with the structure of paracelsian $\mathrm{Ba}\left[\mathrm{Al}_{2} \mathrm{Si}_{2} \mathrm{O}_{8}\right]$ [94] which is also adopted by the isostructural compounds $\mathrm{Ca}\left[\mathrm{B}_{2} \mathrm{Si}_{2} \mathrm{O}_{8}\right]$ (danburite) [95], $\mathrm{K}\left[\mathrm{BSi}_{3} \mathrm{O}_{8}\right]$ [96] and $\mathrm{Na}_{2}\left[\mathrm{ZnSi}_{3} \mathrm{O}_{8}\right]$ [97]. The AlSi subarray of the paracelsian is represented in Fig. 19b. It is formed by four-, six-, and eightmembered rings. Again, there are strong similarities between the $\mathrm{T}$ atom framework of these silicates and the arrays of III-V oxidic compounds such as $\mathrm{AlPO}_{4} \cdot 2 \mathrm{H}_{2} \mathrm{O}$. In the light of the Zintl-Klemm concept this means that a $\Psi$-Si array is formed when the electropositive atoms donate their valence electrons to the more electronegative $\mathrm{B}, \mathrm{Zn}$ and $\mathrm{Al}$ atoms. It should be remarked that this framework has never been observed, neither in any of the phases of silica nor in the HP phases of silicon, and that only fragments of this net exist in the form of small organic molecules [8]. Here the question arises again whether this skeleton is only stable for oxidic III-V compounds such as variscite or, on the contrary, can also be stable in phases of the elements of Group 14 of the PSE. 


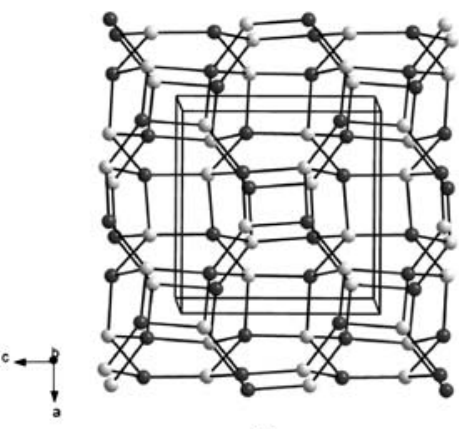

a

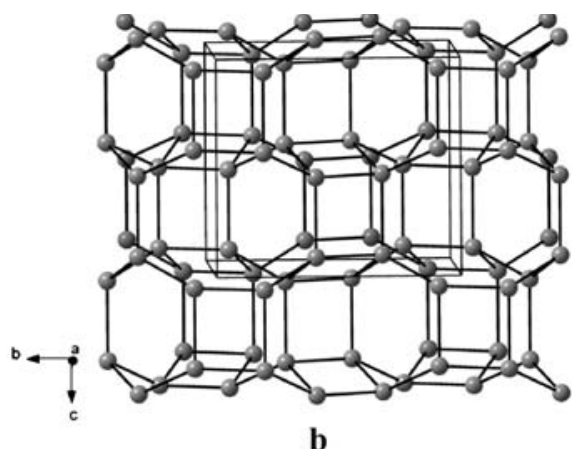

Fig. 19 a The AlP network in variscite $\mathrm{AlPO}_{4} \cdot 2 \mathrm{H}_{2} \mathrm{O}$. This III-V net adopts a fourfold connectivity characteristic of the IV-IV compounds. b The AlSi network in paracelsian $\mathrm{Ba}\left[\mathrm{Al}_{2} \mathrm{Si}_{2} \mathrm{O}_{8}\right]$. The $\mathrm{Ba}$ atoms convert the $\mathrm{Al}$ atoms into $\Psi$-Si which together with the $\mathrm{Si}$ atoms form a four-connected net similar to that of variscite (a)

It is worth mentioning that the structure of paracelsian has been related to that of metavariscite [98]. However, an inspection of three projections of the paracelsian structure reveals that two of them are strongly related with the other two projections of variscite and that, in fact, paracelsian must be considered as an intermediate structure between the two phases of $\mathrm{AlPO}_{4} \cdot 2 \mathrm{H}_{2} \mathrm{O}$.

\subsection{3}

\section{Underlinked Tectosilicates}

If the cation ratio $n(\mathrm{~A}): n(\mathrm{~T})$ increases, an excess of valence electrons becomes available that can be transferred to $\mathrm{T}$ atoms to produce pseudo-atoms in agreement with the Zintl-Klemm concept. Examples of such underlinked tectosilicates are listed in the last part of Table 7. For instance, in the zeolite chiavennite, $\mathrm{H}_{2} \mathrm{CaMn}(\mathrm{II})\left[\mathrm{Be}_{2} \mathrm{Si}_{5} \mathrm{O}_{15}\right]\left(\mathrm{H}_{2} \mathrm{O}\right)_{2}$ [99], the non-tetrahedral cations can transfer six valence electrons per formula unit to the $\mathrm{Be}$ atoms, transforming them into $\Psi$-P atoms. As a result, the two $\left[\mathrm{BeO}_{4}\right]$ tetrahedra are 3-connected whereas the five $\left[\mathrm{SiO}_{4}\right]$ tetrahedra are 4-connected.

Another two examples of underlinked silicates are the compounds $\mathrm{Ce}_{4}\left[\mathrm{Si}_{4} \mathrm{O}_{4} \mathrm{~N}_{6}\right] \mathrm{O}$ and $\mathrm{K}_{2} \mathrm{Ce}\left[\mathrm{Si}_{6} \mathrm{O}_{15}\right]$ in which the $\mathrm{Si}$ atoms present a threefold connectivity.

In $\mathrm{Ce}_{4}\left[\mathrm{Si}_{4} \mathrm{O}_{4} \mathrm{~N}_{6}\right] \mathrm{O}$ [100], the four trivalent $\mathrm{Ce}$ atoms per formula unit provide 12 valence electrons. Two of them are transferred directly to an $\mathrm{O}$ atom not bonded to silicon, $6 \mathrm{e}^{-}$must be considered as extra electrons to be transferred to the six $\mathrm{N}$ atoms if they are compared with the $\mathrm{O}$ atoms. The remaining $4 \mathrm{e}^{-}$serve to transform the four $\mathrm{Si}$ atoms into $\Psi$-P which, as said above, are three-connected. 
The same can be said of $\mathrm{K}_{2} \mathrm{Ce}\left[\mathrm{Si}_{6} \mathrm{O}_{15}\right]$ [101]; the six valence electrons per formula unit provided by $\mathrm{K}$ and tetravalent Ce atoms serve to convert the six $\mathrm{Si}$ atoms into $\Psi$-P, with the corresponding threefold connectivity.

It should be remembered that in the Zintl phase $\mathrm{SrSi}_{2}$, the $\Psi$-P atoms also form a 3D array with three-connected atoms, although the skeleton is not similar to those of the compounds discussed here.

\section{6}

\section{Si Atoms in Octahedral Coordination}

A general survey of hexa-coordinated silicon compounds has been reported by Finger and Hazen [102].

Previously we have discussed that in some silicates, as a result of the amphoteric behaviour of the $\mathrm{Si}$ atoms, part or all of the silicon atoms are hexa-coordinated whereas the others have the normal tetrahedral coordination. We must refer here again to the compounds $\mathrm{Na}_{2} \mathrm{Si}^{[6]}\{\boldsymbol{t}\}\left[\mathrm{Si}_{2}^{[4]} O_{7}\right]$ [39], $\mathrm{K}_{2} \mathrm{Si}^{[6]}\{\boldsymbol{u} \boldsymbol{B}, 1 \boldsymbol{r}\}\left[\mathrm{Si}_{3}^{[4]} \mathrm{O}_{9}\right]$ [52], $\mathrm{Na}_{8} \mathrm{Si}^{[6]}\{\boldsymbol{u} \boldsymbol{B}, 1 \boldsymbol{r}\}\left[\mathrm{Si}_{6}^{[4]} \mathrm{O}_{18}\right]$ [53] and $\mathrm{Na}_{6} \mathrm{Si}_{3}^{[6]}$ $\{u B, 1 r\}\left[\mathrm{Si}_{9}^{[4]} \mathrm{O}_{27}\right]$ [54] discussed previously. The first compound was discussed in Sect. 5.2.1. It should be remembered that this HP phase contains one hexa-coordinated $\mathrm{Si}$ atom and two tetra-coordinated $\mathrm{Si}$ atoms per formula unit which form a disilicate anion $\left[\mathrm{Si}_{2} \mathrm{O}_{7}\right]^{6-}$. The other three silicates were discussed in Sect. 5.3.1 devoted to ring silicates. The first one contains one hexa-coordinated $\mathrm{Si}$ atom, the other three four-coordinated $\mathrm{Si}$ atoms forming a three-membered ring $\left[\mathrm{Si}_{3} \mathrm{O}_{9}\right]^{6-}$. The next phase presents one hexacoordinated $\mathrm{Si}$ atom per formula unit, whereas the remaining six $\mathrm{Si}$ atoms form a six-membered ring $\left[\mathrm{Si}_{6} \mathrm{O}_{18}\right]^{12-}$. In the last one, also a HP phase, there are three donor, hexa-coordinated $\mathrm{Si}$ atoms which coexist with a ninemembered planar ring.

Thus, a donor behaviour of $\mathrm{Si}$ leads to an octahedral coordination whereas the acceptor character produces the tetrahedral coordination. This trend is clearly seen in the various polymorphs of silicon oxophosphate $\mathrm{SiP}_{2} \mathrm{O}_{7}$ [103-106] which contain all their silicon atoms in octahedral coordination, even though they are not high-pressure phases. It has been pointed out [107] that the tendency of silicon to form $\left[\mathrm{SiO}_{6}\right]$ octahedra instead of $\left[\mathrm{SiO}_{4}\right]$ tetrahedra is due to the stronger electronegativity of the central oxoanion atom (in this case phosphorus). Thus, $\mathrm{SiP}_{2} \mathrm{O}_{7}$ is a clear example of how the donor character of silicon leads to octahedral coordination of silicon. On the other hand, $\mathrm{SiP}_{2} \mathrm{O}_{7}$ can also be described by application of the Zintl-Klemm concept. Since $\mathrm{P}$ is more electronegative than $\mathrm{Si}$, each of the two $\mathrm{P}$ atoms per formula unit subtracts two valence electrons from $\mathrm{Si}$ in order to become a $\Psi$-halogen atom. Therefore, $\mathrm{Si}^{[6]}\left[\mathrm{P}_{2}^{[4]} \mathrm{O}_{7}\right]$ can be compared with the disilicates such as thortveitite, the $\mathrm{Sc}_{2}^{[6]}\left[\mathrm{Si}_{2}^{[4]} \mathrm{O}_{7}\right]$ phase which is stable at ambient 
$\mathrm{P} / \mathrm{T}$ conditions [108]. In this silicate, $\mathrm{Si}$ is more electronegative than $\mathrm{Sc}$ and, therefore, subtracts the valence electrons from Sc to form $\Psi$-halogen atoms.

The compound $\mathrm{Ce}_{16} \mathrm{Si}^{[6]}\left[\mathrm{Si}_{14}^{[4]} \mathrm{O}_{6} \mathrm{~N}_{32}\right]$ is of special interest. It is an oxonitridosilicate with silicon partly coordinated by nitrogen [109]. It has been considered by the authors as strongly related to the perovskite type $\mathrm{A}^{[12]} \mathbf{G}^{[6]} \mathbf{X}_{3}$. Its unit cell can be considered as a cubic $4 \times 4 \times 4$ superstructure of the ideal cubic perovskite in which, of the 64 octahedral positions per unit cell, four are occupied by $\mathrm{Si}^{[6]}, 56$ by $\mathrm{Si}^{[4]}$ and four $\mathbf{G}$ positions are unoccupied. In contrast, the 64 cuboctahedral $\mathrm{A}^{[12]}$ positions are fully occupied by $\mathrm{Ce}^{3+}$ cations. The valence of these cations is compensated by $24 \mathrm{O}^{2-}$ and $128 \mathrm{~N}^{3-}$ anions, so that $40 \mathrm{X}$ positions of the perovskite superstructure are vacant. Therefore, the compound could also be formulated as $\mathrm{Ce}_{16}\left[\mathrm{Si}^{[6]} \mathrm{Si}_{14}^{[4]} \square\left(\mathrm{O}_{6} \mathrm{~N}_{32} \square_{10}\right)\right]$, with $Z=4$. The subarray of tetrahedrally coordinated $\mathrm{Si}$ atoms is represented in Fig. 20. This interpretation has been supported by the argument that the stability of the structure is primarily determined by the cations and that these maintain, in the oxonitridosilicate, the topology which is typical for the perovskite structures. This conclusion has led Liebau [107] to consider several other structures which had been previously described as ring silicates to be defect perovskites.

However, this description provokes an important question, i.e. why are the cationic vacancies where they are and not in other sites? Applying the Zintl-Klemm concept to this compound, the $64 \mathrm{Ce}$ atoms and the 4 hexacoordinated Si atoms per unit cell, which act as donors, provide a total of 208 electrons. If we assume that $128 \mathrm{e}^{-}$are captured by the $128 \mathrm{~N}$ atoms, these are converted into $\Psi-\mathrm{O}$ (this last argument should not be considered as a real
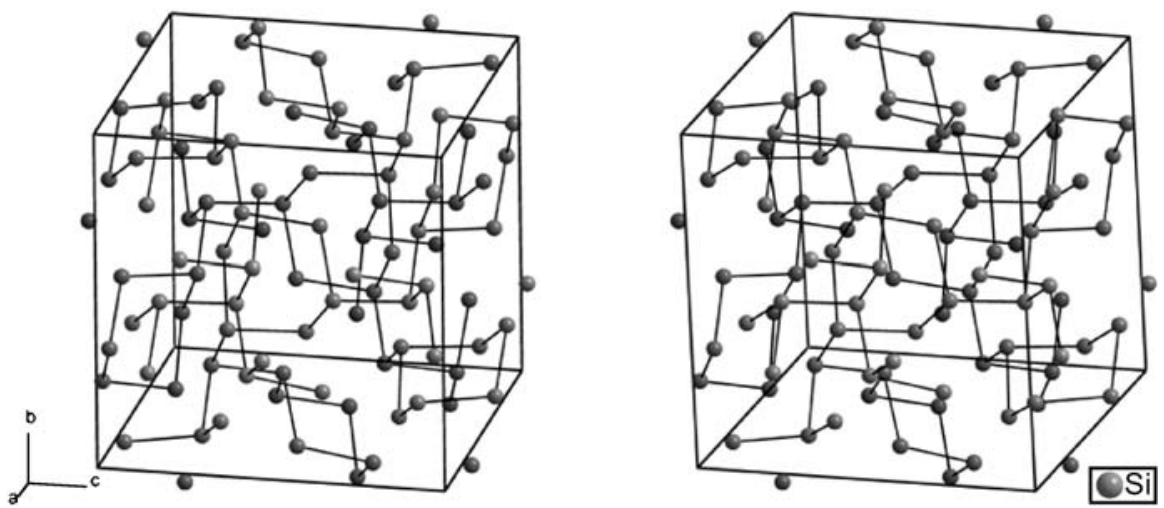

Fig. 20 Stereopair showing the framework of tetrahedrally coordinated $\mathrm{Si}$ atoms in $\mathrm{Ce}_{16}\left[\mathrm{Si}_{15} \mathrm{O}_{6} \mathrm{~N}_{32}\right]$. The framework is formed by three- and two-connected $\mathrm{Si}$ atoms as if they were $\Psi$-P and $\Psi$-S, in the ratio $4: 3$. The octahedrally coordinated Si atoms and the Ce atoms (all of them donors) have been omitted 
process, it only means that each $\mathrm{N}$ atom needs one electron more than an $\mathrm{O}$ atom to satisfy its valence requirements). There remain 80 electrons per unit cell which can be transferred to the tetrahedral Si framework which is composed of 56 silicon atoms. The $24 \mathrm{Si}(1)$ atoms, at the site $24 d$, can accept $2 \mathrm{e}^{-}$ each (a total of $48 \mathrm{e}^{-}$) and are converted into $\Psi$-S atoms, with a twofold connectivity. The $24 \mathrm{Si}(2)$ and $8 \mathrm{Si}(3)$ atoms, at the sites $24 d$ and $8 c$ respectively, can accept $1 \mathrm{e}^{-}$each and are converted into $\Psi$-P atoms (a total of $32 \mathrm{e}^{-}$). The resulting $\mathrm{Si}^{[4]}$ framework can be represented by the pseudo- $\mathrm{P}_{4} \mathrm{~S}_{3}$ structure type, corresponding to three- and two-connected $\mathrm{T}$ atoms in the ratio $4: 3$. The $\mathrm{O}$ and $\mathrm{N}$ atoms are located near to the midpoints of the $\mathrm{Si}-\mathrm{Si}$ contacts giving rise to the tetrahedral coordination observed in the $\mathrm{T}$ atom skeleton.

However, there exist some compounds which, at high pressures, produce structures with only hexa-coordinated silicon but in which silicon has an acceptor character. It can be shown that these structures can also be explained in the light of the Zintl-Klemm concept.

The first compound to be discussed is $\mathrm{MgSiO}_{3}$ which, under ambient $\mathrm{P} / \mathrm{T}$ conditions, has a chain with the pyroxene structure in which all $\mathrm{Si}$ atoms have tetrahedral coordination and are two-connected: $\operatorname{Mg}_{2}^{[6]}\left\{\begin{array}{l}1 \\ \infty\end{array}\right\}\left[\mathrm{Si}_{2}{ }^{[4]\lceil 1 ; 2\rfloor}\right.$ $\mathrm{O}_{6}$ ] [110]. At high pressures and high temperatures, it transforms into an orthorhombically distorted perovskite [111] in which the Si atoms become octahedrally coordinated by $\mathrm{O}$ and the $\mathrm{Mg}$ atoms adopt an eightfold coordination: $\mathrm{Mg}^{[8]}\left\{\begin{array}{l}3 \\ \infty\end{array}\right\}\left[\mathrm{Si}^{[6][1 ; 6]} \mathrm{O}_{3}\right]$. This phase transition can be interpreted as an increase of the coordination number for both, $\mathrm{Mg}$ and $\mathrm{Si}$, as a consequence of the application of pressure. However, in the light of the Zintl-Klemm concept, it can instead be interpreted as if the one-dimensional Si atom skeleton of the pyroxene chain, which is equivalent to the structure of fibrous sulfur, would have been transformed into the three-dimensional Si atom skeleton which is equivalent to the $\mathrm{Te}$ atom skeleton in $\mathrm{TeO}_{3}$ [112]. We have seen that, when the 8-N rule is applied, a $\Psi$-S atom forms two bonds. However, in the heavier elements of Group 16, such as Te, each atom can also use its six $5 s^{2} 5 p^{4}$ valence electrons to form six bonds (simple cubic structure). Thus, a $\Psi$-S atom can use its six $3 s^{2} 3 p^{4}$ valence electrons to form six two-centre, two-electron bonds with its six neighbours. The $\mathrm{O}$ atoms are then docked close to the six bonding pairs giving rise to the octahedral coordination. This interpretation of the perovskite structure has previously been reported [8] and theoretical calculations have also shown [113] that the defect perovskite structure is a stable one for the isoelectronic $\mathrm{SO}_{3}$.

A corresponding phase transition at $\mathrm{HP}$ from $\mathrm{Ca}\left[\mathrm{Si}^{[4][1 ; 2]} \mathrm{O}_{3}\right]$ to perovskitetype $\mathrm{Ca}\left[\mathrm{Si}^{[6][1 ; 6]} \mathrm{O}_{3}\right]$ has been observed for $\mathrm{CaSiO}_{3}$ [102]. It is quite possible that it can also take place in $\mathrm{SrSiO}_{3}$ and $\mathrm{BaSiO}_{3}$. In the case of $\mathrm{BaSiO}_{3}$, the possibility of such a transition is supported by the fact that its $\mathrm{BaSi}$ subarray is of the CrB-type which, under pressure, undergoes the CrB-type $\rightarrow$ CsCl-type transition as has been reported for $\mathrm{KClO}_{3}$ [114]. 


\section{7}

\section{Concluding Remarks}

As was stated for the aluminates [8], the structures just described and the above discussion clearly indicate that the Zintl-Klemm concept is maintained in the oxides and that the atoms forming the Zintl polyanions, behave structurally as real Zintl polyanions in spite of being embedded in an oxygen matrix. Following the term proposed by Parthé \& Chabot [5], the Si atoms occupying tetrahedrally coordinated positions of the anion substructure can be considered as "cations ex-officio". It seems clear that the application of the Zintl-Klemm concept can serve to rationalise and understand the skeletons of hundreds of silicates which had remained for many years at a descriptive level. The great number of similarities between the topology of the T-atom subarrays and the structures of Zintl polyanions clearly indicate that these similarities are not casual but they are new examples of how cations, in oxides, recognise themselves as previously shown for many other compounds [63].

One of the most interesting aspects of the above discussion is the rationalisation of the coordination number $\mathrm{CN}$ adopted by silicon in different compounds. It is well known that silicon normally appears as tetrahedrally coordinated and that the octahedral coordination should be regarded as an abnormal feature which has traditionally been attributed to the application of pressure. In this context the quartz $\rightarrow$ stishovite transition has been explained and, in the same manner, the presence of hexa-coordinated silicon in the HP phases $\mathrm{Na}_{2} \mathrm{Si}^{[6]}\left[\mathrm{Si}_{2}^{[4]} \mathrm{O}_{7}\right.$ ] [39], $\mathrm{K}_{2} \mathrm{Si}^{5[6]}\left[\mathrm{Si}_{3}^{[4]} \mathrm{O}_{9}\right.$ ] [52], $\mathrm{Na}_{8} \mathrm{Si}^{[6]}\left[\mathrm{Si}_{6}^{[4]} \mathrm{O}_{18}\right.$ ] [53] and in $\mathrm{Na}_{6} \mathrm{Si}_{3}^{[6]}\left[\mathrm{Si}_{9}^{[4]} \mathrm{O}_{27}\right]$ [54] could be understood. We see, however, that in the latter compounds both types of coordination polyhedra coexist and that this can be explained by an amphoteric behaviour of the $\mathrm{Si}$ atoms, i.e. $\mathrm{Si}^{[6]}$ acts as a donor whereas $\mathrm{Si}^{[4]}$ behaves as an acceptor producing the $\left[\mathrm{Si}_{2} \mathrm{O}_{7}\right]^{6-},\left[\mathrm{Si}_{3} \mathrm{O}_{9}\right]^{6-},\left[\mathrm{Si}_{6} \mathrm{O}_{18}\right]^{12-}$ and $\left[\mathrm{Si}_{9} \mathrm{O}_{27}\right]^{18-}$ anions respectively. It is true that the application of pressure can favour the donor character and hence an increase in the $\mathrm{CN}$, but pressure should not be the only reason for it. In part, because pressure should produce the octahedral coordination for all the $\mathrm{Si}$ atoms, but also because the same structural features are present in $\mathrm{Ce}_{16} \mathrm{Si}^{[6]}\left[\mathrm{Si}_{14}^{[4]} \mathrm{O}_{6} \mathrm{~N}_{32}\right]$ [109] which is not a high-pressure phase. We are aware that the coexistence of both types of coordination polyhedra in the same compound is a feature difficult to explain. It represents an important problem whose ultimate reasons need to be rationalised. We do not know at present which factors (electronic and geometric) determine this behaviour. However, the results just discussed seem to indicate that the formation of appropriate tetrahedral networks must be an important factor for the structure stabilisation. This can require, in some cases, the donor behaviour of some Si atoms. We have also seen how the difference in electronegativity is 
an important factor which allows silicon to adopt an octahedral coordination in the presence of more electronegative tetrahedral atoms, as is the case in $\mathrm{Si}^{[6]}\left[\mathrm{P}_{2}^{[4]} \mathrm{O}_{7}\right][103-107]$.

It should be remembered that the existence, and in some instances the coexistence, of both types of coordination polyhedra (octahedra and tetrahedra) was also present in aluminates [8]. There, it was discussed that the coordination number of the $\mathrm{Al}$ atoms was not a function of the size of the cation but rather a consequence of the atoms accompanying it in the structure and of the behaviour of the Al itself. The same can be said of silicon and silicates. The different $\mathrm{CN}$ values are difficult to explain if we are thinking of the existence of $\mathrm{Si}^{4+}$ cations. However, a rational insight is obtained if we think of the existence (or pre-existence) of the Zintl polyanions we have described. Again, the oxonitridosilicate $\mathrm{Ce}_{16} \mathrm{Si}^{[6]}\left[\mathrm{Si}_{14}^{[4]} \mathrm{O}_{6} \mathrm{~N}_{32}\right.$ ] [109] provides a good example of this assertion. We have mentioned above that this compound was described as a perovskite variant with an ordered distribution of vacancies. Because similar defect perovskite structures can be recognised in many other silicates, it has been claimed that this arrangement can be considered as an expression of the strong stability of this structure type [107] and that this could be the reason for the appearance, against all expectations, of $\left[\mathrm{SiN}_{6}\right]$ octahedra. These considerations being valid, we believe that the principles applied here provide another explanation which accounts for the location of vacancies in the Si subnet. Thus, defects are not situated at random or located in arbitrary positions but they are situated in such a way that they produce the connectivity characteristic of a Zintl polyanion, in this specific case with pseudo-stoichiometry $\mathrm{P}_{4} \mathrm{~S}_{3}$, which is that obtained if the valence electrons of both, cerium and octahedral silicon are transferred to the remaining $\mathrm{Si}$ atoms. It could be argued that the octahedral silicon atoms act as true cations whereas tetrahedral silicon acts as a cation ex-officio.

Other aspects of the structures discussed here, such as the location of the $\mathrm{O}$ atoms should also be considered. As we have seen, the $\mathrm{O}$ atoms are placed near both, the midpoints of the hypothetical $\mathrm{Si}-\mathrm{Si}$ bonds and the lone pairs, producing a lack of linearity in the $\mathrm{Si}-\mathrm{O}-\mathrm{Si}$ bonds. The fact that the $\mathrm{O}$ atoms are normally situated close to (but not exactly at) the midpoint of a $\mathrm{Si}-\mathrm{Si}$ bond produces the same effect as the rotation of the tetrahedra. This rotation was postulated [115] to derive the real structure of $\beta$-cristobalite $(I \overline{4} 2 d)$ [116] from the non-existing ideal C9 structure. However, it is observed that, rather than tilting rigid $\left[\mathrm{SiO}_{4}\right]$ tetrahedra, the $\mathrm{O}$ atoms are located $0.5-0.6 \AA$ off the centres of the elongated $\mathrm{Si}-\mathrm{Si}$ bonds, thus producing $\mathrm{Si}-\mathrm{O}-\mathrm{Si}$ angles of around $140^{\circ}$. In fact, the Si array is topologically the same and has almost the same dimensions in both the tetragonal and the ideal C9 structures. It is true that the rotation of the tetrahedra has been experimentally observed as a continuous process when pressure is applied to the cristobalite-like compound $\mathrm{BPO}_{4}$ [117], however, this rotation cannot be claimed to account for the for- 
mation of real cristobalite from a non-existing ideal C9 structure. When the structure is seen as derived from Si itself, it is unnecessary to postulate the existence of repulsive forces as responsible for the opening of the $\mathrm{Si}-\mathrm{O}-\mathrm{Si}$ angles, as concluded elsewhere [115].

Another related question is: why do $\mathrm{O}$ atoms respond in the same way to both the more delocalised bonding pairs and the more localised lone pairs. An answer to this question would be that the bonding pairs could also be forming non-nuclear maxima (NNM) between the two cations (bonded Si atoms). Regarding the possible existence of these NNM, it has been reported that their formation seems to be related to the application of pressure [118]. However, what can be concluded is that an $\mathrm{O}^{2-}$ anion seems to play the same role as a bonding electron pair.

Most of the compounds we have discussed can be better understood in the light of the Zintl-Klemm concept and Pearson's generalised octet rule. The connectivity between $\mathrm{Si}$ atoms is explained in all cases. In many of them, the $\mathrm{Si}$ atoms form skeletons identical to the corresponding Zintl polyanions. If no such Zintl polyanions are known, they should be energetically so favourable that their discovery is to be expected. It seems clear that these two old ideas, the Zintl-Klemm concept and Pearson's generalised octet rule, are neither exhausted nor out of date but can still serve to simplify and clarify structures which have not been explained otherwise.

The search is open to apply these principles to other families of compounds such as borates, gallates, germanates, phosphates and arsenates, among others. Probably, their application will allow us to put all these more or less unconnected structures on a common and universal basis. Another problem which remains unsolved is the physical meaning of the "cation recognition" that seems to exist in the oxides $[8,63]$. We believe that this feature represents a challenge for theoretical chemistry which needs to be explained in the future.

Acknowledgements Thanks are due to Prof. M. Mingos (Oxford) for valuable suggestions. The present work was supported by DGI of MEC (Spain) under project MAT200405867-C03-02. D.S.-P., wishes to express his thanks to the Residencia de Estudiantes and Ayuntamiento de Madrid for their support.

\section{References}

1. Lima-de-Faria J (2001, 2003, 2004) Structural Classification of Minerals, Vols. 1-3. Kluwer, Dordrecht

2. Marumo F, Isobe M, Akimoto S (1977) Acta Cryst B33:713

3. Liebau F (1985) Structural Chemistry of Silicates. Springer, Berlin Heidelberg New York

4. Parthé E, Engel N (1986) Acta Cryst B42:538

5. Parthé E, Chabot B (1990) Acta Cryst B46:7 
6. Zintl E (1939) Angew Chem 52:1

7. Klemm W (1958) Proc Chem Soc London 329

8. Santamaría-Pérez D, Vegas A (2003) Acta Cryst B59:305

9. Pearson WB (1964) Acta Cryst 17:1

10. Smith DK, Roberts AC, Bayliss P, Liebau F (1998) Am Mineral 83:126

11. Lima-de-Faria J, Hellner E, Liebau F, Makovicky E, Parthé E (1990) Acta Cryst A46:1

12. Yang H, Evans BW (1996) Am Mineral 81:1117

13. Kabalov YuK, Sokolova EV, Pautov LA, Schneider J (1998) Crystallogr Repts 43:584

14. Hoffmann R (1988) Solids and Surfaces. A Chemist's View of Bonding in Extended Structures. VCH, Weinheim New York, p 3

15. Schäfer H (1985) Ann Rev Mater Sci 15:1

16. Coppens P, Yang YW, Blessing RH, Cooper WF, Larsen FK (1977) J Am Chem Soc 99:760

17. Häussermann U, Wengert S, Hofmann P, Savin A, Jepsen O, Nesper R (1994) Angew Chem Int Ed Engl 33:2069

18. Nesper R (2003) Structural and Electronic Systematics in Zintl Phases of the Tetrels. In: Jutzi P, Schubert U (eds) Silicon Chemistry. Wiley-VCH, Weinheim, p 171

19. Miller GJ (1996) Structure and Bonding at the Zintl Border. In: Kauzlarich SM (ed) Chemistry, Structure and Bonding of Zintl Phases and Ions, Chap 1. VCH, Weinheim

20. Eisenmann B, Cordier G (1996) Structural Patterns of Homo- and Heteronuclear Anions in Zintl Phases and Related Intermetallic Compounds and Concepts for Their Interpretation. In: Kauzlarich SM (ed) Chemistry, Structure and Bonding of Zintl Phases and Ions, Chap 2. VCH, Weinheim

21. Corbett JD (1996) Zintl Phases of the Early p-block Elements. In: Kauzlarich SM (ed) Chemistry, Structure and Bonding of Zintl Phases and Ions, Chap 3. VCH, Weinheim

22. Iota V, Yoo CS, Cynn H (1999) Science 283:1510

23. Mattheiss LF (1992) Phys Rev B 45:3252

24. McMahon MI, Nelmes RJ, Wright MG, Allan DR (1994) AIP Conference Proceedings 309:633

25. Wells AF (1984) Structural Inorganic Chemistry, $5^{\text {th }}$ ed. Clarendon Press, Oxford

26. Kasper JS, Richards SM (1964) Acta Cryst 17:752

27. Kirfel A, Krane H-G, Blacha P, Schwarz K, Lippmann T (2001) Acta Cryst A57:663

28. Barnett JD, Bean VE, Hall HT (1966) J Appl Phys 37:875

29. Gallmeier J, Schäfer H, Weiss A (1969) Z Naturforsch B24:665

30. O’Keeffe M, Hyde BG (1985) Structure and Bonding 61:77

31. Addison WE (1965) Structural Principles in Inorganic Compounds. Longmans, London

32. Arbib EH, Elouadi B, Chaminade JP, Darriet J (1996) J Solid State Chem 127:350

33. Stachel D, Svoboda I, Fuess H (1995) Acta Cryst C51:1049

34. Pertlik F (1978) Mh Chemie 109:277

35. Savin A, Nesper R, Wengert S, Fässler TF (1997) Angew Chem Int Ed Engl 36:1808

36. Eisenmann B, Limartha H, Schäfer H, Graf HA (1980) Z Naturforsch B35:1518

37. Deller K, Eisenmann B (1976) Z Anorg Allg Chem 425:104

38. Simon A, Borrmann H (1988) Angew Chem Int Ed Engl 27:1339

39. Fleet ME, Henderson GS (1995) Phys Chem Miner 22:383

40. Simonov MA, Egorov-Tismenko YuK, Belov NV (1978) Sov Phys Dokl 23:6

41. Jansen M, Keller H-L (1979) Angew Chem Int Ed Engl 18:464

42. von Schnering H-G, Wittmann M, Sommer D (1984) Z Anorg Allg Chem 510:61

43. Hanawa M, Kobayashi T, Imoto H (2000) Z Anorg Allg Chem 626:216

44. Eisenmann B, Jordan H, Schäfer H (1983) Z Naturforsch B38:404 
45. Poojary DM, Borade RB, Clearfield A (1993) Inorg Chim Acta 208:23

46. Hawthorne FC (1987) N Jb Miner Mh 1987:16

47. Lenain P, Picquenard E, Lesne JL, Corset J (1986) J Mol Struct 142:355

48. Steudel R, Mäusle H-J, Rosenbauer D, Möckel H, Freyholdt T (1981) Angew Chem Int Ed Engl 20:394

49. Steidel J, Pickardt J, Steudel R (1978) Z Naturforsch B33:1554

50. Kräuter T, Neumüller B (1995) Z Anorg Allg Chem 621:597

51. Steidel J, Steudel R, Kutoglu A (1981) Z Anorg Allg Chem 476:171

52. Swanson DK, Prewitt CT (1983) Am Mineral 68:581

53. Fleet ME (1998) Am Mineral 83:618

54. Fleet ME (1996) Am Mineral 81:1105

55. Haile SM, Maier J, Wuensch BJ, Laudise RA (1995) Acta Cryst B51:673

56. Chivers T, Proctor J (1979) Can J Chem 57:1286; Roesky HW, Rao MNS, Nakajima T, Sheldrick PS (1979) Chem Ber 112:3531

57. Nagase S (1989) Angew Chem Int Ed Engl 28:329

58. Baudler M, Scholz G, Tebbe K-F, Fehér M (1989) Angew Chem Int Ed Engl 28:339

59. Törnroos KW, Calzaferri G, Imhof R (1995) Acta Cryst C51:1732

60. Liu F, Garofalini SH, King-Smith RD, Vanderbilt D (1993) Chem Phys Lett 215:401

61. Currao A, Curda J, Nesper R (1996) Z Anorg Allg Chem 622:85

62. Grosse HP, Tillmanns E (1974) Cryst Struct Comm 3:603

63. Vegas A, Jansen M (2002) Acta Cryst B58:38

64. Gobechiya ER, Pekov IV, Pushcharovskii DYu, Ferraris G, Gula A, Zubkova NV, Chukanov NV (2003) Crystallogr Rpts 48:750

65. Zürcher F, Nesper R (1998) Angew Chem Int Ed Engl 37:3314

66. Yang H-X, Konzett J (2000) Am Mineral 85:259

67. Iglesias JE, Zuniga FJ, Nowacki W (1977) Z Kristallogr 146:43; Palazzi M, Jaulmes S (1977) Acta Cryst B33:908

68. Eisenmann B, Schäfer H (1979) Z Anorg Allg Chem 456:87

69. Rehr A, Guerra F, Parkin S, Hope H, Kauzlarich SM (1995) Inorg Chem 34:6218

70. Schiferl D, Barrett CS (1969) J Appl Cryst 2:30

71. Smith RI, Howie RA, West AR, Aragón-Piña A, Villafuerte-Castrejón ME (1990) Acta Cryst C46:363

72. de Jong BHWS, Supèr HTJ, Spek AL, Veldman N, Nachtegaal G, Fischer JC (1998) Acta Cryst B54:568

73. Pant AK, Cruickshank DWJ (1968) Acta Cryst B24:13

74. Pant AK (1968) Acta Cryst B24:1077

75. Bissert G, Hesse K-F (1978) Acta Cryst B34:1322

76. Kahlenberg V, Dörsam G, Wendschuh-Josties M, Fischer RX (1999) J Solid State Chem 146:380

77. Fleet ME, Henderson GS (1995) J Solid State Chem 119:400

78. Rakić S, Kahlenberg V, Weidenthaler C, Zibrowius B (2002) Phys Chem Miner 29:477

79. Belokoneva EL, Stefanovich SYu, Pisarevskii YuV, Mosunov AV (2000) Zh Neorg Khim 45:1786

80. von Schnering HG, Wittmann M, Peters K (1998) Z Kristallogr-NCS 213:460

81. Hesse K-F, Liebau F, Böhm H, Ribbe PH, Phillips MW (1977) Acta Cryst B33:1333

82. Hogrefe AR, Czank M (1995) Acta Cryst C51:1728

83. Takéuchi Y, Donnay G (1959) Acta Cryst 12:465

84. Gladyshevskii EI, Krypyakevich PI, Bodak OI (1967) Ukr Fiz Zh 12:445

85. Kranenberg C, Johrendt D, Mevis A (2002) Solid State Sci 4:261

86. Vegas A, Santamaría-Pérez D (2003) Z Kristallogr 218:466 
87. Liebau F (2003) Micropor Mesopor Mater 58:15

88. Klaska R, Jarchow O (1975) Z Kristallogr 142:225

89. Cordier G, Czech E, Schäfer H (1982) Z Naturforsch B37:1442

90. Tagai T, Hoshi T, Suzuki M, Kato A, Matsubara S (1995) Z Kristallogr 210:741

91. Fleet ME (1992) Am Mineral 77:76

92. Kniep R, Mootz D, Vegas A (1977) Acta Cryst B33:263

93. Kniep R, Mootz D (1973) Acta Cryst B29:2292

94. Chiari G, Gazzoni G, Craig JR, Gibbs GV, Louisnathan SJ (1985) Am Mineral 70:969

95. Sugiyama K, Takeuchi Y (1985) Z Kristallogr 173:293

96. Kimata M (1993) Mineral Mag 57:157

97. Hesse K-F, Liebau F, Böhm H, Ribbe PH, Phillips MW (1977) Acta Cryst B33:1333

98. Kniep R (1986) Angew Chem Int Ed Engl 25:525

99. Tazzoli V, Domeneghetti MC, Mazzi F, Cannillo E (1995) Eur J Miner 7:1339

100. Irran E, Köllisch K, Leoni S, Nesper R, Henry PF, Weller MT, Schnick W (2000) Chemistry: A European Journal 6:2714

101. Karpov OG, Pobedimskaya EA, Belov NV (1977) Sov Phys Cryst 22:215

102. Finger LW, Hazen RM (1991) Acta Cryst B47:561

103. Tillmanns E, Gebert W, Baur WH (1973) J Solid State Chem 7:69

104. Hesse KF (1979) Acta Cryst B35:724

105. Bissert G, Liebau F (1970) Acta Cryst B26:233

106. Poojary DM, Borade RB, Campbell III FL, Clearfield A (1994) J Solid State Chem 112:106

107. Liebau F (1999) Angew Chem Int Ed Engl 38:1733

108. Kimata M, Saito S, Matsui T, Shimizu M, Nishida N (1998) N Jb Miner Mh 1998:361; Foord EE, Birmingham SD, Demartin F, Pilati T, Gramaccioli CM, Lichte F (1993) Can Mineral 31:337

109. Köllisch K, Schnick W (1999) Angew Chem Int Ed Engl 38:357

110. Nestola F, Tribaudino M (2003) Eur J Miner 15:365; Tribaudino M, Nestola F, Cámara F, Domeneghetti MC (2002) Am Mineral 87:648; Yang H-X, Ghose S (1995) Phys Chem Miner 22:300; Wentzcovitch RM, Hugh-Jones DA, Angel RJ, Price GD (1995) Phys Chem Miner 22:453 [110]; Ito E, Matsui Y (1978) Earth Planet Sci Lett 38:443

111. Fiquet G, Dewaele A, Andrault D, Kunz M, Le Bihan T (2000) Geophys Res Lett 27:21

112. Ahmed MAK, Fjellvåg H, Kjekshus A (2000) J Chem Soc Dalton Trans 2000:4542

113. Tamm T, Pyykkö P (2002) Chem Commun 2002:336

114. Pistorius CWFT (1972) J Chem Phys 56:6263

115. O'Keeffe M, Hyde BG (1981) The Role of Nonbonded Forces in Crystals. In: O'Keeffe M, Navrotsky A (eds) Structure and Bonding in Crystals. Wiley, New York, Vol. I, Chapter 10

116. Wright AF, Leadbetter AJ (1975) Phil Mag 31:1391

117. Haines J, Chateau C, Léger JM, Bogicevic C, Hull S, Klug DD, Tse JS (2003) Phys Rev Lett 91:015 503

118. Martín-Pendás A, Blanco MA, Costales A, Mori-Sánchez P, Luaña V (1999) Phys Rev Lett 83:1930

119. Schmahl WW, Swainson IP, Dove MT, Graeme-Barber A (1992) Z Kristallogr 201:125

120. Seifert HJ, Nowotny H, Hauser E (1971) Monatsh Chem 102:1006

121. Schulze GER (1934) Z Phys Chem B24:215

122. Achary SN, Jayakumar OD, Tyagi AK, Kulshresththa SK (2003) J Solid State Chem $176: 37$

123. Kokkoros P (1956) Tschermaks Min Petr Mitt 6:116

124. Spiess M, Gruehn R (1978) Naturwiss 65:594 
125. Többens DM, Stüsser N, Knorr K, Mayer HM, Lampert G (2001) Mater Sci Forum 378:288

126. Rundqvist S (1962) Acta Chem Scand 16:1

127. Staritzky E (1956) Anal Chem 28:915

128. Jamieson JC, Demarest HH jr (1969) J Appl Phys 40:2617

129. Kihara K, Matsumoto T, Imamura M (1986) Z Kristallogr 177:39; Fleming JE, Lynton H (1960) Phys Chem Glasses 1:148; Graetsch HA (2003) Z Kristallogr 218:531; Kihara K (1981) Z Kristallogr 157:93; Graetsch HA (2001) Phys Chem Miner 28:313; Kato K, Nukui A, Jarchow O, Loens J (1998) Z Kristallogr 213:392; Löns J, Hoffmann W (1987) Z Kristallogr 178:141; Konnert JH, Appleman DE (1978) Acta Cryst B34:391

130. Graetsch HA (2001) Acta Cryst C57:665; Graetsch HA (2002) Acta Cryst C58:18; Graetsch HA (2000) Acta Cryst C56:401

131. Ownby PD, Yang X, Liu J (1990) J Mater Res 5:2272

132. Jennings HM, Richman MH (1976) Science 193:1242

133. Tucker MG, Keen DA, Dove MT (2001) Mineral Mag 65:489

134. Glinnemann J, King HE jr, Schulz H, Hahn T, la Placa SJ, Dacol F (1992) Z Kristallogr 198:177

135. Iota V, Yoo CS, Cynn H (1999) Science 283:1510

136. Haines J, Cambon O, Astier R, Fertey P, Chateau C (2004) Z Kristallogr 219:32

137. Muraoka Y, Kihara K (1997) Phys Chem Miner 24:243; Sowa H, Macavei J, Schulz H (1990) Z Kristallogr 192:119

138. Arnold AP (1986) Z Kristallogr 177:139

139. Tanaka K, Nawata K, Inui H, Yamaguchi M, Koiwa M (2001) Mater Res Soc Symp Proc 646:N4.3.1; Mattheiss LF (1992) Phys Rev B45:3252

140. McMahon MI, Nelmes RJ, Wright MG, Allan DR (1994) AIP Conf Proc 309:633

141. Shropshire J, Keat PP, Vaughan PA (1959) Z Kristallogr 112:409

142. Kasper JS, Richards SM (1964) Acta Cryst 17:752

143. Kirfel A, Krane H-G, Blaha P, Schwarz K, Lippmann T (2001) Acta Cryst A57:663

144. Yamanaka T, Kurashima R, Mimaki J (2000) Z Kristallogr 215:424

145. Hill RJ (1982) Mater Res Bull 17:769; Harada H, Sasa Y, Uda M (1981) J Appl Crystallogr 14:141

146. Barnett JD, Bean VE, Hall HT (1966) J Appl Phys 37:875

147. Gies H (1983) Z Kristallogr 164:247; Nakagawa T, Kihara K, Harada K (2001) Am Mineral 86:1506

148. Gallmeier J, Schäfer H, Weiss A (1969) Z Naturforsch B24:665

149. Kniep R, Mootz D (1973) Acta Cryst B29:2292

150. Andersson S, Lundstroem T (1968) Acta Chem Scand 22:3103

151. Smith DK jr, Cline CF (1965) Acta Cryst 18:393

152. Kniep R, Mootz D, Vegas A (1977) Acta Cryst B33:263

153. Kasper JS, Richards SM (1964) Acta Cryst 17:752

154. Jansen M, Moebs M (1984) Inorg Chem 23:4486

155. Jansen M, Strojek S (1997) Z Naturforsch B52:906

156. Lüer B, Jansen M (1991) Z Kristallogr 197:247

157. Jansen M, Lüer B (1986) Z Kristallogr 177:149

158. Ballirano P, Maras A (2002) Z Kristallogr NCS 217:177

159. Svenson C (1975) Acta Cryst B31:2016

160. Dehlinger U (1927) Z Kristallogr 66:108

161. Simon A, Borrmann H, Craubner H (1987) Phosph Sulfur and Related Elements 30:507 
162. Arbib EH, Elouadi B, Chaminade JP, Darriet J (1996) J Solid State Chem 127:350

163. Evers J, Oehlinger G, Weiss A (1977) J Solid State Chem 20:173

164. Evers J, Oehlinger G, Weiss A (1980) Z Naturforsch B35:397

165. Brauer G, Mitius A (1942) Z Anorg Allg Chem 249:325

166. Stachel D, Svoboda I, Fuess H (1995) Acta Cryst C51:1049

167. Pertlik F (1978) Monatsh Chem 109:277

168. Schiferl D, Barrett CS (1969) J Appl Cryst 2:30

169. Dick S, Oehlinger G (1998) Z Kristallogr NCS 213:232

170. Jansen M (1978) Z Anorg Allg Chem 441:5; Jansen M (1979) Z Naturforsch B34:10

171. Janzon KH, Schäfer H, Weiss A (1965) Angew Chem Int Ed Engl 4:245

172. Jansen M (1979) Acta Cryst B35:539

173. Amador J, Gutiérrez-Puebla E, Monge MA, Rasines I, Ruiz-Valero C (1988) Inorg Chem 27:1367

174. Kumada N, Kinomura N, Woodward PM, Sleight AW (1995) J Solid State Chem $116: 281$

175. Aksel'rud LG, Hanfland M, Schwarz U (2003) Z Kristallogr NCS 218:414

176. Cucka P, Barrett CS (1962) Acta Cryst 15:865; Aksel'rud LG, Hanfland M, Schwarz U (2003) Z Kristallogr NCS 218:415

177. Westrik R, MacGillavry CH (1954) Acta Cryst 7:764

178. Stahl K, Legros JP, Galy J (1992) Z Kristallogr 202:99

179. Žak Z (1980) Z Anorg Allg Chem 460:81

180. Champarnaud-Mesjard JC, Blanchandin S, Thomas P, Mirgorodsky A, MerleMéjean T, Frit B (2000) J Phys Chem Solids 61:1499

181. Crichton WA, Vaughan GBM, Mezouar M (2001) Z Kristallogr 216:417

182. Keller R, Holzapfel WB, Schulz H (1977) Phys Rev B16:4404

183. Adenis C, Langer V, Lindqvist O (1989) Acta Cryst C45:941

184. Pascard R, Pascard-Billy C (1965) Acta Cryst 18:830

185. Lenain P, Picquenard E, Lesne JL, Corset J (1986) J Mol Struct 142:355

186. Mijlhoff FC (1965) Acta Cryst 18:795

187. Steudel R, Mäusle HJ, Rosenbauer D, Möckel H, Freyholdt T (1981) Angew Chem Int Ed Engl 20:394

188. Ahmed MAK, Fjellvåg H, Kjekshus A (2000) J Chem Soc Dalton Trans 2000:4542; Dusek M, Loub J (1988) Powder Diffr 3:175

189. Jamieson JC, McWhan DB (1965) J Chem Phys 43:1149; Takumi M, Masamitsu T, Nagata K (2002) J Phys Cond Matter 14:10 609

190. DeSando RJ, Lange RC (1966) J Inorg Nucl Chem 28:1837

191. Beyer H (1967) Z Kristallogr 124:228

192. Spencer JR, Jessup KL, McGrath MA, Ballester GE, Yelle R (2000) Science 288:1208

193. Ma Z-S, Shi N-C, Mou G-D, Liao L-B (1999) Chin Sci Bull 44:2125

194. Kawamura K, Kawahara A, Iiyama JT (1978) Acta Cryst B34:3181

195. Fleet ME, Henderson GS (1995) Phys Chem Miner 22:383

196. Jansen M (1982) Z Kristallogr 160:127

197. Howie RA, West AR (1977) Acta Cryst B33:381

198. a: Linke C, Jansen M (1996) Z Anorg Allg Chem 622:486; b: Angel RJ, Cressey G, Criddle A (1990) Am Mineral 75:1192; c: Piffard Y, Marchand R, Tournoux M (1975) Rev Chim Miner 12:210

199. Giuseppetti G, Tadini C, Mattioli V (1992) N Jb Miner Mh 1992:13

200. a: Robinson PD, Fang JH (1977) Am Mineral 62:167; b: Rastsvetaeva RK, Chukanov NV (2003) Dokl Akad Nauk SSSR 388:205

201. Saburi S, Kusachi I, Henmi C, Kawahara A, Henmi K, Kawada I (1976) Miner J 8:240 
202. Bellezza M, Merlino S, Perchiazzi N (2004) Eur J Miner 16:957

203. Finger LW, Hazen RM, Zhang J, Ko J, Navrotsky A (1993) Phys Chem Miner 19:361

204. Yamane H, Nagasawa T, Murakami Y, Kamata T, Shindo D, Shimada M, Endo T (1998) Mat Res Bull 33:845

205. Roelofsen-Ahl JN, Peterson RC (1989) Can Mineral 27:703

206. Plaisier JR, Jansen J, de Graaff RAG, Ijdo DJW (1995) J Solid State Chem 115:464

207. Cannillo E, Mazzi F, Rossi G (1988) Am Mineral 73:608

208. Markgraf SA, Halliyal A, Bhalla AS, Newnham RE, Prewitt CT (1985) Ferroelectrics $62: 17$

209. Kaiser JW, Jeitschko PDW (2000) Z Kristallogr NCS 215:313

210. Choisnet J, Nguyen N, Groult D, Raveau B (1976) Mat Res Bull 11:887

211. Libowitzky E, Schultz AJ, Young DM (1998) Z Kristallogr 213:659

212. Daniels P, Wunder B (1996) Eur J Miner 8:1283

213. Mackenzie KJD, Gainsford GJ, Ryan MJ (1996) J Eur Ceram Soc 16:553

214. Patzke GR, Wartchow R, Binnewies M (2000) Z Kristallogr NCS 215:15

215. a: Foord EE, Birmingham SD, Demartin F, Pilati T, Gramaccioli CM, Lichte FE (1993) Can Mineral 31:337; b: Redhammer GJ, Roth G (2003) Acta Cryst C59:i103; c: Christensen AN (1994) Z Kristallogr 209:7; d: Dias HW, Glasser FP, Gunawardane RP, Howie RA (1990) Z Kristallogr 191:117; e: Müller-Bunz H, Schleid T (2002) Z Anorg Allg Chem 628:564; f: Müller-Bunz H, Schleid T (2000) Z Anorg Allg Chem 626:2549; g: Felsche J (1971) Z Kristallogr 133:364; h: Felsche J (1973) Structure and Bonding 13:150; i: Fleet ME, Liu XY (2001) J Solid State Chem 161:166; j: Chi LS, Chen HY, Deng SQ, Zhuang HH, Huang JS (1997) Jiegon Huaxue 16:177; k: Smolin YuI, Shepelev YuF (1971) Zh Strukt Khim 12:462; l: Christensen AN, Jensen AF, Themsen BK, Hazell RG, Hanfland M, Dooryhee E (1997) Acta Chem Scand 51:1178; m: Smolin YuI, Shepelev YuF, Butikova IK (1970) Sov Phys Crystallogr 15:214; n: Felsche J (1973) Structure and Bonding 13:165; o: Smolin YuI, Shepelev YuF (1970) Acta Cryst B26:484; p: Felsche J (1972) Naturwiss 59:35; q: Chi LS, Chen HY, Zhuang HH, Huang JS (1998) Jiegon Huaxue 17:24

216. a: Chen JT, Guo GC, Huang JS, Zhang QE (1996) Acta Cryst C52:2123; b: Sieke C, Schleid T (2000) Z Anorg Allg Chem 626:196

217. a: Tillmanns E, Gebert W, Baur WH (1973) J Solid State Chem 7:69; b: Bissert G, Liebau F (1970) Acta Cryst B26:233; c: Hesse KF (1979) Acta Cryst B35:724; d: Poojary DM, Borade RB, Campbell FLIII, Clearfield A (1994) J Solid State Chem 112:106

218. Anaias D, Kostova M, Almeida Paz FA, Ferreira A, Carlos LD, Klinowski J, Rocha J (2004) J Am Chem Soc 126:10410

219. Wan Ch, Ghose S, Gibbs GV (1977) Am Mineral 62:503

220. a: Schleid T, Müller-Bunz H (1998) Z Anorg Allg Chem 624:1082; b:Müller- Bunz H, Schleid (2000) Z Anorg Allg Chem 626:845

221. a: Hawthorne FC (1984) Tschermaks Min Petr Mitt 33:135; b: Moore PB, Shen J, Araki T (1985) Am Mineral 70:171

222. Burns PC, Hawthorne FC (1993) Can Mineral 31:321

223. Maksimov BA, Mel'nikov OK, Zhdanova TA, Ilyukhin VV, Belov NV (1980) Sov Phys Dokl 25:143

224. Königstein K, Jansen M (1994) Chem Berichte 1994:1213

225. Jansen M, Keller HL (1979) Angew Chem Int Ed Engl 18:464

226. Tamazyan RA, Malinovskii YuA (1985) Sov Phys Dokl 30:907

227. Safronov AN, Nevskii NN, Ilyukhin VV, Belov NV (1983) Sov Phys Dokl 28:304

228. Gramaccioli CM, Liborio G, Pilati T (1981) Acta Cryst B37:1972

229. Hanawa M, Kobayashi T, Imoto H (2000) Z Anorg Allg Chem 626:216 
230. Poojary DM, Borade RB, Clearfield A (1993) Inorg Chim Acta 208:23

231. Smith JV, Pluth JJ, Richardson Jr JW (1987) Z Kristallogr 179:305

232. Mellini M, Merlino S, Pasero M (1984) Phys Chem Miner 10:99

233. Carlson S, Norrestam R, Holtstam D, Spengler R (1997) Z Kristallogr 212:208

234. Armbruster T, Röthlisberger F (1990) Am Mineral 75:963

235. a: Lager GA, Xie QY, Ross FK, Rossman GR, Armbruster T, Rotella FJ, Schultz AJ (1999) Can Mineral 37:763; b: Armbruster T, Gnos E (2000) Schweiz Min Petr Mitt 80:109

236. Kahlenberg V, Hösch A (2002) Z Kristallogr 217:155

237. Mellini M, Merlino S, Pasero M (1986) Am Mineral 71:176

238. a: Felsche J (1972) Naturwiss 59:35; b: Hartenbach I, Lissner F, Schleid T (2003) Z Naturforsch B58:925

239. Heidebrecht K, Jansen M (1991) Z Anorg Allg Chem 597:79

240. Werthmann R, Hoppe R (1981) Rev Chim Minér 18:593; Hoch C, Röhr C (2001) Z Naturforsch B56:423

241. a: Ginderow D, Cesbron F, Sichère MC (1982) Acta Cryst B38:62; b: Bu XH, Gier TE, Stucky GD (1996) Acta Cryst C52:2662

242. a: Yang HX, Prewitt CT (1999) Am Mineral 84:929; b: Nishi F (1997) Acta Cryst C53:534

243. Merlino S, Pasero M, Bellezza M, Pushcharovsky DYu, Gobetchia ER, Zubkova NV, Pekov IV (2004) Can Mineral 42:1037

244. Yamane H, Nagasawa T, Shimada M, Endo T (1997) Acta Cryst C53:1533

245. Finger LW, Hazen RM, Fursenko BA (1995) J Phys Chem 56:1389; Fischer K (1969) Z Kristallogr 129:222; Hawthorne FC (1987) N Jb Miner Mh 1987:16

246. Müller-Bunz H, Schleid T (1999) Z Anorg Allg Chem 625:1377

247. Dent Glasser LS, Howie RA, Xi YZ (1984) Z Kristallogr 168:307

248. a: Golovastikov NI, Kazak VF (1977) Kristallografiya 22:962; b: Jacobsen H, Meyer G, Schipper W, Blasse G (1994) Z Anorg Allg Chem 620:451

249. Groat LA, Hawthorne FC (1987) Miner Petrol 37:89

250. Colin S, Dupre B, Venturini G, Malaman B, Gleitzer C (1993) J Solid State Chem 102:242

251. Machida KI, Adachi GY, Shiokawa J, Shimada M, Koizumi M, Suito K, Onodera A (1982) Inorg Chem 21:1512

252. Sparta KM, Roth G (2004) Acta Cryst B60:491; Finger LW, Hazen RM, Hemley RJ (1989) Am Mineral 74:952

253. Liu G, Greedan JE (1994) J Solid State Chem 108:267

254. Ohsato H, Takéuchi Y, Maki I (1990) Acta Cryst B46:125

255. Kahlenberg V (2004) J Alloys Comp 366:132

256. Fleet ME (1998) Am Mineral 83:618

257. Ghose S, Wan C, Chao GY (1980) Can Mineral 18:503

258. Artioli G, Rinaldi R, Ståhl K, Zanazzi PF (1993) Am Mineral 78:762; Armbruster T, Libowitzky E, Diamond L, Auernhammer M, Bauerhansl P, Hoffmann C, Irran E, Kurka A, Rosenstingl H (1995) Miner Petrol 52:113

259. Pluth JJ, Smith JH (1973) Acta Cryst B29:73

260. Breuer K-H, Eysel W, Müller R (1989) Z Kristallogr 187:15

261. Malinovskii YuA, Pobedimskaya EA, Belov NV (1975) Sov Phys Dokl 20:163

262. Fleet ME (1996) Am Mineral 81:1105

263. Filipenko OS, Atovmyan IO, Ponomarev VI, Alimova LD, Leonova LS, Bakaev VA, Ukshe EA (1988) Sov Phys Crystallogr 33:44

264. Baumgartner O, Völlenkle H (1977) Z Kristallogr 146:261 
265. Yamnova NA, Rastsvetaeva RK, Pushcharovskii DYu, Mernaf T, Mikheeva MG, Khomyakov AP (1992) Sov Phys Crystallogr 37:167

266. Haile SM, Maier J, Wuensch BJ, Laudise RA (1995) Acta Cryst B51:673

267. Sokolova E, Hawthorne FC, Agakhanov AA, Pautov LA (2003) Can Mineral 41:513

268. a: Kabalov YuK, Sokolova EV, Pautov LA, Schneider J (1998) Crystallogr Rpts 43:584; b: Perrault G, Szymański JT (1982) Can Mineral 20:59; c: Uvarova YuA, Sokolova E, Hawthorne FC, Agakhanov AA, Pautov LA (2004) Can Mineral 42:1005

269. a: Hawthorne FC, Kimata M, Čzerný P, Ball N, Rossman G, Grice JD (1991) Am Mineral 76:1836; b: Wohlfart A (1998) Heidelberger Geowiss Abh 1998:92

270. Armbruster T, Oberhänsli R (1988) Am Mineral 73:585

271. Otto HH, Meibohm M (1999) Z Kristallogr 214:558

272. a: Völlenkle H (1981) Z Kristallogr 154:77; b: Liu F, Garofalini SH, King-Smith RD, Vanderbilt D (1993) Chem Phys Lett 215:401; c: Jansen M, Heidebrecht K, Matthes R, Eysel W (1991) Z Anorg Allg Chem 601:5

273. Grosse H-P, Tillmanns E (1974) Cryst Struct Comm 3:603

274. Horiuchi H, Saito A, Tachi T, Nagasawa H (1997) Am Mineral 82:143

275. Sundberg MR, Lehtinen M, Kivekäs R (1987) Am Mineral 72:173

276. Ohashi Y, Finger LW (1978) Am Miner 63:274; Takéuchi Y, Kudoh Y (1977) Z Kristallogr 146:281

277. a: Ohashi Y (1984) Phys Chem Miner 10:217; b: Hesse K-F (1984) Z Kristallogr 168:93

278. Metcalf Johansen J, Gronbaek Hazell R (1976) Acta Cryst B32:2553

279. Rastsvetaeva RK, Pushcharovskii DYu, Konev AA, Evsyunin VG (1997) Crystallogr Rpts 42:770

280. a: Basso R, Lucchetti G, Palenzona A, Zefiro L (1995) N Jb Miner Mh 1995:281; b: Matsubara S, Kato A, Yui S (1982) Miner J 11:15

281. Pertlik F, Zahiri R (1999) Monatsh Chem 130:257

282. Ohashi Y, Finger LW (1981) Am Mineral 66:154

283. Chao GY (1985) Can Mineral 23:11

284. Merlino S, Pasero M, Artioli G, Khomyakov AP (1994) Am Mineral 79:1185

285. Lin Z, Ferreira A, Rocha J (2003) J Solid State Chem 175:258

286. Pertlik F (2000) Joannea-Mineral 1:31

287. Weber H-P (1983) Acta Cryst C39:1

288. Pagnoux C, Verbaere A, Piffard Y, Tournoux M (1991) Acta Cryst C47:2297

289. Boucher ML, Peacor DR (1968) Z Kristallogr 126:98

290. Maksimov BA, Kalinin VP, Merinov BV, Ilyukhin VV, Belov NV (1980) Sov Phys Dokl 25:415

291. Shi N, Ma Z, Li G, Yamnova NA, Pushcharovskii DYu (1998) Acta Cryst B54:109

292. Bennazha J, Boukhari A, Holt EM (2001) Acta Cryst E57:i12

293. a: Yang H, Konzett J (2000) Am Mineral 85:259; b: Gasparik T, Parise JB, Reeder RJ, Young VG, Wilford WS (1999) Am Mineral 84:257; c: Cannillo E, Mazzi F, Fang JH, Robinson PD, Ohya Y (1971) Am Mineral 56:427

294. Basso R, Della Giusta A (1980) Neues Jb Miner Abh 138:333

295. Czank M, Bissert G (1993) Z Kristallogr 204:129

296. Callegari A, Giuseppetti G, Mazzi F, Tadini C (1992) Neues Jb Miner Mh 1992:49

297. Angel RJ, Ross NL, Finger LW, Hazen RM (1990) Acta Cryst C46:2028

298. Fleet ME (1977) Am Mineral 62:990

299. Middlemiss N, Calvo C (1976) Acta Cryst B32:2896

300. Gobechiya ER, Pekov IV, Pushcharovskii DYu, Ferraris G, Gula A, Zubkova NV, Chukanov NV (2003) Crystallogr Rpts 48:750

301. Meagher EP (1976) Am Mineral 61:67 
302. Zöller MH, Tillmanns E, Hentschel G (1992) Z Kristallogr 200:115

303. Dörsam G, Kahlenberg V, Fischer RX (2003) Z Anorg Allg Chem 629:981

304. de Jong BHWS, Supèr HTJ, Frijhoff RM, Spek AL, Nachtegaal G (2000) Z Kristallogr 215:397

305. Yang H, Hazen RM, Finger LW, Prewitt CT, Downs RT (1997) Phys Chem Miner 25:39

306. Merlino S, Bonaccorsi E, Armbruster T (2001) Eur J Miner 13:577; Merlino S, Bonaccorsi E, Armbruster T (2000) Eur J Mineral 12:411

307. Hejny C, Armbruster T (2001) Z Kristallogr 216:396

308. Robinson PD, Fang JH (1970) Am Mineral 55:1541

309. Peacor DR, Buerger MJ (1962) Am Mineral 47:539

310. Wan C, Ghose S (1978) Am Mineral 63:563

311. a: Johnsen O, Nielsen K, Søtofte I (1978) Z Kristallogr 147:297; b: Gunawardane RP, Howie RA, Glasser FP (1982) Acta Cryst B38:1405; c: Ghose S, Wan C (1978) Am Mineral 63:304: d: Bourguiba NF, Dogguy LS (1994) Mat Res Bull 29:427; e: Cradwick ME, Taylor HFW (1972) Acta Cryst B28:3583; f: Merlino S (1969) Science 166:1399

312. Pozas JMM, Rossi G, Tazzoli V (1975) Am Mineral 60:471

313. Villafuerte-Castrejón ME, Dago A, Caldiño U, Pomes R (1995) J Solid State Chem 114:512

314. Bissert G (1980) Acta Cryst B36:259

315. Tateyama H, Shimoda S, Sudo T (1978) Contrib Miner Petr 66:149

316. Veblen DR, Burnham CW (1978) Am Mineral 63:1053

317. Hesse K-F, Liebau F (1980) Z Kristallogr 153:3

318. Rozhdestvenskaya IV, Nikishova LV, Lazebnik KA (1996) Mineral Mag 60:897

319. Kawamura K, Iiyama JT (1981) Bull Minér 104:387

320. a: Liebau F (1964) Z Kristallogr 120:427; b: Malinovskii YuA, Belov NV (1979) Dokl Akad Nauk SSSR 246:99; c: Bull I, Parise JB (2003) Acta Cryst C59:i100

321. Vortmann S, Rius J, Marler B, Gies H (1999) Eur J Mineral 11:125; Garvie LAJ, Devouard B, Groy TL, Cámara F, Buseck PR (1999) Am Mineral 84:1170

322. a: Smith RI, Howie RA, West AR, Aragón-Piña A, Villafuerte-Castrejón ME (1990) Acta Cryst C46:363; b: De Jong BHWS, Supèr HTJ, Spek AL, Veldman N, Nachtegaal G, Fischer JC (1998) Acta Cryst B54:568; c: De Jong BHWS, Supèr HTJ, Spek AL, Veldman N, van Wezel W, van der Mee V (1996) Acta Cryst B52:770

323. Tagai T, Ried H, Joswig W, Korekawa M (1982) Z Kristallogr 160:159

324. Schweinsberg H, Liebau F (1974) Acta Cryst B30:2206

325. Redhammer GJ, Roth G (2002) Am Mineral 87:1464

326. Liang J-J, Hawthorne FC, Swainson IP (1998) Can Mineral 36:1017

327. Perdikatsis B, Burzlaff H (1981) Z Kristallogr 156:177

328. Hesse K-F, Liebau F (1980) Z Kristallogr 153:33

329. a: Neder RB, Burghammer M, Grasl T, Schulz H, Bram A, Fiedler S (1999) Clays Clay Miner 47:487; b: Zheng H, Bailey SW (1994) Clays Clay Miner 42:46; c: Dera P, Prewitt CT, Japel S, Bish DL, Johnston CT (2003) Am Mineral 88:1428

330. Rakić S, Kahlenberg V (2001) Solid State Sci 3:659

331. Miura Y, Kato T, Rucklidge JC, Matsueda H (1981) Am Mineral 66:416; Stahl K (1993) Eur J Mineral 5:845; Rouse RC, Peacor DR, Dunn PJ (1978) Am Mineral 63:196

332. Hesse K-F, Liebau F, Böhm H, Ribbe PH, Phillips MW (1977) Acta Cryst B33:1333

333. Merlino S, Pasero M, Artioli G, Khomyakov AP (1994) Am Mineral 79:1185

334. Cervantes-Lee FJ, Dent Glasser LS, Glasser FP, Howie RA (1982) Acta Cryst B38:2099

335. Gebert W, Medenbach O, Flörke OW (1983) TMPM Tschermaks Miner Petr Mitt $31: 69$ 
336. a: Bensch W, Schur M (1995) Z Kristallogr 210:530; b: Chakoumakos BC, FernandezBaca JA, Boatner LA (1993) J Solid State Chem 103:105; c: Giester G, Rieck B (1994) Mineral Mag 58:663

337. Szymański JT, Owens DR, Roberts AC, Ansell HG, Chao GY (1982) Can Mineral 20:65

338. Il'inets AM, Nevskii NN, Ilyukhin VV, Belov NV (1983) Sov Phys Dokl 28:213

339. Kato T, Takéuchi Y (1983) Can Mineral 21:1

340. Žunić TB, Šćavnićar S, Molin G (1990) Eur J Mineral 2:731

341. Johnsen O, Leonardsen ES, Fälth L, Annehed H (1983) Neues Jb Miner Mh 1983:505

342. Mikenda W, Pertlik F, Povondra P, Ulrych J (1997) Miner Petrol 61:199

343. Belokoneva EL, Stefanovich SYu, Pisarevskii YuV, Mosunov AV (2000) Zh Neorg Khim 45:1786

344. Krüger H, Kahlenberg V (2005) Z Kristallogr Suppl 22:164

345. Karpov OG, Pushcharovskii DYu, Pobedimskaya EA, Belov NV (1976) Sov Phys Dokl 21:240

346. Balko VP, Bakakin VV, Gatilov YuV, Tseitlin MN, Kurbanov KhM (1985) Sov Phys Dokl 30:549

347. Mikheeva MG, Yamnova NA, Rastsvetaeva RK, Pushcharovskii DYu, Sorokina SL (1992) Sov Phys Crystallogr 37:33

348. Lopes-Vieira A, Zussman J (1969) Mineral Mag 37:49

349. Pushcharovskii DYu, Dago AM, Pobedimskaya EA, Belov NV (1981) Sov Phys Dokl 26:552

350. Jacobsen H, Meyer G (1994) Z Kristallogr 209:348

351. a: Takéuchi Y, Donnay G (1959) Acta Cryst 12:465; Chesnokov BV, Lotova EV, Nigmatulina EN, Pavlyuchenko VS, Bushmakin AF (1990) Zapiski Vses Mineral Obshch 119:43 (Am Mineral 77:446); b: Kremenovic A, Norby P, Dimitrijevic R, Dondur V (1997) Solid State Ionics 101:611; Kremenovic A, Colomban P, Piriou B, Massiot D, Florian P (2003) J Phys Chem Solids 64:2253; c: Bolotina NB, Rastsvetaeva RK, Andrianov VI, Kashaev AA (1991) Sov Phys Crystallogr 36:190

352. Andrews SJ, Papiz MZ, McMeeking R, Blake AJ, Lowe BM, Franklin KR, Helliwell JR, Harding MM (1988) Acta Cryst B44:73

353. Hesse K-F, Liebau F, Merlino S (1992) Z Kristallogr 199:25

354. Cannillo E, Rossi G, Ungaretti L (1968) Rend Acc Naz dei Lincei, Classe Sci Mat Fis Nat, ser 8, 45:131

355. Cannillo E, Rossi G, Ungaretti L (1970) Rend Soc Ital Miner Petrol 26:63

356. Kolitsch U, Tillmanns E (2004) Mineral Mag 68:677

357. Chao GY (1972) Am Mineral 57:765

358. a: Paulus H, Fuess H, Müller G, Vogt T (1990) Neues Jb Miner Mh 1990:232; b: Müller G, Paulus H, Stiefel J (1990) Neues Jb Miner Mh 1990:493

359. Pillars WW, Peacor DR (1973) Am Mineral 58:681

360. Schulz H (1971) Z Kristallogr 134:253

361. Chang HC (1966) Acta Geol Sin 46:76

362. Withers RL, Thompson JG (1993) Acta Cryst B49:614

363. Parise JB, Gier TE (1992) Chem Mater 4:1065

364. a: Simonov MA, Egorov-Tismenko YuK, Belov NV (1976) Sov Phys Dokl 20:805; b: Maksimov B, Tamazyan R, Sirota MI, Frostäng S, Grins J, Nygren M (1990) J Solid State Chem 86:64; c: Withers RL, Lobo C, Thompson JG, Schmid S, Stranger R (1997) Acta Cryst B53:203

365. Simonov MA, Belokoneva EL, Belov NV (1980) Sov Phys Crystallogr 25:731

366. Dann SE, Weller MT (1998) Mat Res Bull 33:683

367. a: Hippler B, Böhm H (1989) Z Kristallogr 187:39; b: Kahlenberg V, Böhm H (1998) Am Mineral 83:631; c: Cellai D, Bonazzi P, Carpenter MA (1997) Am Mineral 82:276, 
Kawahara A, Andou Y, Marumo F, Okuno M (1987) Mineral J 13:260, Dollase WA, Freeborn WP (1977) Am Mineral 62:336; d: Bonaccorsi E, Merlino S, Pasero M (1988) Neues Jb Miner Mh 1988:559; e: Khomyakov AP, Nechelyustov GN, Sokolova E, Bonaccorsi E, Merlino S, Pasero M (2002) Can Mineral 40:961

368. Steele IM, Pluth JJ (1990) Am Mineral 75:1186

369. Baumgartner B, Müller G (1990) Eur J Mineral 2:155

370. a: Yamaguchi H, Akatsuka K, Setoguchi M, Takaki Y (1979) Acta Cryst B35:2680, Takaki Y, Yamaguchi H (1980) Acta Cryst B36:234; b: Yamaguchi H, Akatsuka K, Setoguchi M (1979) Acta Cryst B35:2678

371. Dollase WA, Ross II CR (1993) Z Kristallogr 206:25

372. Klaska R, Jarchow O (1975) Z Kristallogr 142:225

373. a: Baerlocher C, Meier WM, Olson DH (2001) Atlas of Zeolite Framework Types, $5^{\text {th }}$ ed. Elsevier, Amsterdam. Available with updates from http://www.iza-structure.org/ databases/; b: Coombs DS, Alberti A, Armbruster T, Artioli G, Colella C, Galli E, Grice JD, Liebau F, Mandarino JA, Minato H, Nickel EH, Passaglia E, Peacor DR, Quartieri S, Rinaldi R, Ross M, Sheppard RA, Tillmanns E, Vezzalini G (1997) Can Mineral 35:1571, dito (1998) Eur J Mineral 10:1037

374. a: Meneghinello E, Alberti A, Cruciani G (1999) Am Mineral 84:1144; b: Tseng H-Y, Heaney PJ, Onstott TC (1995) Phys Chem Miner 22:399; c: Allan DR, Angel RJ (1997) Eur J Mineral 9:263; d: Matsui T, Kimata M (1997) Eur J Mineral 9:333, Ghose S, McMullan RK, Weber H-P (1993) Z Kristallogr 204:215, Angel RJ, Carpenter MA, Finger LW (1990) Am Mineral 75:150; e: Skellern MG, Howie RA, Lachowski EE, Skakle JMS (2003) Acta Cryst C59:i11; f: Sugiyama K, Takéuchi Y (1985) Z Kristallogr 173:293, Berger T, Range K-J (1996) Z Naturforsch B51:172; g: Fleet ME (1992) Am Mineral 77:76; h: Deubener J, Sternitzke M, Müller G (1991) Am Mineral 76:1620, Bu X, Feng P, Gier TE, Stucky GD (1998) Micropor Mesopor Mater 23:323

375. Parise JB, Gier TE (2000) Int J Inorg Mater 2:81

376. Plakhov GF, Belov NV (1979) Sov Phys Cryst 24:674

377. Hogrefe AR, Czank M (1995) Acta Cryst C51:1728

378. Kawamura K, Iiyama JT (1981) Bull Minéral 104:387

379. Araki T (1980) Z Kristallogr 152:207

380. a: Peplinski B, Müller R, Wenzel J, Sojref R, Schultze D (2000) Mater Sci Forum 321:150, Armbruster T (1985) Neues Jb Miner Mh 1985:255; b: Knorr K, Meschke M, Winkler B (1999) Phys Chem Miner 26:521; c: Malcherek T, Domeneghetti MC, Tazzoli V, Ottolini L, McCammon C, Carpenter MA (2001) Am Mineral 86:66; d: Yakubovich OV, Massa V, Pekov IV, Gavrilenko PG, Chukanov NV (2004) Crystallogr Rpts 49:953; Hochella MFjr, Brown GEjr, Ross FK, Gibbs GV (1979) Am Mineral 64:337

381. a: Bensch W, Schur M (1995) Z Kristallogr 210:530; b: Chakoumakos BC, FernandezBaca JA, Boatner LA (1993) J Solid State Chem 103:105; c: Giester G, Rieck B (1994) Mineral Mag 58:663

382. Artioli G, Rinaldi R, Wilson CC, Zanazzi PF (1995) Acta Cryst B51:733; Sherriff BL, Grundy HD, Hartman JS, Hawthorne FC, Cerny P (1991) Can Mineral 29:271

383. Merlino S (1974) Acta Cryst B30:1262

384. Tazzoli V, Domeneghetti MC, Mazzi F, Cannillo E (1995) Eur J Mineral 7:1339

385. Kahlenberg V, Marler B, Muñoz Acevedo JC, Patarin J (2002) Solid State Sci 4:1285

386. Karpov OG, Pobedimskaya EA, Belov NV (1977) Sov Phys Crystallogr 22:215

387. Schichl H, Völlenkle H, Wittmann A (1973) Mh Chem 104:854

388. Irran E, Köllisch K, Leoni S, Nesper R, Henry PF, Weller MT, Schnick W (2000) Chem Eur J 6:2714 